\title{
The Treatment of the Piano in Six Selected Chamber Works by Colombian Composers in the Twenty-First Century
}

Javier Camacho

Follow this and additional works at: https://researchrepository.wvu.edu/etd

\section{Recommended Citation}

Camacho, Javier, "The Treatment of the Piano in Six Selected Chamber Works by Colombian Composers in the Twenty-First Century" (2017). Graduate Theses, Dissertations, and Problem Reports. 7067.

https://researchrepository.wvu.edu/etd/7067

This Dissertation is protected by copyright and/or related rights. It has been brought to you by the The Research Repository @ WVU with permission from the rights-holder(s). You are free to use this Dissertation in any way that is permitted by the copyright and related rights legislation that applies to your use. For other uses you must obtain permission from the rights-holder(s) directly, unless additional rights are indicated by a Creative Commons license in the record and/ or on the work itself. This Dissertation has been accepted for inclusion in WVU Graduate Theses, Dissertations, and Problem Reports collection by an authorized administrator of The Research Repository @ WVU.

For more information, please contact researchrepository@mail.wvu.edu. 


\title{
THE TREATMENT OF THE PIANO IN SIX SELECTED CHAMBER WORKS BY \\ COLOMBIAN COMPOSERS IN THE TWENTY-FIRST CENTURY
}

\author{
Javier Camacho
}

A Doctoral Research Project submitted to the

College of Creative Arts

at

West Virginia University

In partial fulfillment of the requirements for the degree of

Doctor of Musical Arts

in

Collaborative Piano

\author{
Peter Amstutz, DMA, Chair and Research Advisor \\ Lucy Mauro, DMA \\ William Haller, DMA \\ William Skidmore, MM \\ Jaime Toro, PhD
}

School of Music

Morgantown, West Virginia

2017

Keywords: 1) Colombian music 2) Collaborative piano 3) Chamber music

4) Bambuco 5) Pasillo

두 2017 Javier Camacho 


\section{Abstract \\ The Treatment of the Piano in Six Selected Chamber Works by Colombian Composers in the Twenty-First Century \\ Javier Camacho}

This research project examines selected contemporary chamber-music works with piano by Colombian composers. It describes the different styles, techniques, pianistic elements, and pedagogical approaches present in: Rapsodia (Rhapsody) for clarinet and piano (2000) by Jorge Alejandro Salazar (b. 1978); A la Memoria de 21 Ángeles (In memory of 21 Angels) for trumpet and piano (2014) by Mauricio Arias (b. 1984); Andrómeda for violin and piano (2007) and Scorpius for soprano, violin and piano (2010) by Jorge Humberto Pinzón (b. 1968); Into the Silence for violin, clarinet and piano (2011) by Paola Márquez (b. 1978); and Dospianazo No. 1 (2011) by Germán Darío Pérez (b. 1968). After a brief introduction, the study presents a review of related literature. Chapters two and three are independent: While chapter two, discusses the different resources available in this field, chapter three presents an historical overview of Colombian art music in the $20^{\text {th }}$ and $21^{\text {st }}$ centuries with brief explanations of traditional rhythms and dances that influence most of contemporary Colombian art music. The outline of discussion in each of the remaining chapters features: composer's life, compositional style, list of works, overview of the selected work, and a collaborative pianist's perspective. The works studied in this project encompass a wide variety of styles and techniques, and represent an important source of learning for performers, educators, and musicologists interested in incorporate contemporary Colombian chamber music into the classrooms and concert halls. 


\section{Acknowledgements}

First and foremost, I would like to express my gratitude to the great Colombian composers featured in this document. I am grateful for the support they offered me and for their passion to create new music. I would like to especially thank my wonderful teacher, research advisor, and mentor, Dr. Peter Amstutz for guiding me throughout this process. I would like to recognize my doctoral committee, Dr. Lucy Mauro, Dr. William Haller, Prof. William Skidmore, and Dr. Jaime Toro who encouraged me to explore and share the music of my country. Lastly, I would also like to sincerely thank my family in Colombia for their constant love and support. 


\section{Table of Contents}

$\begin{array}{ll}\text { Abstract } & \text { ii }\end{array}$

$\begin{array}{ll}\text { Acknowledgements } & \text { iii }\end{array}$

List of Musical Examples $\quad$ V

$\begin{array}{lll}\text { Chapter } 1 . \quad \text { Introduction } & 1\end{array}$

$\begin{array}{lll}\text { Chapter 2. } & \text { Review of Related Literature }\end{array}$

Chapter 3. $\quad$ An Overview of Art Music in Colombia: 11

Twentieth and Twenty-First Centuries

$\begin{array}{lll}\text { Chapter 4. } & \text { Jorge Alejandro Salazar } & 19\end{array}$

Rapsodia for clarinet and piano 26

Chapter 5. $\quad$ Mauricio Arias 37

A la memoria de 21 Ángeles for trumpet and piano $\quad 42$

Chapter 6. Jorge Humberto Pinzón $\quad 53$

Andrómeda for violin and piano 61

Scorpius for soprano, violin, and piano 67

$\begin{array}{lll}\text { Chapter 7. } & \text { Paola Márquez } & 72\end{array}$

Into the Silence for violin, clarinet, and piano 78

Chapter 8. $\quad$ Germán Darío Pérez 88

Dospianazo No. 1 for two pianos 96

$\begin{array}{lll}\text { Chapter 9. } & \text { Conclusions } & 107\end{array}$

$\begin{array}{ll}\text { Bibliography } & 110\end{array}$ 


\section{List of Musical Examples}

\section{Examples}

Example 3.1 Germán Darío Pérez, Ancestro (Bambuco), mm. 13-20. 14

Example 3.2 Luis Antonio Calvo, Anhelos (Pasillo), mm. 1-6. 14

Example 3.3 Luis Antonio Calvo, Malvaloca (Danza), mm. 7-13. 15

Example 4.1 Jorge Alejandro Salazar, Rapsodia, opening. 29

Example 4.2 Jorge Alejandro Salazar, Rapsodia, mm. 13-18. 29

Example 4.3 Jorge Alejandro Salazar, Rapsodia, mm. 19-24. 30

Example 4.4 Jorge Alejandro Salazar, Rapsodia, mm. 25-30. 30

Example 4.5 Jorge Alejandro Salazar, Rapsodia, mm. 31-36. 31

Example 4.6 Jorge Alejandro Salazar, Rapsodia, mm. 61.66. 31

Example 4.7 Jorge Alejandro Salazar, Rapsodia, mm. 73-78. 32

Example 4.8 Jorge Alejandro Salazar, Rapsodia, mm. 85-90. 32

Example 4.9 Jorge Alejandro Salazar, Rapsodia, mm. 115-120. 33

Example 4.10 Jorge Alejandro Salazar, Rapsodia, mm. 157-162 33

Example 4.11 Jorge Alejandro Salazar, Rapsodia, mm. 199-210. 34

Example 4.12 Jorge Alejandro Salazar, Rapsodia, mm. 317-330. 35

Example 4.13 Jorge Alejandro Salazar, Rapsodia, mm. 381-392. 36

Example 5.1 Mauricio Arias, A la memoria de 21 Ángeles, mm. 1-6. 46

Example 5.2 Mauricio Arias, A la memoria de 21 Ángeles, mm. 13-18. 46

Example 5.3 Mauricio Arias, A la memoria de 21 Ángeles, mm. 19-24. 47

Example 5.4 Mauricio Arias, A la memoria de 21 Ángeles, mm. 54-58. 47

Example 5.5 Mauricio Arias, A la memoria de 21 Ángeles, mm. 72-78 48 
Example 5.6 Mauricio Arias, A la memoria de 21 Ángeles, mm. 104-109.

Example 5.7 Mauricio Arias, A la memoria de 21 Ángeles, mm. 110-114.

Example 5.8 Mauricio Arias, A la memoria de 21 Ángeles, mm. 152-155.

Example 5.9 Mauricio Arias, A la memoria de 21 Ángeles, mm. 242-251.

Example 5.10 Mauricio Arias, A la memoria de 21 Ángeles, mm. 236-241.

Example 5.11 Mauricio Arias, A la memoria de 21 Ángeles, cadenza.

Example 6.1 Jorge Humberto Pinzón, Andrómeda, mm. 1-6.

Example 6.2 Jorge Humberto Pinzón, Andrómeda, mm. 21-26.

Example 6.3 Jorge Humberto Pinzón, Andrómeda, mm. 44-51.

Example 6.4 Jorge Humberto Pinzón, Andrómeda, mm. 57-58.

Example 6.5 Jorge Humberto Pinzón, Andrómeda, mm. 73-83.

Example 6.6 Jorge Humberto Pinzón. Scorpius, mm. 5-12.

Example 6.7 Jorge Humberto Pinzón. Scorpius, mm. 13-22.

Example 6.8 Jorge Humberto Pinzón. Scorpius, mm. 65-69.

Example 6.9 Jorge Humberto Pinzón. Scorpius, mm. 77-82

Example 7.1 Paola Márquez. Into the Silence, opening.

Example 7.2 Paola Márquez. Into the Silence, mm. 19-23.

Example 7.3 Paola Márquez. Into the Silence, mm. 24-31 82

Example 7.4 Paola Márquez. Into the Silence, mm. 57-62. 83

Example 7.5 Paola Márquez. Into the Silence, mm. 83-92. 84

Example 7.6 Paola Márquez. Into the Silence, mm. 176-183. 85

Example 7.7 Paola Márquez. Into the Silence, mm. 217-221. 86

Example 7.8 Paola Márquez. Into the Silence, mm. 224-228 87 
Example 8.1 Germán Darío Pérez, Dospianazo No. 1, opening. 99

Example 8.2 Germán Darío Pérez, Dospianazo No. 1, mm. 10-12. 100

Example 8.3 Germán Darío Pérez, Dospianazo No. 1, mm. 33-38 101

Example 8.4 Germán Darío Pérez, Dospianazo No. 1, mm. 47-50 102

Example 8.5 Germán Darío Pérez, Dospianazo No. 1, mm. 63-68. 103

Example 8.6 Germán Darío Pérez. Dospianazo No. 1, mm. 81-86 104

Example 8.7 Germán Darío Pérez, Dospianazo No. 1, mm. 99-102. 105

Example 8.8 Germán Darío Pérez, Dospianazo No. 1, mm. 166-168. 105

Example 8.9 Germán Darío Pérez, Dospianazo No. 1, mm. 148-150. 106 


\section{Chapter 1}

\section{Introduction}

This research paper is focused on the significant role of the piano as a collaborative instrument in six selected contemporary chamber-music works by Colombian composers. The aim of this paper is to describe the fascinating variety of pianistic resources and musical styles found in the following pieces:

- "Rapsodia" for clarinet and piano (2000) by Jorge Alejandro Salazar (b. 1978)

- “A la Memoria de 21 Ángeles” for trumpet and piano (2014) by Mauricio Arias (b. 1984)

- “Andrómeda" for violin and piano (2007) by Jorge Humberto Pinzón (b. 1968)

- "Scorpius" for soprano, violin, and piano (2010) by Jorge Humberto Pinzón (b. 1968)

- "Into the Silence" for violin, clarinet, and piano (2010) by Paola Márquez (b. 1978)

- “Dospianazo No. 1” for two pianos (2011) by Germán Darío Pérez (b. 1968)

The music studied in this research project represents a broad spectrum of compositional techniques and it includes duos and trios with voice, strings, woodwinds, and brass instruments. Although the six pieces are each relatively short in length (none of them exceeds ten minutes), their analysis requires a multi-dimensional approach that encompasses historical, stylistic, practical, and pedagogical perspectives.

It is the author's hope that this document can contribute towards explaining the richness and diversity of Colombian art music. Increased understanding can also build cultural bridges and provide the reader, especially the collaborative pianist, with insight 
into a musical repertoire that unfortunately is not well-known outside of Colombia. In addition, this project not only examines the artistic qualities of the pieces from the perspective of the performer, but also encourages the integration of contemporary world music as a powerful pedagogic tool.

As an international student who lives in the United States, the author of this research paper has humbly taken up the role of being an artistic ambassador for his country. He feels the obligation to explore the vast universe of musical and artistic expressions that are present in his culture and then to share them with the world. The beauty and expressive qualities of Colombian contemporary chamber-music works not only represent a fascinating diversity in styles, rhythms, harmonic languages, and forms, but also constitute a formidable source of learning for collaborative pianists and musicians in general. In this regard, Colombian researcher Ana María Orduz rightly states:

Many world music pieces include rhythmical, melodic, and harmonic characteristics not commonly found in European repertoire. Learning these technical tools will broaden the skill set of the student, which they can then use when performing other repertoire. ${ }^{1}$

This project places Colombian composers within the context of the $21^{\text {st }}$ century music scene and highlights their valuable contributions; this needs to be done because, unfortunately, in most cases their work has not been sufficiently recognized or performed outside of Colombia. From a wider perspective, this research paper also encourages the performance and pedagogical utilization of relevant artistic creations from Colombia, while

\footnotetext{
${ }^{1}$ Ana Maria Orduz. "Integrating Contemporary World Music into our Teaching: Discussion on the Pedagogical Value and Performance Practice of Seven Commissioned Pieces by Four Colombian Composers." (D.M.A. essay, The University of Iowa, 2010), 14.
} 
enriching the study and analysis of sources for musicians interested in the diffusion of works like these.

The criteria for selecting the repertoire for this study focused on the search for highly contrasting works and is intended to provide the reader the opportunity to appreciate the artistic richness of Colombian art music, the composers' original musical styles, and their contribution to the chamber music literature in general and the collaborative-piano field in particular. Furthermore, this study presents a practical approach to the works from the collaborative pianist's perspective instead of a dense measure-by-measure theoretical analysis. Also, since the paper is oriented towards highlighting the role of the piano, the fact that the majority of the composers studied here either currently have or have had successful careers as pianists, was crucial in the selection of the pieces.

The research process included finding music scores and recordings of more than fifty Colombian chamber music works with piano composed after 2000, studying the pieces, comparing and contrasting their styles, selecting six of them for detailed study, and analyzing the different pianistic elements in the selected works with an emphasis on performance issues. Each composer is discussed within an individual chapter. The organization of chapters is not chronological, and the order in which the pieces are studied is structured according to different criteria such as character, instrumentation, and length of the piece.

Chapters 2 and 3 are independent: while chapter 2 offers a review of related literature, chapter 3 presents an historical overview of Colombian art music in the $20^{\text {th }}$ and $21^{\text {st }}$ centuries with brief explanations of traditional rhythms and dances. The outline of discussion in each of the remaining chapters features: 1) composer's life, 2) compositional 
style, 3) list of works, 4) overview of the selected work, and 5) a collaborative pianist's perspective.

The sources include scholarly writings and publications in Spanish and in English, video and audio recordings, documentaries, and interviews with the selected composers. At different stages of his life, the author of this research paper has had the privilege to work closely with most of the composers and performers that have premiered, recorded, and performed this music. This close connection with them has allowed him to have access to personal scores, documents, and informal conversations which complemented the research methodology. 


\section{Chapter 2}

\section{Review of Related Literature}

The topic of this research project is unique because it combines two broad areas of interest for performers, educators, and musicologists: First, the importance of the piano as a collaborative instrument and, second, the integration of diverse pianistic resources into the musical language of contemporary Colombian chamber-music repertoire.

In recent years, and more specifically since the creation of the first doctoral degree in accompanying in the United States at the University of Southern California (1969), the expressions "collaborative piano," or "collaborative pianist" (coined by American pianist Samuel Sanders) have been used more frequently in order to emphasize the significant role of the piano in the chamber-music literature and the importance of balancing the roles of all the instruments as equal partners in these kinds of works. ${ }^{2}$

In one of the most complete research documents that explore the art of collaboration, "Donald Nold and his Contribution to the Emergence of Collaborative Piano," American researcher Katherine Sundstrom concludes that:

Collaborative pianists are creative artists with the musicianship and unique sound of solo artists. What qualifies them as collaborators is their desire to merge their high-level artistry with those of other artists, in order to reap the mutual rewards of collaboration. Characterized by a drive to collaborate, a hunger to learn repertoire, and a commitment to shared success, they possess a high-level knowledge of tradition, a sensitive and artistic ear for ensemble, the ability to coach and guide fellow artists, a familiarity with an expanse of

\footnotetext{
${ }^{2}$ Pei Shan Lee. "The Collaborative Pianist: Balancing Roles in Partnership." (D.M.A. diss., New England Conservatory of Music, 2009).
} 
repertory, the sensitivity to work successfully in a cooperative environment, and the ability to play musically that which was not composed for the piano. ${ }^{3}$

The role of a collaborative pianist is broadly discussed throughout the twelve chapters of the celebrated book The Complete Collaborator, published in 2009 by American pianist Martin Katz. ${ }^{4}$ Several other researchers have included this topic in their publications as well. That is the case for Dr. Dian Baker, who wrote an extensive resource manual which includes a categorized list of works worth studying by an aspiring collaborative pianist. ${ }^{5}$ Dr. Pei Shan Lee has studied collaborative piano curriculums and has interviewed leaders in the collaborative field, providing an interesting overview of those programs in the United States in her research paper called "The Collaborative Pianist: Balancing Roles in Partnership."6

The writings of Dr. Lauralie Bel Pow discuss the importance of musical analysis and analytical techniques as an important resource for collaborative pianists. In her doctoral essay "More than Mere Notes: Incorporating analytical skills into the Collaborative Pianist's Process in Learning, Rehearsing and Performing Repertoire," she demonstrates

\footnotetext{
${ }^{3}$ Katherine Sundstrom. "Donald Nold and His Contribution to the Emergence of Collaborative Piano." (M.M. thesis, The William Paterson University of New Jersey, 2016), 41-42.

${ }^{4}$ Martin Katz. The Complete Collaborator: The Pianist as Partner. (Oxford University Press, 2009).

${ }^{5}$ Dian Baker. "A Resource Manual for the Collaborative Pianist: Twenty Class Syllabi for Teaching Collaborative Piano Skills and an Annotated Bibliography." (D.M.A. diss., Arizona State University, 2006).

${ }^{6}$ Pei Shan Lee. "The Collaborative Pianist: Balancing Roles in Partnership.” (D.M.A. diss., New England Conservatory of Music, 2009).
} 
that the knowledge of analytical concepts is crucial for understanding different interpretive options hidden in the music. ${ }^{7}$

The above-mentioned writings, along with other similar books, publications, and research documents, constitute an important source of information on how the vision of the piano as a part of an ensemble has changed in the past half-century. However, the importance of contemporary Colombian chamber music repertoire as a learning tool for collaborative pianists has scarcely been taken into consideration to date.

It is true that the history of contemporary Colombian art music is not a linear process that can be traced easily in time and space. Therefore, bibliographical sources available on this topic seem to be incomplete, fragmentary and sometimes unbalanced; a significant portion of them are also written in Spanish. In fact, it can be frustrating to observe that while certain composers, subgenres or pieces have been profusely studied, others have been considered only tangentially or simply ignored.

In addition, since most of the works studied in this research project have been composed in recent years, and most of them have not been even published yet, it is not surprising that the availability of resources related to this topic is fairly limited. However, an exhaustive search on online databases such as ProQuest, Jstor, and WorldCat has revealed the existence of a small but important set of publications and musicological research documents that examine Colombian art music.

\footnotetext{
${ }^{7}$ Lauralie Bell Pow. "'More than the Mere Notes': Incorporating Analytical Skills into the Collaborative Pianist's Process in Learning, Rehearsing, and Performing Repertoire." (D.M.A. essay, University of Miami, 2016).
} 
The best available sources related to this topic are theses, dissertations, research papers, essays, articles and blog posts. With only a few exceptions, the existing writings are mainly focused on individual pieces, specific instruments, particular composers, influences of popular and folk-music, or distinctive styles. Apart from a few documents that offer a general overview of the history of Colombian music, the majority of references provide more specialized musical contents.

Perhaps one of the most significant bibliographical resources available in English which examines the confluence of contemporary Colombian music and piano pedagogy is the doctoral essay "Integrating Contemporary World Music into Our Teaching: Discussion on the Pedagogical Value and Performance Practice of Seven Commissioned Pieces by Four Colombian Composers," by Dr. Ana María Orduz. Her work is an original and revealing document which articulates through eight chapters, aspects of performance, piano pedagogy, influences of folk-music, and composition of new Colombian music by emerging composers. ${ }^{8}$ A similar work that is worth mentioning is "Colombian Piano Music for Four Hands: A Historical Context and Performance Catalog,” by Dr. Diego Arango, which explores the history and significance of Colombian piano music for piano duet. ${ }^{9}$

The life and works of Jorge Humberto Pinzón are explored by Colombian researcher Paula Viviam Rodríguez throughout three well organized chapters in her monograph “Vida y Obra del Maestro Jorge Humberto Pinzón Malagón,” published

\footnotetext{
${ }^{8}$ Ana Maria Orduz. "Integrating Contemporary World Music into our Teaching: Discussion on the Pedagogical Value and Performance Practice of Seven Commissioned Pieces by Four Colombian Composers." (D.M.A. essay, The University of Iowa, 2010).

${ }^{9}$ Diego Arango. "Colombian Piano Music for Four Hands: A Historical Context and Performance Catalog." (D.M.A. essay, The University of Iowa, 2013).
} 
recently in Bogotá. ${ }^{10}$ A reference to this composer and specifically to his piece "Mobile para Fagot y Piano" is also present in the sixth chapter of a concise research project called "A Portrayal of Colombian Art Music in Colombia through four Works for Bassoon," by Dr. Lia Southern. ${ }^{11}$

The musical style of the pianist, composer, and improviser Mauricio Arias is studied in a revealing two-part research paper written by the composer himself during his doctoral studies at Arizona State University: "Rapsodia Camaleónica: A Concerto for Piano, Trumpet and Chamber Orchestra," in which the composer discusses the different compositional aspects of this work, including instrumentation, form, influences, and performer's perspective. $^{12}$

Since composer and pianist Germán Darío Pérez is one of the most important voices representing the confluences of both popular and academic styles, his work can be understood through research papers related to the development of traditional ColombianAndean rhythms such as bambuco and pasillo. Academic writing on this topic includes several documents. Two of the most complete studies are: "Exploring Three ColombianAndean Folk Style (Danza, Pasillo, and Bambuco): An Analysis and Arrangement of Three Colombian Pieces for Flute and Piano," by Dr. Jesús Castro Turriago; ${ }^{13}$ and an extensive

\footnotetext{
${ }^{10}$ Paula Rodríguez-Moreno. "Vida y Obra del Maestro Jorge Humberto Pinzón Malagón” (B.M. monograph, Fundación Universitaria Juan N. Corpas, 2016).

${ }^{11}$ Lia Southern. "A Portrayal of Art Music in Colombia through Four Works for Bassoon." (D.M.A. diss., University of Kansas, 2013).

${ }^{12}$ Mauricio Arias-Esguerra. "Rapsodia Camaleónica: A Concerto for Piano, Trumpet and Chamber Orchestra." (D.M.A. paper, Arizona State University, 2012).

${ }^{13}$ Jesus Castro Turriago. "Exploring Three Colombian-Andean Folk Style (Danza, Pasillo, and Bambuco): An Analysis and Arrangement of Three Colombian Pieces for Flute and Piano." (D.M.A. diss., The University of Southern Mississippi, 2016).
} 
doctoral dissertation completed in the 1970s by Dr. Dirk Koorn: "Folk Music of The

Colombian Andes." Both of these works trace the main characteristics and significance of Colombian folk music. ${ }^{14}$

It is important to consider the existence of research documents about other influential Colombian composers that have not been included in this paper. Composers Jaime León, Blas Emilio Atehortúa, and Luis Antonio Escobar for example, have been objects of extensive research and writings by Dr. Elissa Álvarez, ${ }^{15}$ musicologist Victoria Sofía Botero, ${ }^{16}$ Dr. Pamela Bowen Chester, ${ }^{17}$ and Dr. Julián Gómez-Giraldo. ${ }^{18}$

Interestingly, for the present research, the limited number of bibliographical resources is compensated for by the existence of invaluable documents such as recordings (made or supervised by the composers themselves), and also by interviews and documentaries available on the internet.

\footnotetext{
${ }^{14}$ Dirk Koorn. "Folk Music of the Colombian Andes." (D.M.A diss., University of Washington, 1977).

${ }^{15}$ Elissa Alvarez. "Pride, Place, and Identity: Jaime León's Transcontinental Exploration of Identity through Art Song." (D.M.A. diss., Boston University, 2013).

${ }^{16}$ Victoria Botero. "The Art Songs of Jaime León: A Textual and Musical Analysis." (M.M. thesis, University of Missouri, 2011).

${ }^{17}$ Pamela Chester. "A Study of the Life and Wind Music of Blas Emilio Atehortua, Including a Critical Edition and Stylistic Analysis of "Cinco Piezas a Bela Bartok" (D.A. diss., University of Northern Colorado, 1997).

${ }^{18}$ Julian Gomez-Giraldo. "Analytical and Performance Approach of "Danzas En El Sentimiento Andino" by Luis Antonio Escobar. (D.M.A. diss., University of Northern Colorado, 2013).
} 


\section{Chapter 3}

\section{An Overview of Art Music in Colombia: Twentieth and Twenty-First Centuries}

The Republic of Colombia is located in the northwest of South America. It encompasses an area of 440,831 square miles, and has an estimated population size on the order of 49 million individuals. The country shares borders with Panamá, Venezuela, Brazil, Ecuador, and Perú. The particular topography of Colombia divides the country into six main regions: the Atlantic coast (north), the Pacific coast (west), the Andean region (center), the Eastern plains (east), the Colombian Amazon (south), and the Insular region (islands in both the Atlantic and Pacific oceans).

Historically, and especially after gaining independence from Spanish colonial rule in 1819, complex interactions between different ethnic groups in Colombia (Amerindian, Spanish, and sub-Saharan African) have played a fundamental role in the intricate process of defining the country's own cultural identity. This identity could be best described as a conglomeration of diverse manifestations joined together by a powerful exchange of artistic, intellectual and linguistic features.

Unquestionably, in the $20^{\text {th }}$ century, the creation of art music in Colombia and in Latin America in general, received the direct influence from both autochthonous and European styles of composition. As pointed out by Colombian researcher Mónica Tobo:

Different European practices and musical trends have permeated Latin American music for over five hundred years, most of which almost always have been assimilated a bit late in the subcontinent. ${ }^{19}$

\footnotetext{
${ }^{19}$ Mónica Tobo. "Una Aproximación a la Obra para Piano de Mario Gómez-Vignes.” trans. Javier Camacho. (Universidad Pedagógica y Tecnológica de Colombia, 2008): 4.
} 
In the case of Colombia, the search for a "national accent" was the main focus of discussion for most composers in the first decades of the $20^{\text {th }}$ century. The creation of the Academia de Música in the capital city of Bogotá, in 1882 (later called Conservatorio de Música de Bogotá), was determinant in this early stage of development of a national style of composition. Colombian researcher Jesús Castro explains:

In 1910 Guillermo Uribe Holguín was elected as the Director of the Academia [de Música in Bogotá]. Uribe Holguín restructured the musical policies of the conservatory, removing any aspect related to Colombian popular music from the curriculum [...] Due to these reforms, a continuous dialectic process, held mostly in the capital of the country between 1920 and 1936, regarding the policies that should guide the development of the musical education in the country began. This dialectic process was held between two opposing cultural groups: Nationalists vs. Traditionalists. Nationalists believed in the use and promotion of folk music to develop a national cultural identity, while Traditionalists believed that Colombian musical education should be taught and developed under the European musical education system. ${ }^{20}$

Although these particular confrontations faded after 1935, several composers

continued to experiment with a mixture of styles, exemplified not only by the preference for small forms and the supremacy of salon pieces for piano (in the manner of the European character pieces), but also by the integration of traditional elements into their compositions. In fact, the richness and suitability of traditional dances from the Andean region such as bambuco, pasillo, and danza, constituted an important source for composers regardless of their particular positions. Emilio Murillo (1880-1942), Antonio María Valencia (1904-1952), Guillermo Uribe Holguín (1880-1971), Daniel Zamudio (18851952), and Luis Antonio Calvo (1882-1945) are among the most celebrated composers of this time period in Colombia.

\footnotetext{
${ }^{20}$ Jesus Castro Turriago. "Exploring Three Colombian-Andean Folk Style (Danza, Pasillo, and Bambuco): An Analysis and Arrangement of Three Colombian Pieces for Flute and Piano." (D.M.A. diss., The University of Southern Mississippi, 2016).
} 
With the exception of the danza, all the above-mentioned dances of the Colombian Andean region have rhythmic elements in common. Basically they are in a moderate $3 / 4$ rhythm with cross rhythm of $6 / 8$ such that it is not easily identifiable whether the rhythms are duple or triple. Differences in the accompaniment and melodic rhythmic patterns serve to distinguish one dance from another.

According to Dr. Dirk Koorn, bambuco is the most important and representative musical form of the Colombian Andes. It is usually characterized by a binary form in which there is often a key change for the second part. Instrumental introductions and interludes often separate the two parts. It is syncopated, but there are differences of opinion as to where, in a 3/4 measure, the syncopation comes. Somewhere in the accompaniment there is an empty beat. That is, one of the six eighth notes in the measure is emphasized by its absence, sounding only five, and one "accented" rest. ${ }^{21}$

Perhaps the most captivating characteristic of the bambuco is its rhythmic ambiguity (see Example 3.1). The definition of bambuco in the Grove Music Online goes further and explains that:

In the bambuco the syncopations involve crossing the rhythms (3/4 against $6 / 8$ ), and the absence of an accented note on the accented part of the measure. Although bambucos are written in simple triple meter (3/4) the rhythmic effects are felt as two-against-three polymetric pull, more easily conceived of in 6/8 metre. The disjunct two-against-three feel is common throughout Latin America and is referred to by musicologists as sesquialtera. ${ }^{22}$

\footnotetext{
${ }^{21}$ Dirk Koorn. "Folk Music of the Colombian Andes." (D.M.A diss., University of Washington, 1977). 90.

${ }^{22}$ Gerard Béhague, et al. "Colombia." Grove Music Online. Oxford Music Online. Oxford University Press, accessed March 29, 2017, http://www.oxfordmusiconline.com/subscriber/article/grove/music/06137.
} 
Example 3.1. Germán Darío Pérez, Ancestro (Bambuco), mm. 13-20.
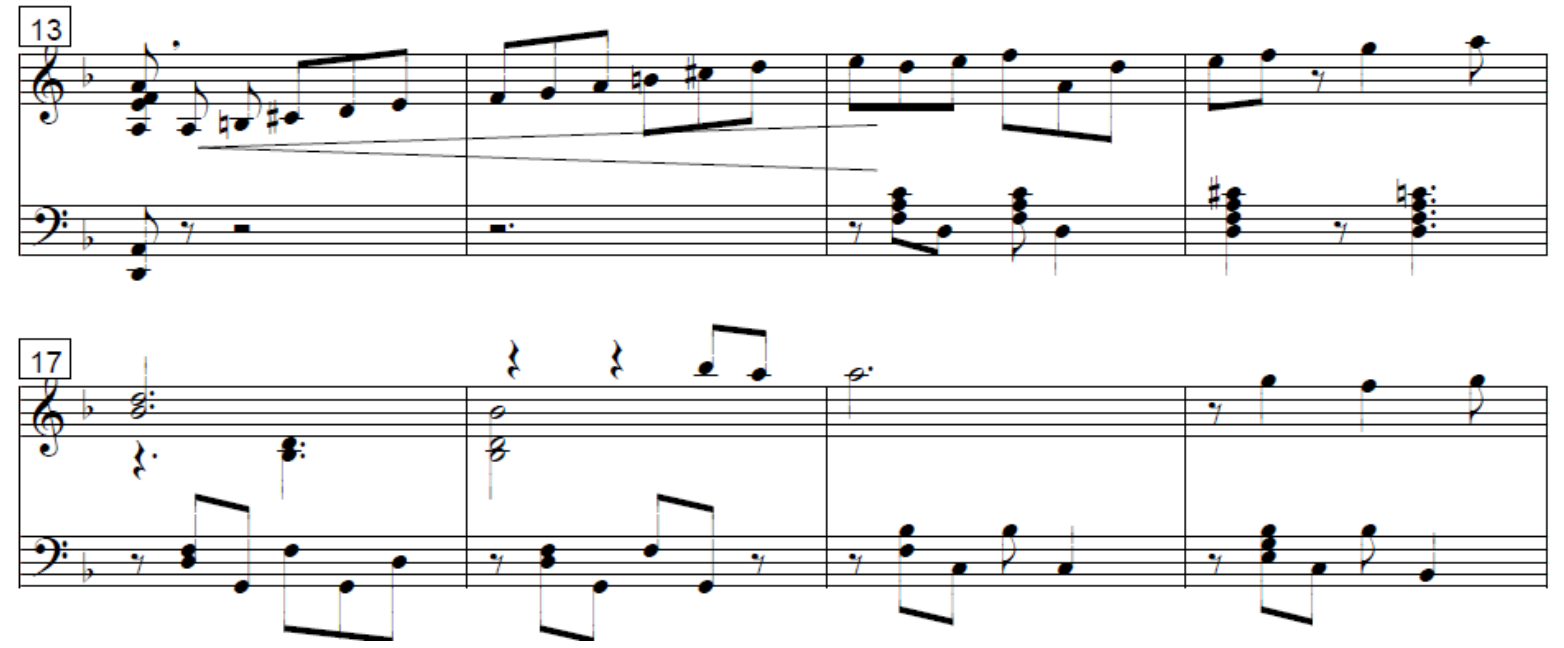

The pasillo is closely related to the bambuco, although its origin is European. It descended from the Austrian waltz, and it was cultivated during the colonial period as a formal ballroom dance (see Example 3.2). There are two variants: the slow or vocal pasillo, and the very fast or instrumental pasillo which is characterized by a rondo form, syncopated melodies, and horizontal and vertical polyrhythmic effects.

Example 3.2. Luis Antonio Calvo, Anhelos (Pasillo), mm. 1-6.

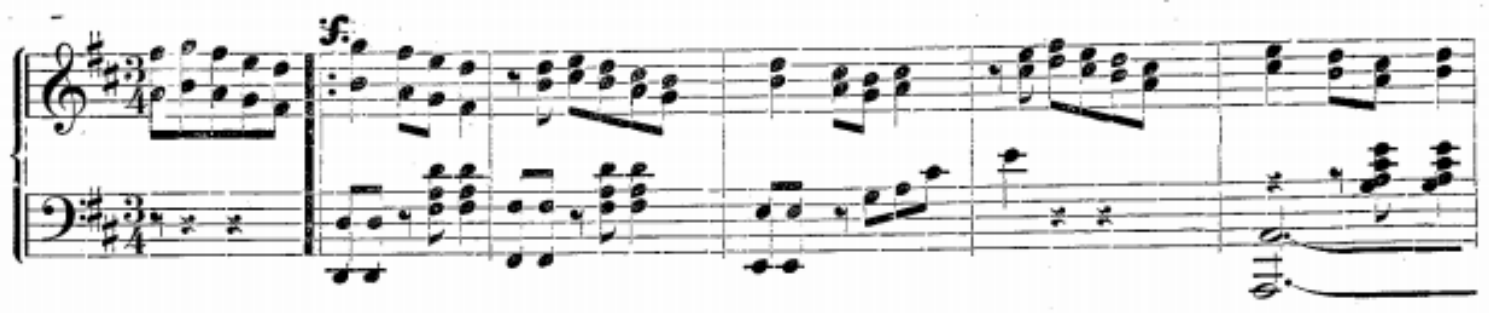

The danza, which came to Colombia from Europe by way of Cuba, is rhythmically identical to the habanera (see Example 3.3). This is the only dance of the Andean region which is in duple meter (often notated in 2/4). It is predominantly in a slow tempo. ${ }^{23}$

\footnotetext{
${ }^{23}$ Koorn. Folk Music of the Colombian Andes, 178.
} 
Example 3.3. Luis Antonio Calvo, Malvaloca (Danza), mm. 7-13.

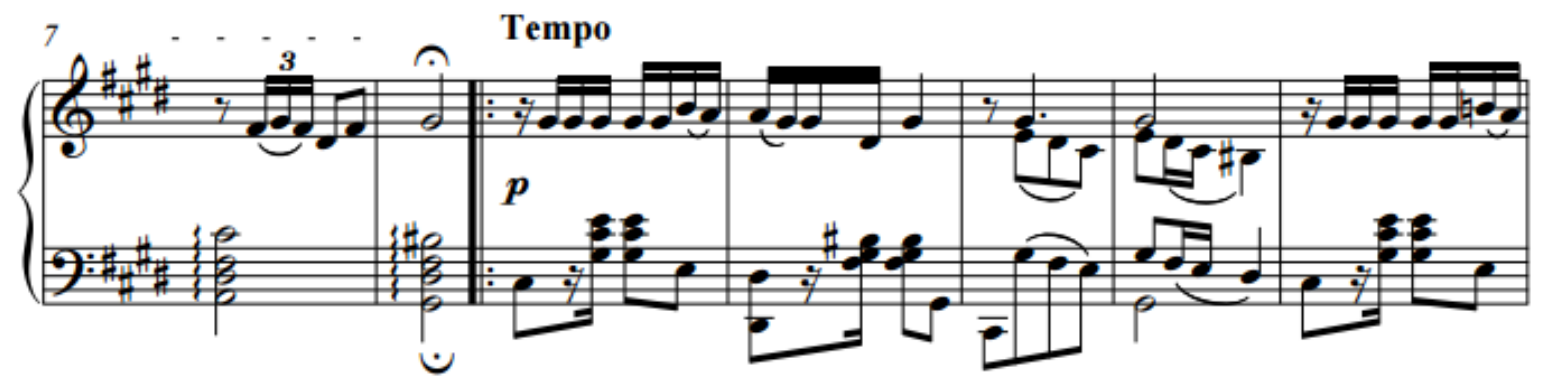

Evidently, Colombian-Andean dances themselves are "hybrid" forms. In art-music, compositions for traditional ensembles of guitar, bandola, requinto, and tiple (all of them Creole chordophone instruments descended from the Spanish guitar) were frequently adapted to the piano. The use of popular tunes as the source of inspiration had already set a precedent, but it was clear that the harmonies originated from the European romantic style. Therefore, the work of most Colombian composers became a bridge between a $19^{\text {th }}$ century European musical aesthetic and a strong distinctive folkloric tradition.

There ensued an exaltation of national values, a strengthening of patriotism. The resurgence of national consciousness pushed musicians, visual artists, and writers in an effort to find themselves within their own realities. The culture served as an important tool in the establishing of this self-identity.

Undoubtedly, the attempt to preserve pure Latin American art was a main concern in the period between 1920 and 1940, as a folkloric, nationalistic current spread throughout the entire continent, with pretensions of universality, even if that was not always achieved. The most widespread result was the acquisition of European trends, such as impressionism, expressionism, and neoclassicism, with the use of nationalistic images. During this time, it became evident that the measures to preserve pure Latin 
American art consisted of producing an art characteristic of each region to show what could be offered as a contribution to "universal music."

However, World War II began in the midst of that process and stopped it for years. The inherited conditions after the end of World War II did not substantially change the economic and social realities of the continent. In music, however, the war opened new doors for experimentation and cosmopolitan creativity. After the war, Colombian composers who studied in Europe began to assimilate into their music the new compositional techniques and stylistic tendencies beginning to appear in European music. All Latin American countries turned to the search for new materials and timbric resources with new research tools and new techniques of composition.

Colombia asserted itself as an integral part of this process as well; during the mid-1940s, when nationalism began to wane, composers began to look for new, more cosmopolitan elements, which enabled experimentation and fusion of compositional devices that proved more consistent with the modern world. Dr. Lia Southern states that:

Starting in the middle of the $20^{\text {th }}$ century, Colombian composers began searching for a modern and autonomous language that was not romantic or nationalistic in a European sense. That search allowed composers to create individual, and often Colombian, expression by borrowing themes and structures of traditional Colombian music while maintaining a style that aligned them with the compositions of their contemporaries. This period represents the establishment of a true school of composing in Colombia. ${ }^{24}$

\footnotetext{
${ }^{24}$ Lia Southern. "A Portrayal of Art Music in Colombia through Four Works for Bassoon." (D.M.A. diss., University of Kansas, 2013): 12.
} 
This hybridity was characterized by the embodiment of certain European trends. These trends include: Neoclassicism, tonal vagueness, polytonality, twelvetone serialism, and electronic music. After 1955, the music moved increasingly from traditional melody and harmony toward greater rhythmic complexity. For this reason, Colombian composers exhibited an increasing interest in percussion instruments. Composer Andrés Posada justifies this shift in Colombian music:

An artist or musician is not loyal to a single culture. Much less to the arbitrary concept of the borders of a nation... His cultural world is always different from others (though it has elements in common with many others); it is the mixture of elements from various cultures. ${ }^{25}$

Amid this stage of experimentation, new elements and forms were derived from new European trends. Composers of great importance such as Fabio González Zuleta (b. 1920), Jaime León (1921-2005), Luis Antonio Escobar (1925-1993), Jesús Pinzón Urrea (b. 1928), Mario Gómez-Vignes (b. 1932), and Blas Emilio Atehortúa (b. 1943) emerged in Colombia. Works by these composers are characterized by a marked diversity in musical language.

In the last two decades of the $20^{\text {th }}$ century, several institutions of music education with strong composition programs, along with music festivals, symphony orchestras, and new concert halls, started to spread across the country. The role of these institutions, along with an easier and faster access to new technologies, allowed more Colombian composers to study, travel abroad, enrich their styles, and present their works to larger audiences.

\footnotetext{
${ }^{25}$ Andrés Posada. "La Proyección de la Nueva Música en América Latina: Globalización y Periferia.” trans. Javier Camacho. Artes la revista. 5, no. 9 (2005): 21.
} 
Dr. Lia Southern states that:

Today there are more than twenty institutions that offer bachelor's degrees in music; some of these institutions offer master's degrees. This is significant because, on one hand, we have a growing number of performers in constant contact with Colombian composers and their music, which assists in the dissemination of contemporary works. Additionally, the exchanging of ideas with music historians, theorists, performers, and educators allows for these composers to broaden their artistic worldview. ${ }^{26}$

The vast majority of contemporary Colombian composers have had the opportunity to study in prestigious conservatories and universities in Europe and the United States. That is the case of Guillermo Gaviria (b. 1951), Andrés Posada (b. 1954), Juan Antonio Cuéllar (b. 1966), Diego Vega (b. 1968), Jorge Humberto Pinzón (b. 1968), Alba Fernanda Triana (b. 1969), Johann Hasler (b. 1972), Paola Márquez (b. 1978), and Mauricio Arias (b. 1984), among many others.

These composers do not belong to any particular school. Their compositional style is heavily influenced not only by the works of European and American composers, but also by typical folkloric Colombian music (especially from that of the Andean region). When they decide to include traditional elements, they do it as a way to achieve a distinctive Colombian "flavor." Their music displays melodic coherence, clear forms, strong structures, highly developed and varied motivic cells, and very colorful palettes. In terms of compositional techniques, it could be asserted that their work is eclectic because they draw from a vast array of genres without limitation, depending on the requirements of the works.

\footnotetext{
${ }^{26}$ Southern, A Portrayal of Art Music in Colombia through Four Works for Bassoon,17.
} 


\title{
Chapter 4
}

\section{Jorge Alejandro Salazar}

\author{
Life
}

Conductor, composer, and educator Jorge Alejandro Salazar was born in Santa Rosa de Cabal, Risaralda, in 1978. He has achieved recognition not only as one of the leading orchestral and choral conductors in the present Colombian musical scene, but also as one of the most talented composers and pedagogues of his generation. Since the beginning of his career, Salazar has shown a particular interest in collaborating with young musicians through his work in schools, universities, and other educational projects of international relevance. $^{27}$

A passionate and multi-faceted musician, Salazar began his formal training in piano performance and music pedagogy in Tunja, Boyacá at the Escuela Superior de Música de Tunja. His teachers there included Jorge Zorro Sánchez and renowned Colombian pianist and educator Pilar Leyva, a pupil of Claudio Arrau. During the time he spent in Tunja, Salazar also became interested in saxophone, choral conducting, voice performance, and composition while combining all of his academic activities with sporadic participations as a pianist in salsa (an urban popular dance genre developed in New York City and Puerto Rico during the 1960s and 70s, based on Cuban dance styles and incorporating Puerto Rican elements and influences from jazz and rock) ${ }^{28}$ and Latin jazz music ensembles.

\footnotetext{
27 "Un día en la Vida de... Jorge Alejandro Salazar (UniCorpas TV - Capítulo 1)," YouTube video, 23:55, posted by "UniCorpas TV," April 19, 2012. https://www.youtube.com/watch?v=eABlxinQPvI

${ }^{28}$ Lise Waxer. "Salsa." Grove Music Online. Oxford Music Online. Oxford University Press, accessed March 31, 2017, http://www.oxfordmusiconline.com/subscriber/article/grove/music/24410.
} 
After completion of his Bachelor of Music degree in 2000, he moved to Bogotá to pursue graduate studies in orchestral conducting at Universidad Antonio Nariño under the guidance of maestro Luis Eduardo Vargas. In 2003, Salazar was appointed as Director of Orchestral and Choral Activities at Fundación Universitaria Juan N. Corpas in Bogotá, and also as Artistic Director and Pedagogue of the Corporación Orquestal y Coral de Colombia, a position that allowed him to work closely with young music students in different regions of the country. Over the following years, he had the opportunity to conduct in Argentina, Chile, Venezuela, United States, and Russia, and to appear in master classes, festivals, and workshops with world-renowned artists such as: Gustavo Dudamel, Andrés OrozcoEstrada, Simon Carrington, Luis Gorelik, Helmut Rilling, María Guinand, and Alberto Grau. $^{29}$

He has worked with the majority of professional and student orchestras in his country, such as: Orquesta Filarmónica de Bogotá, Orquesta Sinfónica de Colombia, Orquesta Filarmónica de Cali, Orquesta Sinfónica de Antioquia, Orquesta Sinfónica de EAFIT, Orquesta Sinfónica Juvenil de Medellín, Orquesta Sinfónica del Conservatorio del Tolima, Orquesta Sinfónica Juvenil de Medellín, among others.

Prize-winner at several national orchestra conducting competitions, Salazar won three silver medals as the conductor of the Coro de Cámara de la Fundación Universitaria Juan N. Corpas at the Seventh World Choir Games in Cincinnati, Ohio in 2012, and was finalist of the Orchestra International Conducting Competition in Cadaqués, Spain in 2013. In the same year he participated as one of the organizers of the Festival América Cantat 7 in Bogotá, where he conducted the world premiere of the Cantata América by Spanish

\footnotetext{
29 “Música,” Juan N. Corpas, accessed April 02, 2017, http://www.juanncorpas.edu.co/ofertaacademica/pregrado/musica/orquesta-sinfonica/.
} 
composer José Buenagu (b. 1935), and his own Canción por la Esperanza for choir and orchestra. Recently, in 2015 Salazar completed his Master of Music degree in Orchestral Conducting at the Universidad Nacional de Colombia, under the tutelage of internationally acclaimed maestro Guerassim Voronkov.

Perhaps one of the most fascinating aspects of his life is his ability to combine his performance activities with his work as a pedagogue. As professor of orchestral conducting at Fundación Universitaria Juan N. Corpas in Bogotá, Salazar has taught and mentored several members of the new generation of Colombian orchestra conductors. Some of them already have successful international careers or are currently studying at world-class institutions. Former students include: Lina Marcela González, doctoral student in orchestra conducting at Boston University and Artistic Director of the Unitas Ensemble; ${ }^{30}$ Carlos Ágreda, 2016-2017 Conducting Fellow at Curtis Institute of Music in Philadelphia; Paola Ávila, Master of Music student in orchestra conducting at the Peabody Conservatory of Music, Johns Hopkins University; and María Camila Barbosa, who recently made her orchestra conducting debut at the prestigious Cartagena International Music Festival in Cartagena, Colombia. ${ }^{31}$

Throughout his career, Salazar has maintained a particular interest in the field of music composition as well. Although his catalog of works is not extensive, their high quality has been recognized. As a matter of fact, he was been awarded first prize in the Concurso Distrital de Composición Coral para el Proyecto 40x40 in Bogotá, for two consecutive years (2015-2016) with his Canciones para Coro Infantil y Juvenil. Also in

\footnotetext{
${ }^{30}$ An ensemble founded in Boston in 2014, specialized in performances of Latin American works.

${ }^{31}$ NoticiasRCN, "María Camila Barbosa, la directora de orquesta más joven del Cartagena XI Festival Internacional de Música," Noticias RCN, January 11, 2017, accessed April 02, 2017, http://www.noticiasrcn.com/videos/maria-camila-barbosa-directora-orquesta-mas-joven-del-cartagena-xifestival-internacional.
} 
Bogotá, he received second prize at the National Competition of Composition for Choir and Chamber Ensemble in 2016 with El Renacuajo Paseador, a collection of ten pieces for SATB choir, clarinet, piano, double bass, and percussion on the tale of Colombian writer Rafael Pombo (1833-1912). 


\section{Compositional Style}

Jorge Alejandro Salazar's style of composition clearly exemplifies one of the main characteristics of Colombian art music in the $21^{\text {st }}$ century: The use of a hybrid language which reveals the he has absorbed a wide array of influences which range from nineteenthcentury European composers to Colombian-Andean folk traditional music, and even salsa and jazz. Both the popular and the academic are represented in his writing. Thus, in concordance with the wide variety of styles that are present in his compositions, perhaps the best way to describe his music is that it exhibits a perfect coexistence of diverse musical elements. It is evident in his works that he could be considered to be "eclectic."

Apart from theory and counterpoint classes in the early stages of his career, Salazar did not have formal training in composition. Perhaps as a result, there is a "spontaneous" quality that has permeated his music and has made it adaptable, flexible, convincing, and appealing for performers and audiences in Colombia and abroad. The main characteristics of his compositional approach are: Clear structures, tonal harmonic language enriched with chromaticism, short melodies that recur in ornamented and varied shapes, sudden tempo changes, and driving rhythms full of syncopations.

His first three works were composed between 2000 and 2002, and after a hiatus of nine years, in which he was dedicated to his many commitments as a conductor and as a pedagogue, he resumed composing with more avidity after 2011. In the vast majority of his pieces, regardless of the instrumentation he has used, Salazar exploits the rhythmic, melodic and harmonic qualities of traditional Colombian music, combining them with an interesting manipulation of textures and colors. Although after the completion of his undergraduate studies in Tunja he decided not to pursue a career as a concert pianist, his 
intense pianistic training during those years allowed him to achieve an idiomatic writing for the instrument.

Through his career, he has demonstrated a profound passion for choral music. His close collaboration with choirs and specifically with Venezuelan composer and conductor Alberto Grau (b. 1937) in several educational projects may have influenced his decision to write profusely for this kind of ensemble. In fact, it is not surprising that $75 \%$ of his completed works are compositions designed for different types of choral ensembles, either accompanied or unaccompanied. 


\section{List of Works}

- Rapsodia for clarinet and piano (2000)

- Tarantella for piano solo (2001)

- Cumbia de mi Tierra for SATB choir (2002)

- Canto a la Luna for SATB choir (2011)

- Étnica - Poema Sinfónico for full orchestra (2012)

- Canción por la Esperanza for full orchestra, SATB choir, children's choir, and soloists (2013)

- Cinco Canciones (Yo tenía un tiple / En la mañana / Agua ven / Tú no eres un mote / Baílalo Así) for children’s and youth choirs (2014)

- Cinco Canciones (El Pintor / Calavera Calaverita / Chucu-Chucu / Cojitas / Canción de Cuna) for children's and youth choirs (2015)

- Amor de Tierra - Bambuco for SATB choir (2016)

- Río for youth choir (2016)

- Dulce Navidad - Suite Colombiana for youth choir (2016)

- El Renacuajo Paseador - 10 pequeñas piezas for STAB choir, clarinet, piano, and percussion on the tale by Rafael Pombo (2016). 


\section{"Rapsodia para Clarinete y Piano"}

An Overview of the Work and a Collaborative Pianist's Perspective

The Rapsodia para Clarinete y Piano (Rhapsody for Clarinet and Piano) was composed in 2000, and is dedicated to two Colombian musicians: Clarinetist Fredy Pinzón and pianist Raúl Mesa, both of them fellow students at the Escuela Superior de Música de Tunja. Written in a single movement with different sections of varying tempos, an average performance of the piece takes between eight and nine minutes approximately.

The duo premiered the piece in September 2002 in a recital at the Iglesia de San Ignacio, in Tunja, Boyacá as part of the annual Festival Internacional de la Cultura. After its premiere, the work has been performed at important venues, including the PNC Recital Hall in Pittsburgh by clarinetist José Gómez and pianist Raúl Mesa (2009). The work was recorded by the original dedicatees in 2013 and was included, along with other works for clarinet and piano, in the album Contrastes, released in Colombia in $2016 .^{32}$ The score of the piece has not been commercially published yet.

The use of the word "Rhapsody" in the title not only describes the loose structure of the piece, but also expresses a veiled allusion to Debussy's fascinating treatment of both instruments in his celebrated Première Rhapsodie (1909-10), a cornerstone of the chambermusic repertoire.

Throughout his work, Salazar combines rhythmic elements present in the traditional music from the Colombian-Andean region (especially pasillo and bambuco), with a harmonic language influenced by jazz and academic European music from the late $19^{\text {th }}$ century. The versatility and technical possibilities of the clarinet are exploited in full,

\footnotetext{
${ }^{32}$ Dúo Debussy.Contrastes, Secretaría de Cultura y Turismo de Tunja, 2016, CD.
} 
especially through a highly chromatic melodic construction. The structure of the piece is based on thematic variation and transformation. Different presentations of the main thematic material recur, alternating with small episodes that work as short developments.

It is true that the organization of the work is neither symmetrical nor proportional. However, this intentional lack of balance is compensated for by a well-defined textural, rhythmic, and harmonic plan. Thus, flexibility of the structure allows the audience to focus the attention on the striking virtuosity of the writing, the challenging rhythmic transitions, and the Colombian national "flavor" of the main thematic ideas.

Undoubtedly, the work is the result of the young composer's interesting experiments with forms and multi-stylistic writing. In fact, the rhapsody exemplifies Salazar's characteristic fusion of two trends: The strictness of the academic and the spontaneity of the popular. The overall character of the piece, with the exotic dances and with the predominance of fast and energetic tempos for most of the episodes, captures the listener immediately.

The composer's pianistic background allows him to incorporate a wide variety of elements in his piano writing. During his undergraduate years in Tunja, Salazar had the opportunity to study and perform the challenging etudes by Chopin and Liszt, as well as other virtuosic pieces like Liszt's Mephisto Waltz No. 1, among others. He was also familiar with the piano patterns of salsa and Latin jazz. Therefore, besides all the rhythmic irregularities, the Rhapsody also incorporates technical difficulties for the pianist such as: Fast scales and arpeggios, chromatic scales, octaves, fast jumps, repeated notes, sudden dynamic changes, trills, grace notes, and glissandos. Perhaps one of the most interesting features of this piece is the articulation indication which consists of two notes marked 
staccato, but grouped under slurs. This articulation is intended to imitate the original chordophone used in the traditional music of the Colombian-Andean region. The correct interpretation of this unusual articulation (separated notes with a little resonance in between) is crucial for understanding the rhythmic complexities of the work.

The piece represents an extraordinary learning tool for the collaborative pianist. The study of its various pianistic elements and ensemble challenges will expand the horizons of the pianist as an ensemble leader and will test his ability to blend his sound with the sound of the clarinet, an instrument which is used frequently in Colombian music. Since the texture of the piano part is thick and uses the extreme registers of the piano, another fundamental aspect for a successful performance is the balance of all the chords and voices. This is important, especially in the moments when the clarinet plays in the low register.

The mysterious repeated ostinato figure at the beginning ( $\mathrm{mm} .1-2)$, gives the pianist the responsibility of establishing the enigmatic character of the piece. The entrance of the clarinet with a characteristic syncopation in $\mathrm{m} .5$ announces a pasillo; however the composer skillfully writes the figuration in a way that if the clarinet rhythm is heard simultaneously with the pattern of the piano, the result could be perceived as a shortened bambuco rhythm as well (see Example 4.1). 
Example 4.1. Jorge Alejandro Salazar, Rapsodia para Clarinete y Piano, opening.

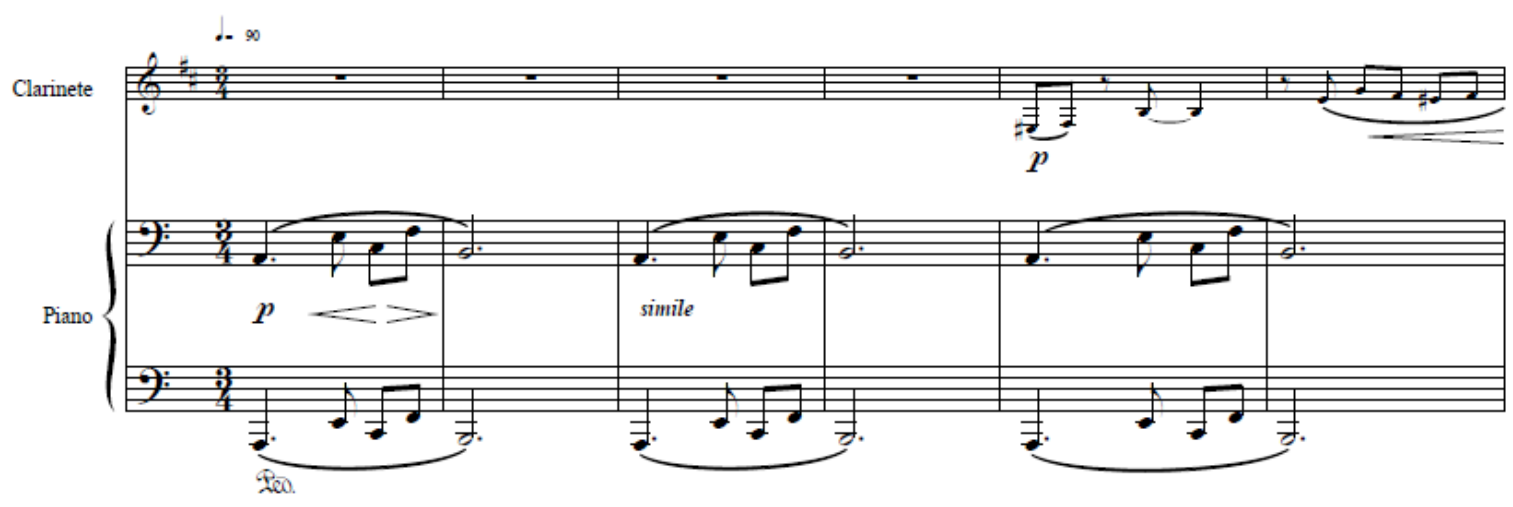

The piano takes a more active role in measure 11 when the accompanying figure incorporates the syncopation in the right hand with a particular articulation of two notes with staccato dots, but slurred at the same time. This accompaniment serves as the harmonic support for the virtuosic figuration of the clarinet (see Example 4.2).

Example 4.2. Jorge Alejandro Salazar, Rapsodia para Clarinete y Piano, mm. 13-18.

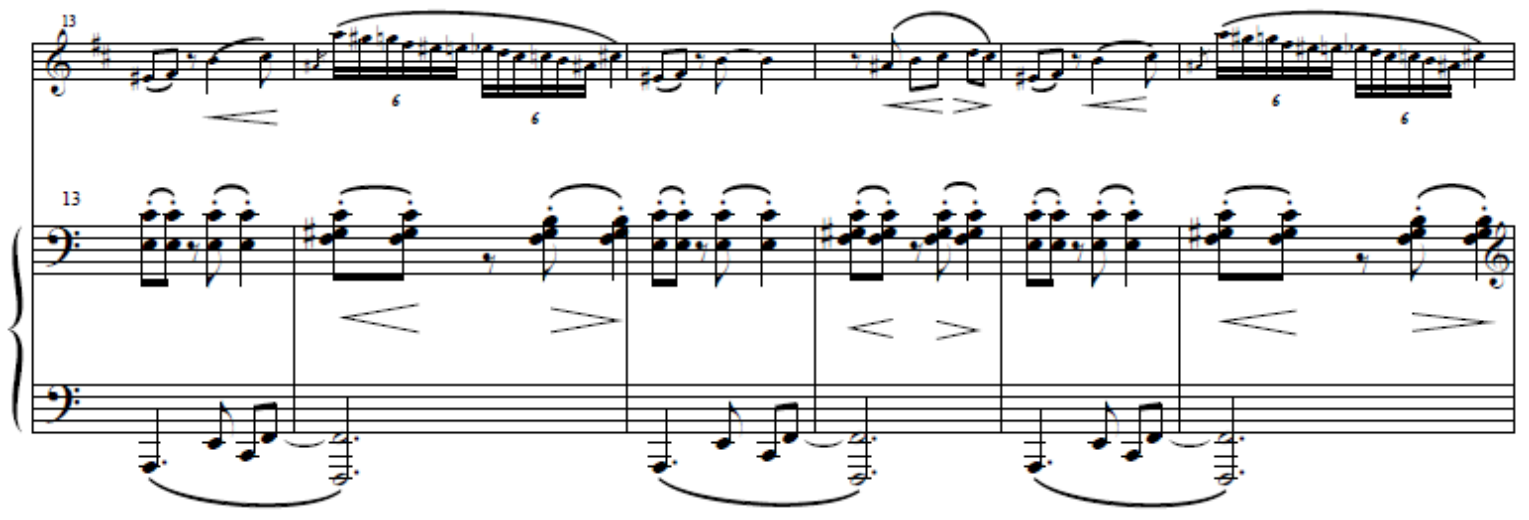

A new figuration of pasillo appears in measure 19 in the left hand with octaves and jumps, and the juxtaposition of fast triplets and sextuplets in the right hand with eight notes in the left hand with a subsequent $f f$ syncopation in the left hand. This rhythmic variety in the very first page of music requires maximum attention from the pianist (see Example 4.3). 
Example 4.3. Jorge Alejandro Salazar, Rapsodia para Clarinete y Piano, mm. 19-24.

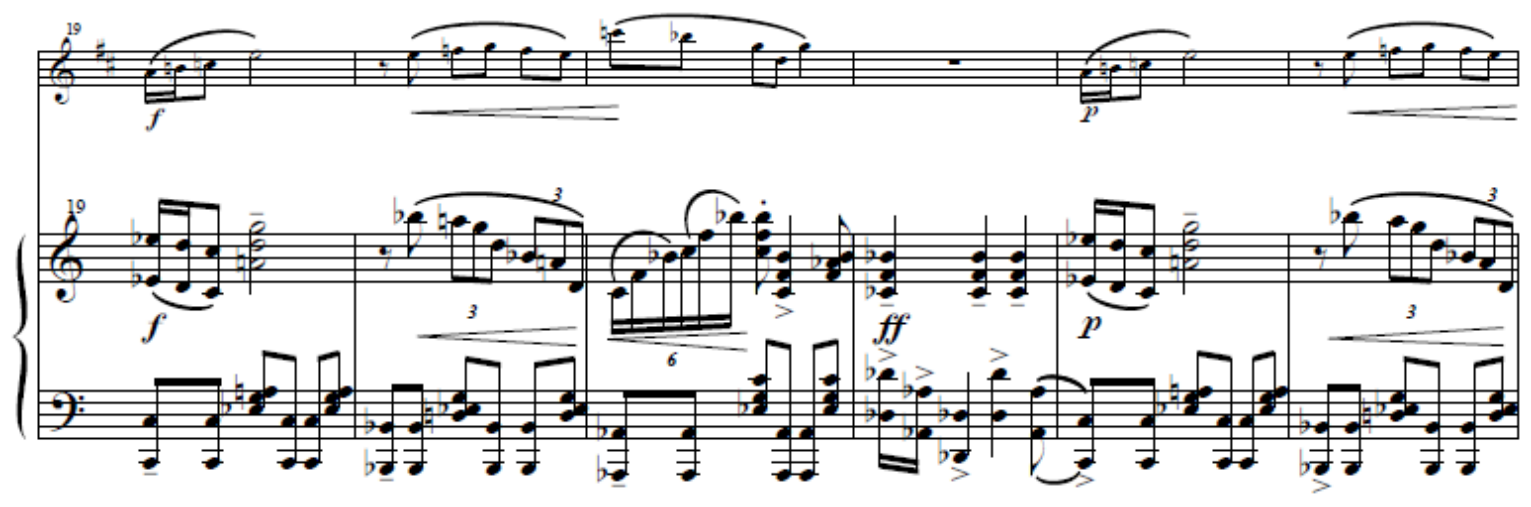

In measure 27, the piano takes the main theme with legato octaves in a ff line marked "passionato," while keeping the ostinato opening motive in the left hand. The clarinet is in charge of a scherzoso ornamentation which will be repeated by the piano later in the piece (see Example 4.4)

Example 4.4. Jorge Alejandro Salazar, Rapsodia para Clarinete y Piano, mm. 25-30.

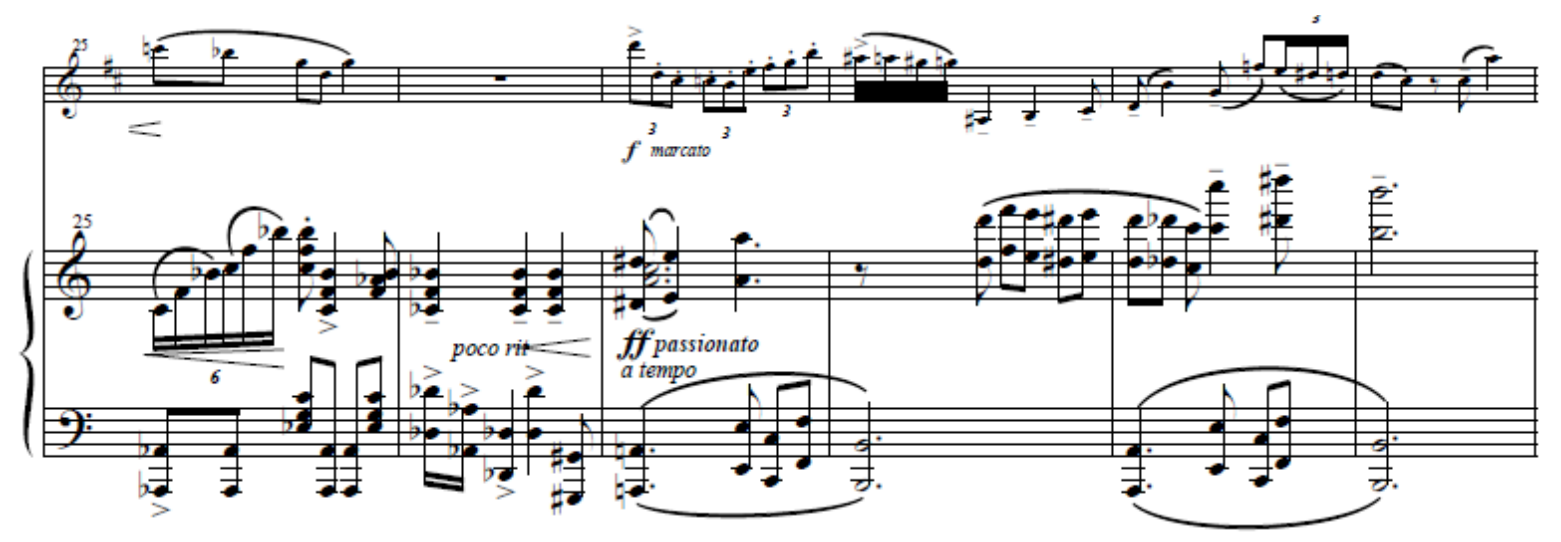

A sudden tempo change modifies the character of the introductory section in measure 33 , introducing a fast pasillo figuration which alternates $6 / 8$ and $3 / 4$. The accents in the left hand are derived from the opening motive and represent a variant of the pasillo accompaniment pattern. Observing the eighth rests in the melody (also present in the 
clarinet) as breathing impulses for the syncopations, so characteristic of these rhythms, is very important (see Example 4.5).

Example 4.5. Jorge Alejandro Salazar, Rapsodia para Clarinete y Piano, mm. 31-36.

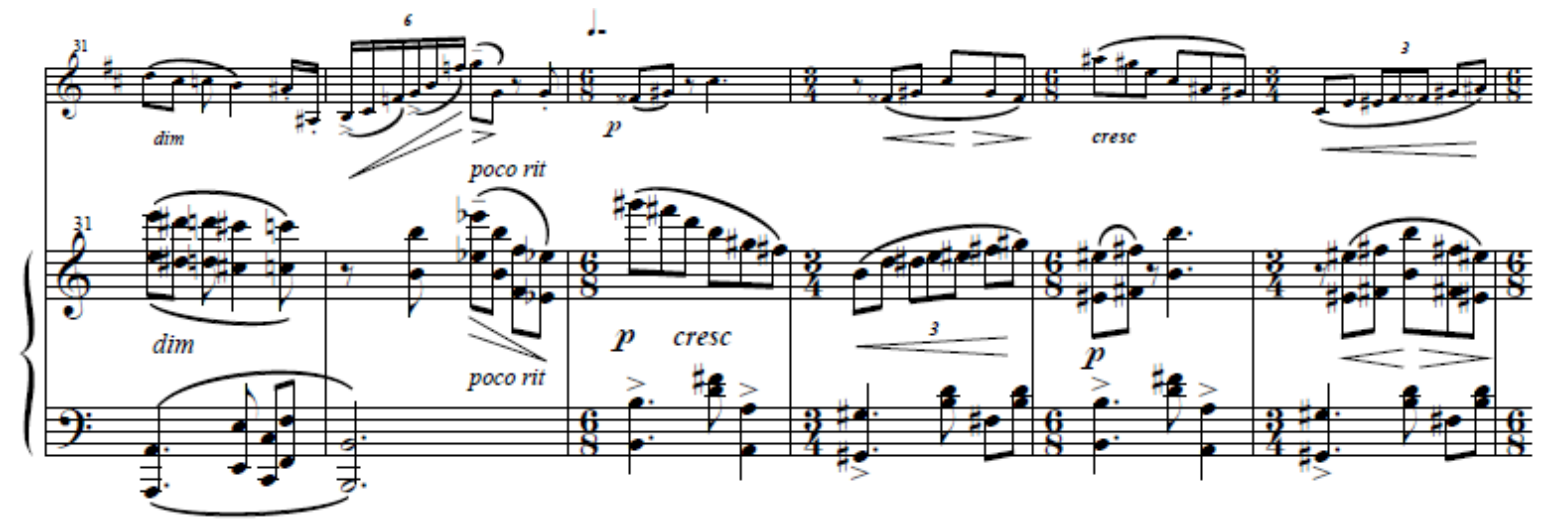

The pianist must be aware of polyrhythmic elements and syncopations, and also should observe the displacements of the accents in the clarinet (alternating accents in the second, first, and third beats. From m. 47 on, the waltz-like melody and accompaniment in the piano work as the rhythmic basis of the section, but two extra difficulties are added by the composer here: Hand crossings and displaced accents in the clarinet (see Example 4.6).

Example 4.6. Jorge Alejandro Salazar, Rapsodia para Clarinete y Piano, mm. 61.66.

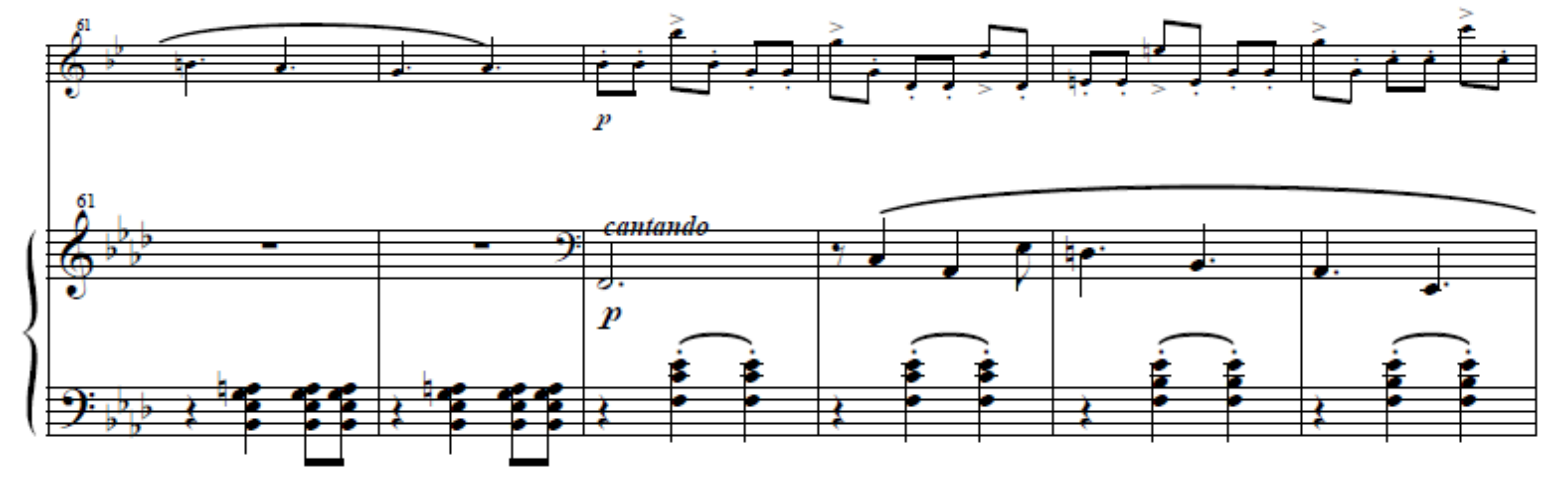


Another relevant element for the pianist is that the piano is often is charge of continuing the melodic lines of the clarinet; in these cases the piano should match the phrase shaping of the clarinet (mm. 75-76) (see Example 4.7).

Example 4.7. Jorge Alejandro Salazar, Rapsodia para Clarinete y Piano, mm. 73-78.

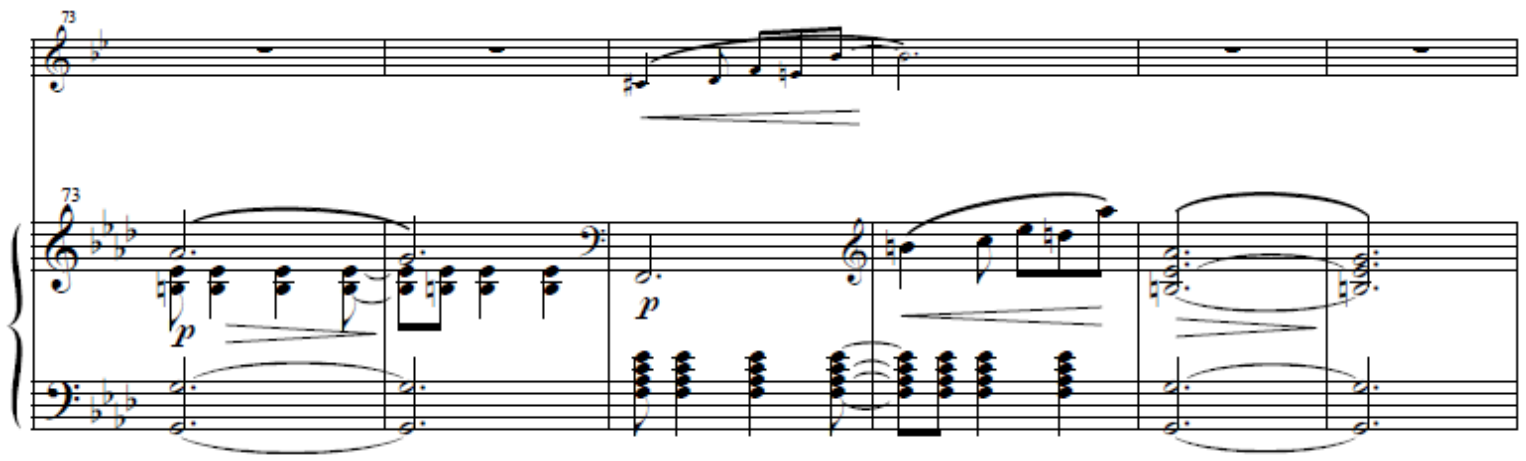

Since the figuration of the right hand in $\mathrm{m} .85$ is clearly related to the clarinet part in m. 27, the articulation and the character must match. This is one of the reasons why the collaborative pianist has to know in detail the clarinet part and respond immediately with a consistent interpretation of similar passages (see Example 4.8).

Example 4.8. Jorge Alejandro Salazar, Rapsodia para Clarinete y Piano, mm. 85-90.

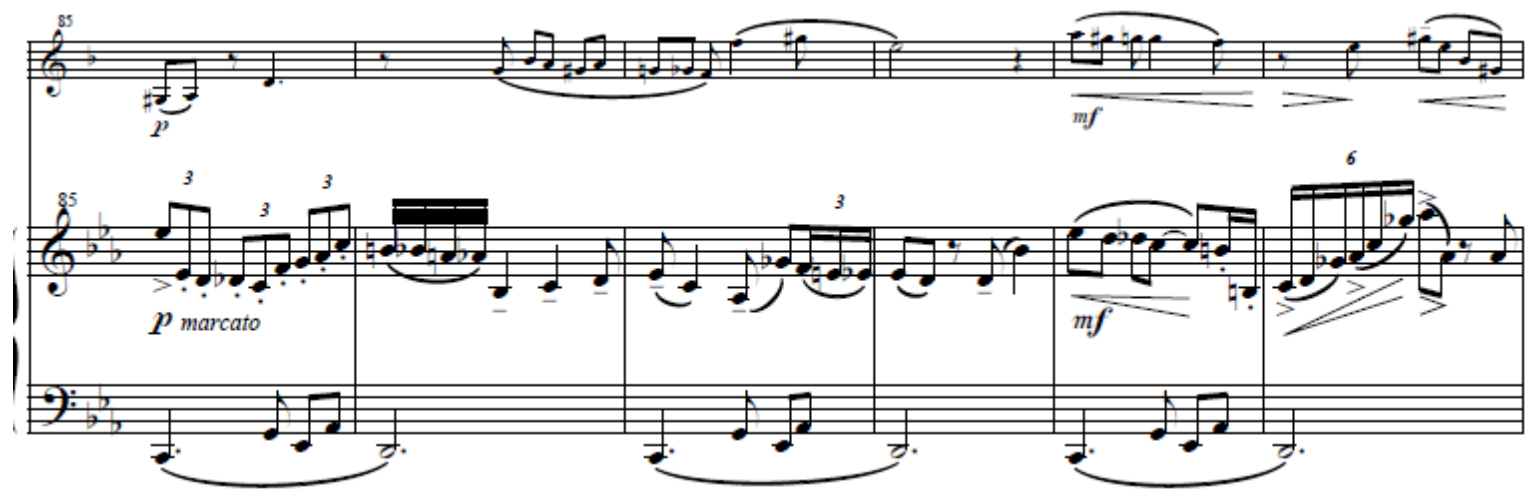


The main theme of the clarinet (mm. 5-10) reappears in measure 115 . This time, the piano transforms the music into a fast and imposing bambuco by presenting the traditional accompaniment pattern of this dance in both hands (see Example 4.9).

Example 4.9. Jorge Alejandro Salazar, Rapsodia para Clarinete y Piano, mm. 115-120.

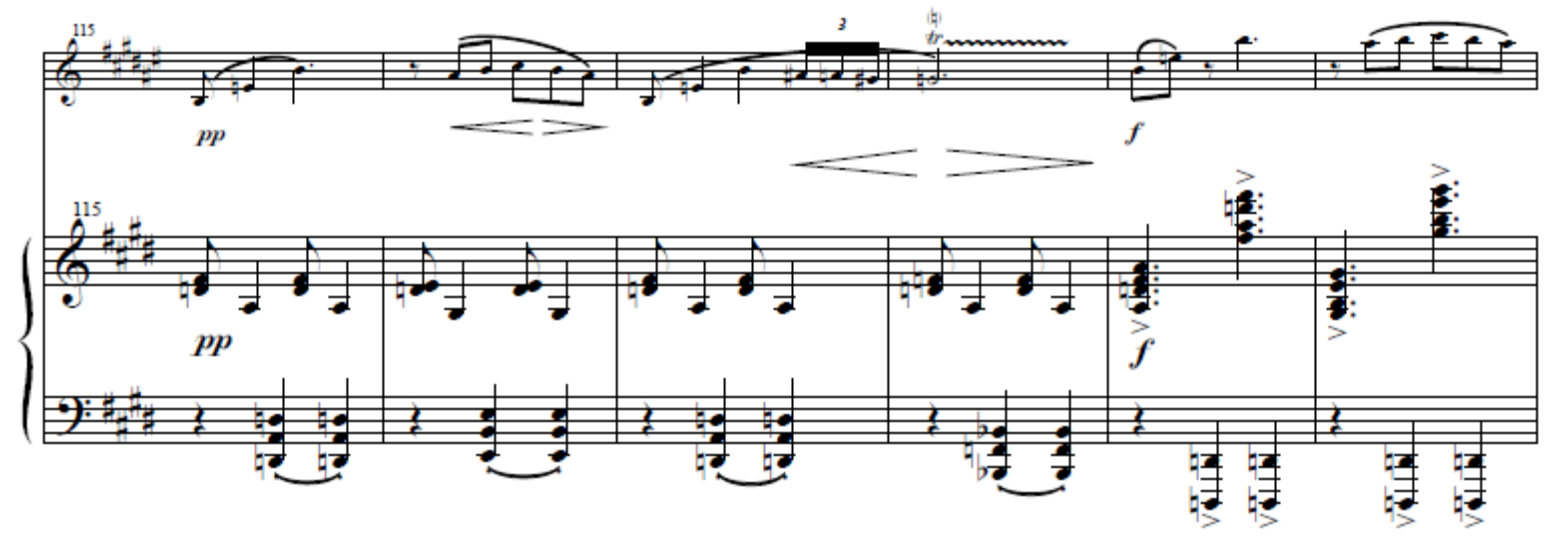

Fast octaves, marked sffz con forza, are one of the technical challenges of this piece (mm. 107-114). Other example of technical difficulties include repeated notes marked $p$ molto staccato e leggiero (mm. 153-160), which again are derived from the clarinet figuration of mm. 145-152, juxtaposed with fast staccato jumps in the left hand (see Example 4.10).

Example 4.10. Jorge Alejandro Salazar, Rapsodia para Clarinete y Piano, mm. 157-162.

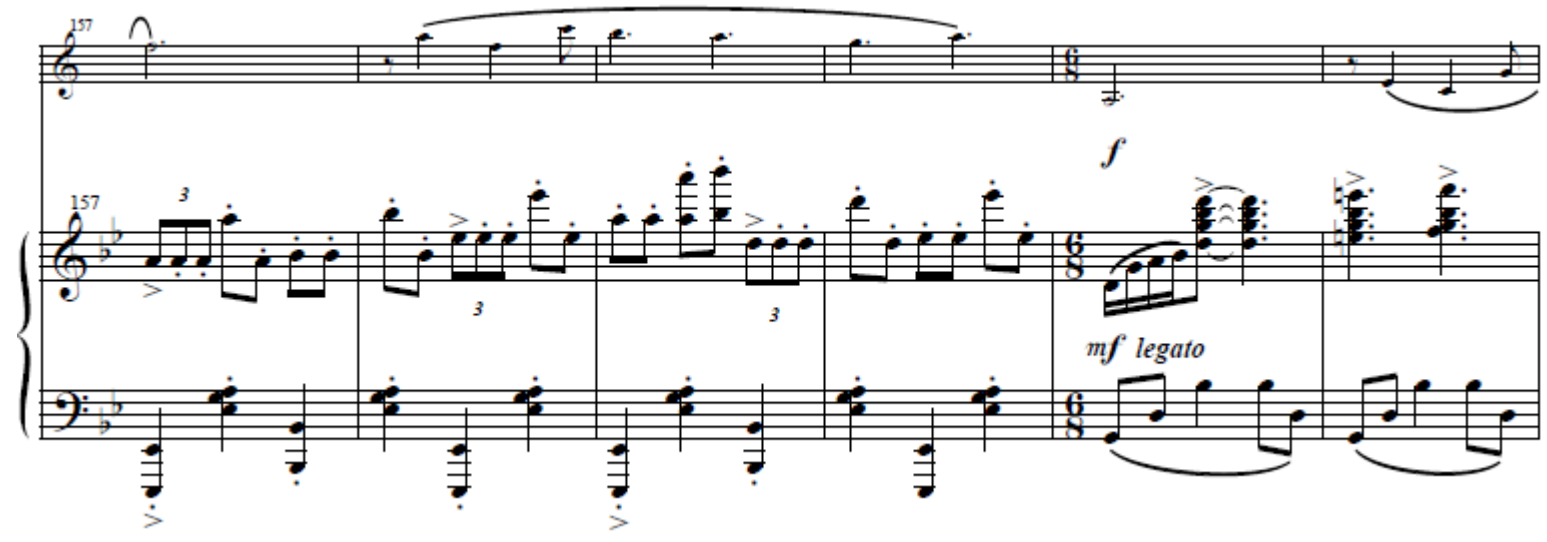


One of the characteristics of the clarinet is its facility to function in the scherzando character. In the piano, this effect is more difficult to achieve. The scherzoso sections need careful attention to the pedaling and a crisp sound in the grace notes (mm. 203-215, 221224, 229-230, 235-236) (see Example 4.11).

Example 4.11. Jorge Alejandro Salazar, Rapsodia para Clarinete y Piano, mm. 199-210.
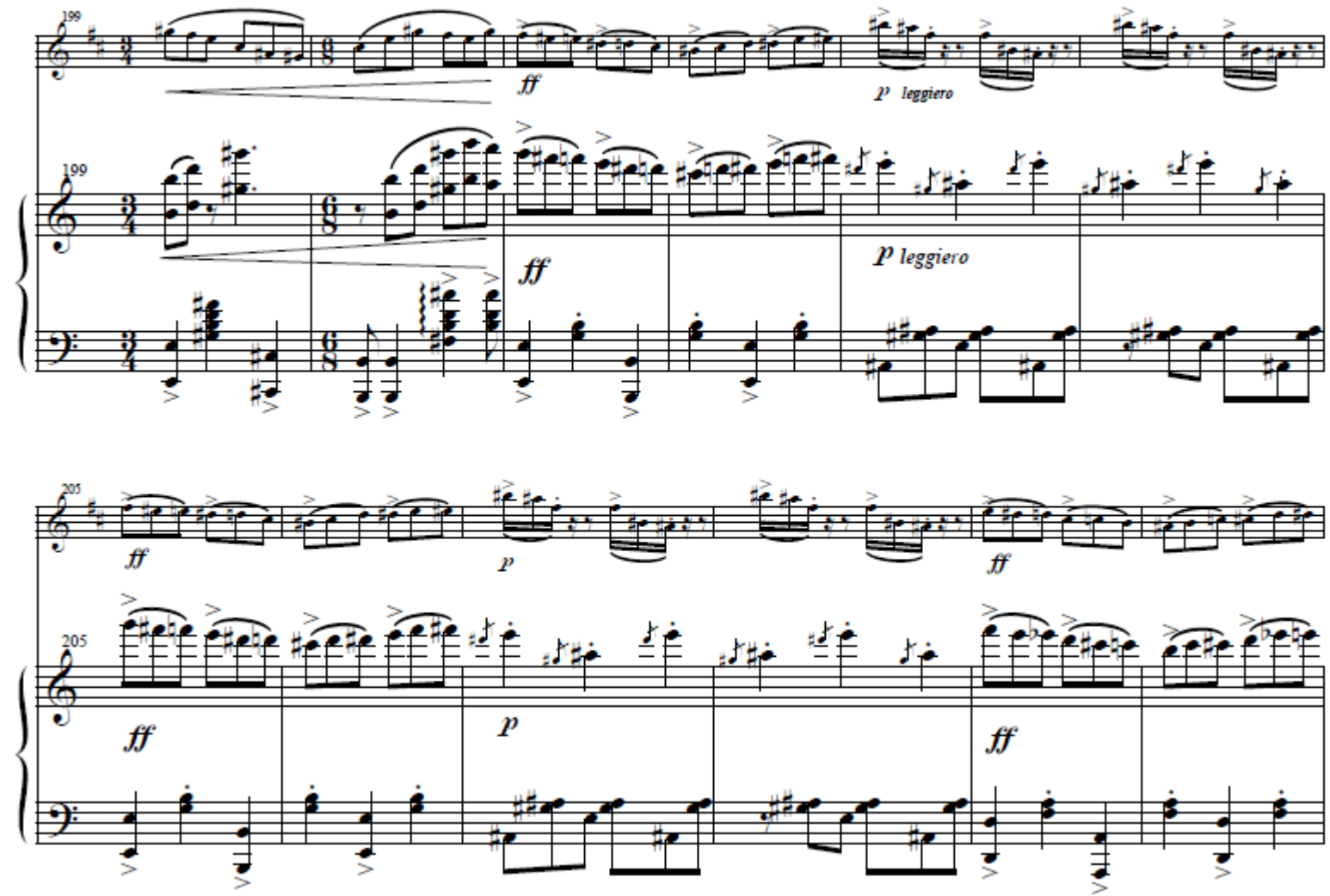

As discussed above, displaced accents are one of the challenges of this piece.

Measures 317-324 constitute a perfect example of this difficulty. Not only is the piano part demanding on its own, but putting it together with the syncopated rhythms of the melody in the clarinet part could also be very difficult (mm. 325-332) (see Example 4.12). 
Example 4.12. Jorge Alejandro Salazar, Rapsodia para Clarinete y Piano, mm. 317-330.
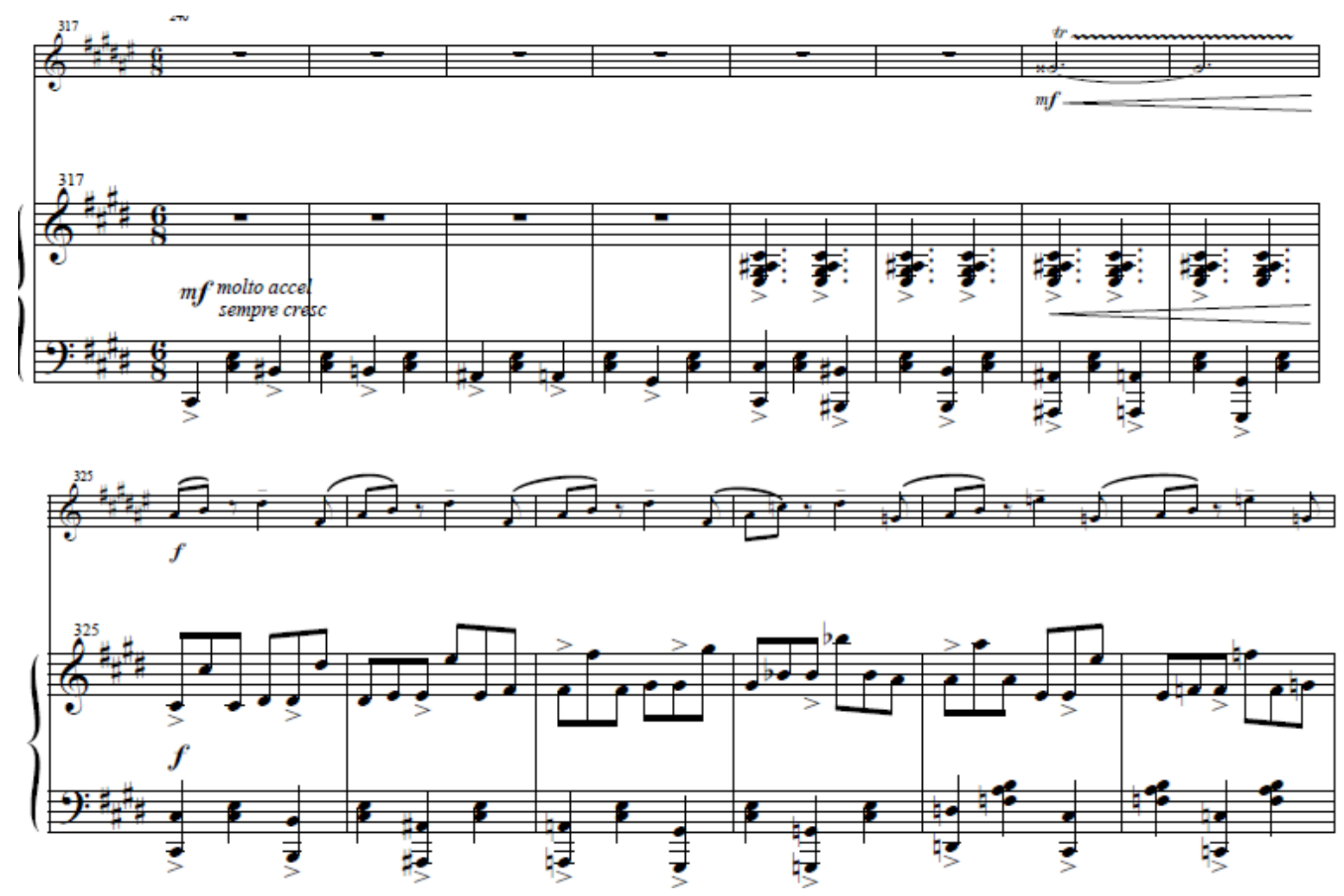

A virtuosic Lisztian style of writing is found in the coda (mm. 317-392) with quick jumps, difficult figuration and fast contrary motion of the hands in octaves with grouping and slurring in triplets and accents in every beat (see Example 4.13). 
Example 4.13. Jorge Alejandro Salazar, Rapsodia para Clarinete y Piano, mm. 381-392.
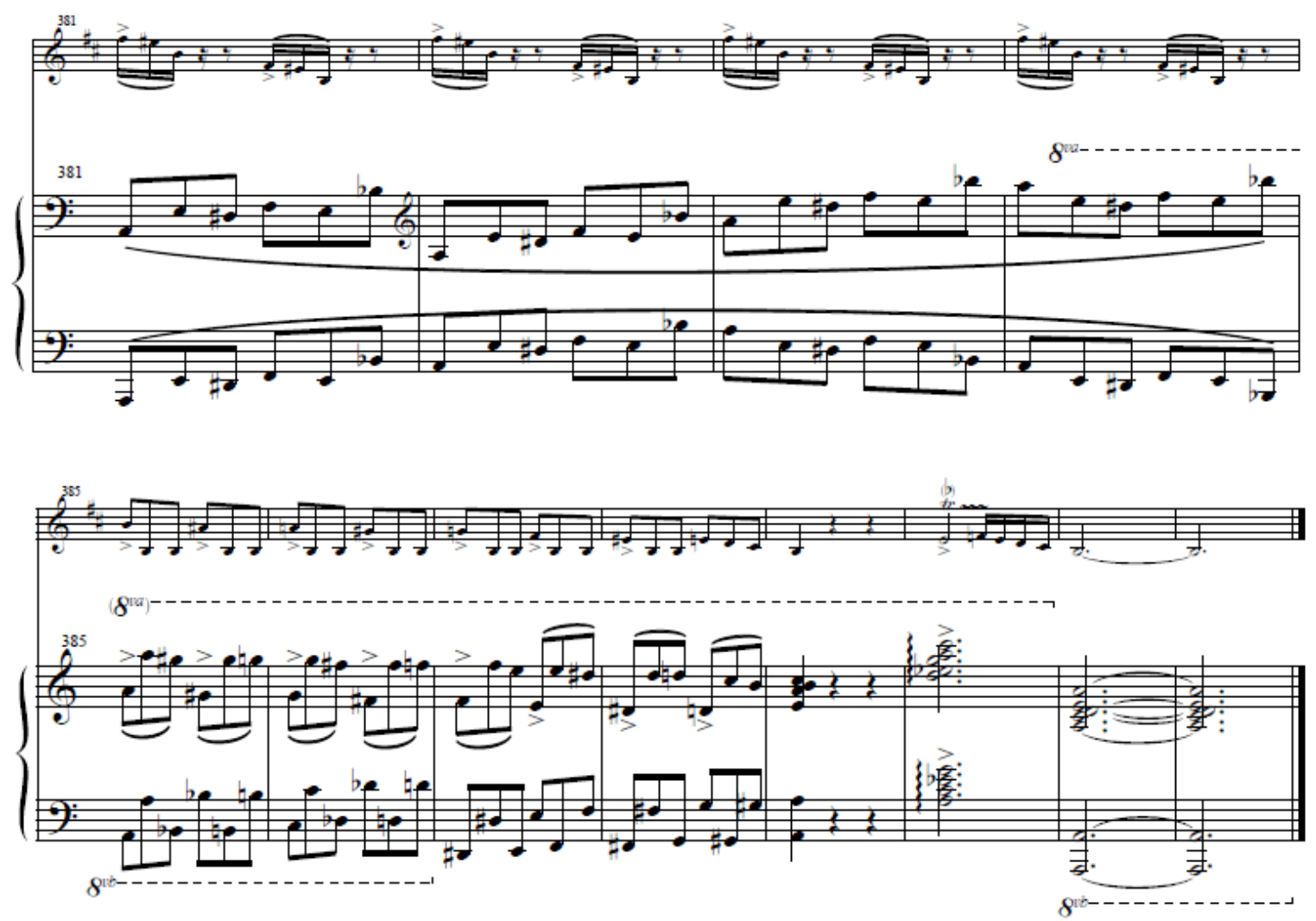

In sum, Salazar's treatment of the piano as a collaborative instrument in the Rapsodia para clarinete y piano evidences an extended use of virtuosic elements, percussive qualities, expressive sonorities, driving folk rhythms, exotic syncopations, and varied articulations. Bambuco, pasillo, danza, and other Latin American rhythms combined with jazz harmonies in the context of a traditional tonal writing are some of the main characteristic elements. This exciting work requires a high degree of technical command of the instrument. The piece also constitutes an extraordinary source of learning for a collaborative pianist. 


\section{Chapter 5}

\section{Mauricio Arias}

\section{Life}

Dr. Mauricio Arias is undoubtedly one of the most celebrated Colombian musicians of his generation. Despite his young age, he has developed an outstanding international career as a pianist, composer, and improviser. A charismatic artist, he has been heard in Colombia, Cuba, Panamá, Poland, United States, Germany, and Italy. Arias was born in Bogotá in 1984, and began his formal piano studies at age 13 with Polish pianist and pedagogue Ludmila Weber at the pre-college division of the Pontificia Universidad Javeriana in Bogotá.

From the beginning of his career, Arias showed not only an exceptional talent, but also a high degree of devotion towards his instrument. His discipline and hard work during his formative years were decisive for his early success as a pianist. Throughout the eight years he spent as a piano student of Mrs. Weber, he performed at important concert halls in Colombia and abroad, appeared as a soloist with several orchestras, and was prize-winner at many national and international piano competitions including first prizes at the First National Chopin Competition in Bogotá (2005), and the UIS National Piano Competition in Bucaramanga (2005) among others. He rapidly became one of the most promising Colombian young musicians. In 2005, Arias earned a Bachelor's Degree in piano performance summa cum laude from Fundación Universitaria Juan N. Corpas.

After completing his undergraduate studies, Arias traveled to the United States to pursue his Master of Music and Doctor of Musical Arts degrees at Arizona State 
University, where he studied with Drs. Baruch Meier and Robert Hamilton. During this time period, Arias continued participating in important piano competitions such as Kingsville Isabel Scionti Piano Competition in Texas where he was awarded first prize, and Schimdbauer and Peabody Mason Piano Competitions where he won second prizes. In 2012, Arias graduated with a Doctor of Musical Arts degree in performance at Arizona State University. In the United States, he also had the opportunity to attend the master classes of Joaquín Achúcarro, Eteri Andjaparidze, and Vladimir Feltsman. ${ }^{33}$

Although the main focus of his career was obviously the piano, Arias also started to show interest in music composition since he was a student in Bogotá. During his time at Fundación Universitaria Juan N. Corpas, he attended the composition class of Colombian composer Jorge Humberto Pinzón. ${ }^{34}$ Later, at Arizona State University, he studied composition with Dr. Rodney Rogers. In 2012, as his DMA final project, Arias composed and premiered his Rapsodia Camaleónica for Piano, Trumpet, and Orchestra, presenting it later the same year at Carnegie Hall in New York. After graduation, he continued to develop his formation as a composer by attending the Synthetis summer courses for composers in Poland. He also developed a particular interest in improvisation, incorporating it into his compositions and using it as a pedagogical tool.

After his return to Bogotá in 2014, Arias has worked as an educator and staff pianist at Fundación Universitaria Juan N. Corpas and Universidad Nacional de Colombia, and he has been recently appointed professor of piano at Universidad de los Andes. He continues composing and performing as soloist and as chamber music partner with world-renowned

\footnotetext{
33 “Mauricio Arias Composer/Pianist," Mauricio Arias, accessed April 02, 2017, http://mauricioariasmusic.com/.

${ }^{34}$ One of the composers studied in chapter 6 of this research paper.
} 
musicians in Colombia and abroad. He has collaborated with artists like: Valeriano Lanchas, Betty Garcés, Juan Fernando Avendaño, Manuel Druminski, among many others. He has also recently founded the Bogotá Piano Trio, with German violinist Anyango Yarbo-Davenport and Colombian cellist Iván León.

As a pianist he has amassed a large repertoire and in his recitals he often includes his own improvisations and works, as well as music by other active Colombian composers such as: Jorge Humberto Pinzón, Blas Emilio Atehortúa, Gustavo Parra, Moisés Bertrán, Germán Darío Pérez, Juan Domingo Córdoba, Juan Antonio Cuéllar, Alejandro del ValleLattanzio, and Ian Frederick, among others. In an interview in 2010, Dr. Robert Hamilton, one of his teachers at Arizona State University, rightly described Arias as being "Very sharp at finding opportunities, presenting himself, and building his career."35

His catalog of works includes a total of eleven pieces for different instruments or ensembles. His works have been performed in Colombia, United States, Poland, Austria and Australia. He has written commissioned works for the Orquesta Sinfónica de Colombia, the University of Florida Symphonic Band, the Bogotá public schools choral program called ¡Canta, Bogotá, Canta!, and the Yamaha Brass Academy.

\footnotetext{
35 "Passion for the Piano", YouTube video, 2:48, posted by “Asuresearch”, July 14, 2010. https://www.youtube.com/watch?v=swXvoXIHcKg
} 


\section{Compositional Style}

In the introduction to the text portion of his DMA research paper "Rapsodia

Camaleónica: A Concerto for Piano, Trumpet and Chamber Orchestra," Arias states that his work:

Incorporates many different compositional techniques, including phasing, motivic transformation, motivic compression and augmentation, modality, varied scale forms (pentatonic, octatonic, chromatic), sequence, LatinAmerican rhythms (especially bambuco), fugue and harmonic ostinato. Musical influences include Minimalism, Armenian music, Brazilian concert music, Colombian bambuco and Salsa, among others. ${ }^{36}$

An interesting mixture of all of these compositional procedures is the landmark of his music. As previously discussed in this research paper, Colombian folk traditions are so strong that it is almost impossible for a Colombian composer of art music to ignore the richness of that musical tradition. In the case of Arias's works, this Colombian "accent" is absolutely evident. Besides the influence of traditional Colombian folk music, he has also drawn inspiration from the music of composers such as: Béla Bartók (1881-1945) and György Ligeti (1923-2006), as well as from minimalist Estonian composer Erkki-Sven Tüïr (b. 1959). In regard to his style, in an interview for the TV program Panorama for CM\& Television in Colombia, Arias mentioned:

\footnotetext{
${ }^{36}$ Mauricio Arias-Esguerra. "Rapsodia Camaleónica: A Concerto for Piano, Trumpet and Chamber Orchestra." (D.M.A. paper, Arizona State University, 2012), 1.
} 
Besides traditional music, there is a special composer that I really like: The Estonian Tüür. He chooses four notes and stays there for ten minutes! Also, in my recitals I like to include improvisations, and some of my own works. ${ }^{37}$

Arias explores the full potential of the instruments for which he composes. He often makes use of extended techniques. He achieves coloristic effects by playing on the strings of the piano, by asking for a specific metallic type of sound from the piano, ${ }^{38}$ or by utilizing several types of trumpet mutes. Those are only a few examples of the extraordinary variety of elements that he displays in his music.

37 "Personaje Panorama CMI: Mauricio Arias (Pianista)", YouTube video, 2:23, posted by Panorama, September 15, 2014. https://www.youtube.com/watch?v=PyDk6NhwYPY

${ }^{38}$ A specific type of harsh sound derived from the works by Hungarian composer György Ligeti, who used it in his Piano Etude No. 8, entitled "Fém," (which means "metallic" in the Hungarian language). 


\section{List of Works}

- Dynamo for string quartet (2006)

- Rapsodia Camaleónica for piano, trumpet, and chamber orchestra (2012)

- Toccata Bachkovsky for solo piano (2013)

- Snippets for solo accordion (2014)

- A la memoria de 21 Ángeles for trumpet and piano (2014)

- Arizona Mirage for solo piano (2015)

- Episodios Angulares I for solo multi-percussion (2015)

- A través de mis ojos (Homenaje a José Barros) for full orchestra (2015)

- Variaiciones Fantásticas sobre La Guaneña for solo trumpet and concert band (2016)

- ¡Oigo voces! for young choir and piano (2016)

- Entrada (o Salida) Concertante for two trumpet and brass quartet (2016)

- Despierta for youth choir and piano (2017) 


\section{“A la Memoria de 21 Ángeles"}

An Overview of the Work and a Collaborative Pianist's Perspective

The work A la memoria de 21 Ángeles (In memory of 21 Angels) for trumpet and piano by Mauricio Arias, was composed in 2014 for the internationally renowned Colombian trumpet player Juan Fernando Avendaño, the current principal trumpet of the Orquesta Sinfónica de Colombia and Artistic Director of the Academia Colombiana de Trompeta. The piece is dedicated to the memory of the 21 children who lost their lives in a tragic school-bus accident in Bogotá on April 28, 2004. A typical performance of this piece lasts approximately eight minutes.

The work was premiered by Avendaño and Arias at the Concurso Iberoamericano de Trompeta Eric Aubier, in the city of Medellín, Antioquia, in 2014. They performed the piece at the emblematic Teatro de Cristóbal Colón in Bogotá in January 2015. The two artists also recorded and included it, along with six other Colombian pieces for trumpet and piano, in the album Juan Fernando Avendaño, released in June 2015 in Bogotá. The music score has not been commercially published yet. ${ }^{39}$

Arias's particular interest in the trumpet started by the time he was a student at Arizona State University, when he had the opportunity to collaborate with Mexican trumpet player and close friend Antonio Villanueva, a fellow student. In fact, Villanueva was the dedicatee of the composer's successful Rapsodia Camaleónica for piano, trumpet, and orchestra in 2012. After A la Memoria de 21 Ángeles, Arias composed one more piece for

\footnotetext{
${ }^{39}$ Juan Fernando Avendaño, Sergei Sichkov and Mauricio Arias. Juan Fernando Avendaño. Juan Fernando Avendaño, 2015, CD.
} 
this instrument: Variaciones Fantásticas sobre "La Guaneña" for solo trumpet and concert band (2016).

In contrast with other works by the same composer, A la Memoria de 21 Ángeles is a highly descriptive melancholic piece, charged with a deep emotional intensity. The work begins with 21 sounds of the piano, followed by the first melodic line in the trumpet. A second melody appears shaped as if it were a remembrance. Although the base of the piece is the metric irregularity originated at the beginning by grouping the first four measures as three measures in 5/8 plus one measure in $6 / 8$ (21 beats in total), it is absolutely fascinating to observe some veiled references to Colombian-Andean rhythms. These rhythmic allusions permeate the whole work.

The middle section of the piece, marked A bit faster (starting at m. 110), is derived from the melodic line of the trumpet; this time the note values are augmented. In this section, 21 long notes of the trumpet are accompanied by 21 different harmonies in the upper register of the piano. Later, the elaboration of the piano part leads to a recapitulation of the main melodic material. Then follows a piano interlude full of dissonances (mm. 241252) which ends with a fermata and prepares the emotional climax of the piece (m. 253): A highly descriptive cadenza in the trumpet which uses effects with the plunger mute and is accompanied by sounds produced by plucking the strings of the piano. The cadenza grows in intensity and the trumpet imitates the horn of the asphalt recycler approaching the school bus. At the moment of impact, the trumpet plays a repeated note in fff dynamic followed by a "vocal cry" of both performers at the same time with a percussive slam of the lid of the piano. After this shocking moment, the piece closes with the same 21 sounds that appeared at the beginning. 
Arias's writing for the piano is idiomatic and technically extremely difficult. In his description of the Rapsodia Camaleónica, he writes that the work was written "With a high degree of virtuosity for both the trumpet and piano parts. The piece is for advanced performers." ${ }^{40}$ This description could apply to virtually all of his instrumental compositions. His formidable career as a virtuoso pianist and improviser is reflected in his style. The composer explores all the technical possibilities of the instrument; although A la memoria de 21 Ángeles is not a virtuosic piece like his Toccata Bachkovsky (2013) and his Rapsodia Camaleónica (2012), it still contains considerable technical and musical challenges for the pianist.

Arias is very specific with his indications in the score, even offering some fingerings occasionally. The fact that he has recorded this piece himself is also a point of reference in terms of tempos, colors, articulations, etc. He accompanies his tempo markings with metronome indications.

The piano establishes the character of the piece at the beginning. A nostalgic sounding of the first 21 notes in the piano part, exploring all the registers of the instrument and with occasional crossing of the hands, different articulation, and metric irregularities, requires a careful approach from the pianist (see Example 5.1).

\footnotetext{
${ }^{40}$ Mauricio Arias-Esguerra. Rapsodia Camaleónica: A Concerto for Piano, Trumpet and Chamber Orchestra, 17.
} 
Example 5.1. Mauricio Arias, A la memoria de 21 Ángeles, mm. 1-6.

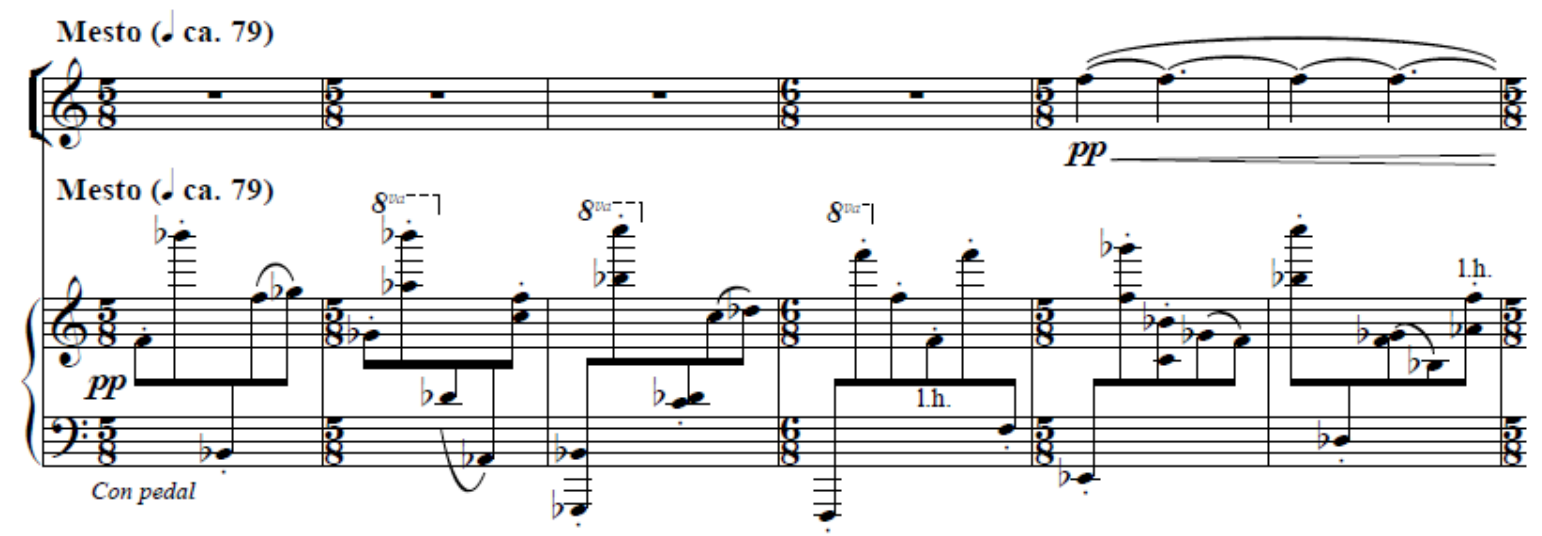

The eighth rest so characteristic of Colombian-Andean music is one of the characteristics of this piece. It brings unity and rhythmic variety to the melodic-harmonic material (see Example 5.2).

Example 5.2. Mauricio Arias, A la memoria de 21 Ángeles, mm. 13-18.

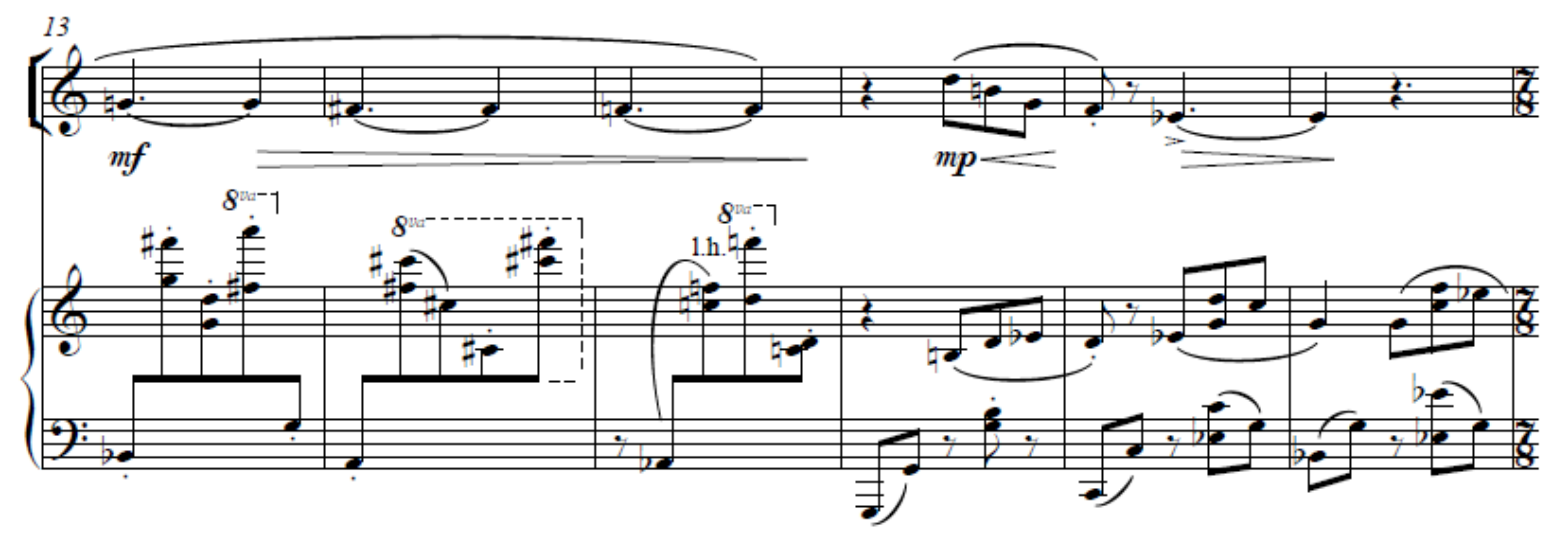

The rhythmic irregularity that permeates the work is exemplified by constant metric changes that have to be studied carefully (see Example 5.3). 
Example 5.3. Mauricio Arias, A la memoria de 21 Ángeles, mm. 19-24.

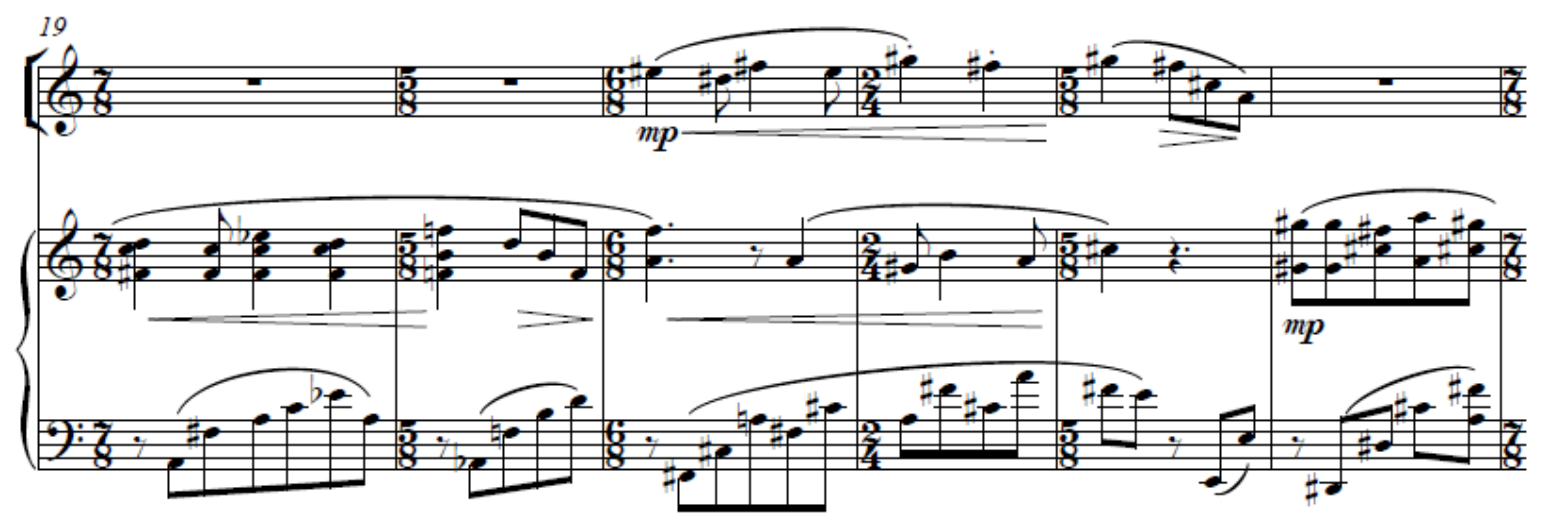

One of the characteristics of Arias's pianistic treatment is the profuse use of octaves to enrich the texture throughout the piece (see Example 5.4).

Example 5.4. Mauricio Arias, A la memoria de 21 Ángeles, mm. 54-58.

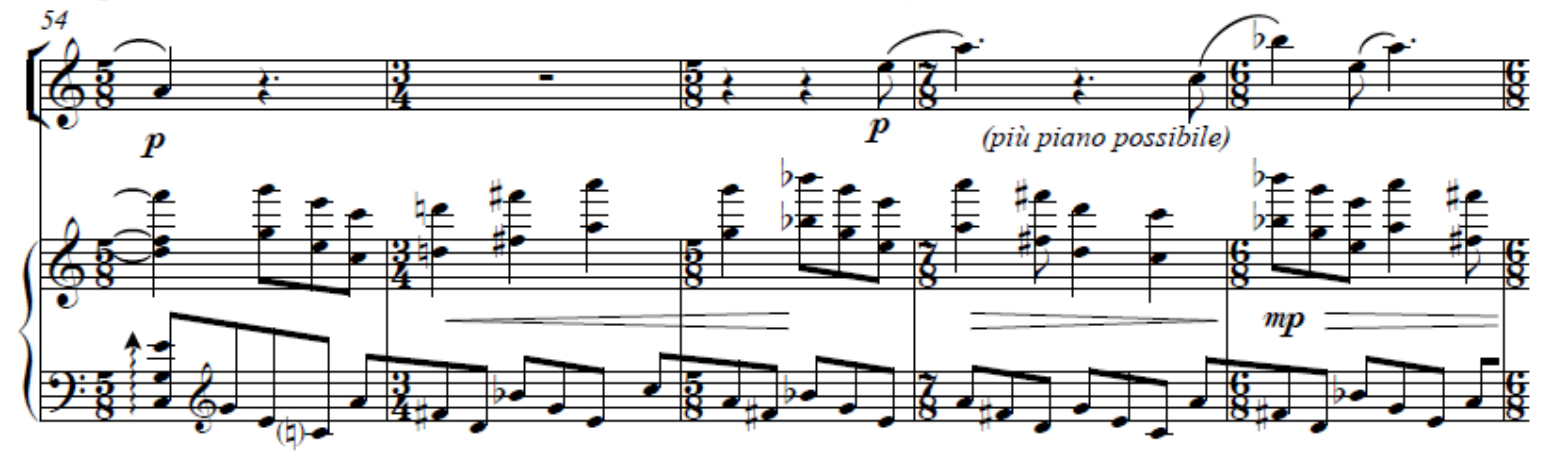

The pianist must be aware of the canonic writing. In measure 72 , for example, the trumpet, the right hand and the left hand of the piano part begin the same motive one measure apart. These subtleties enrich the sonorities and require particular attention. (see Example 5.5) 
Example 5.5. Mauricio Arias, A la memoria de 21 Ángeles, mm. 72-78.

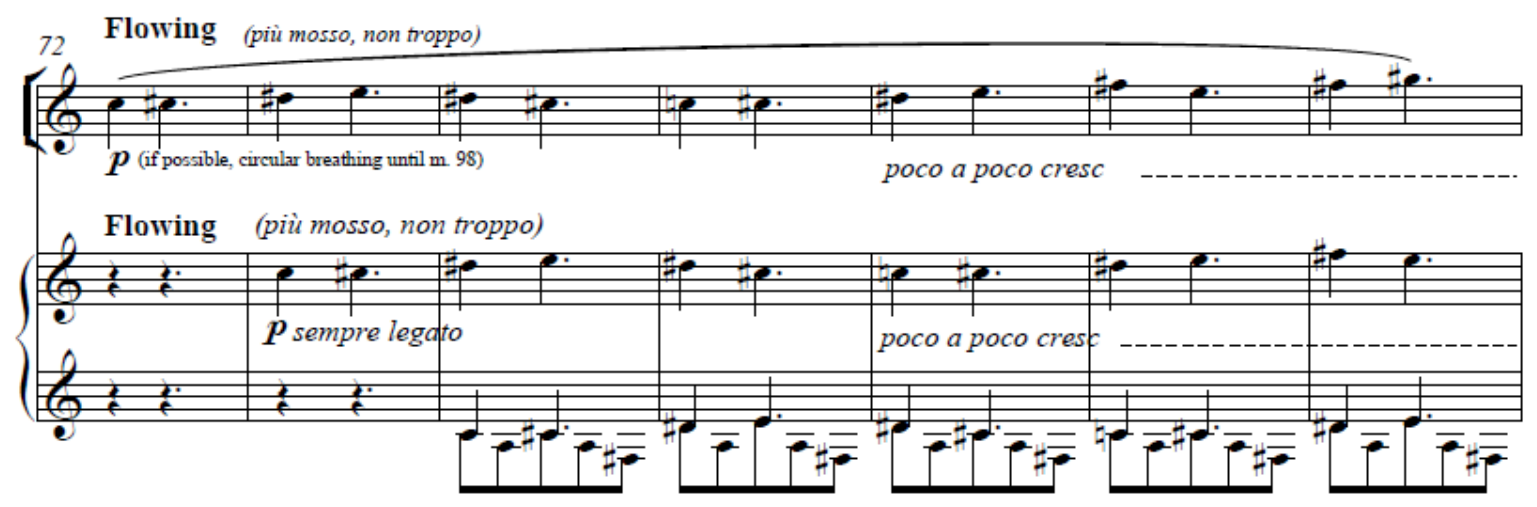

The piano texture contains many layers. The composer uses a three-staff layout in measures 104-109 to make this clear and also to clarify the subdivision of the compoundmetered measures (see Example 5.6).

Example 5.6. Mauricio Arias, A la memoria de 21 Ángeles, mm. 104-109.
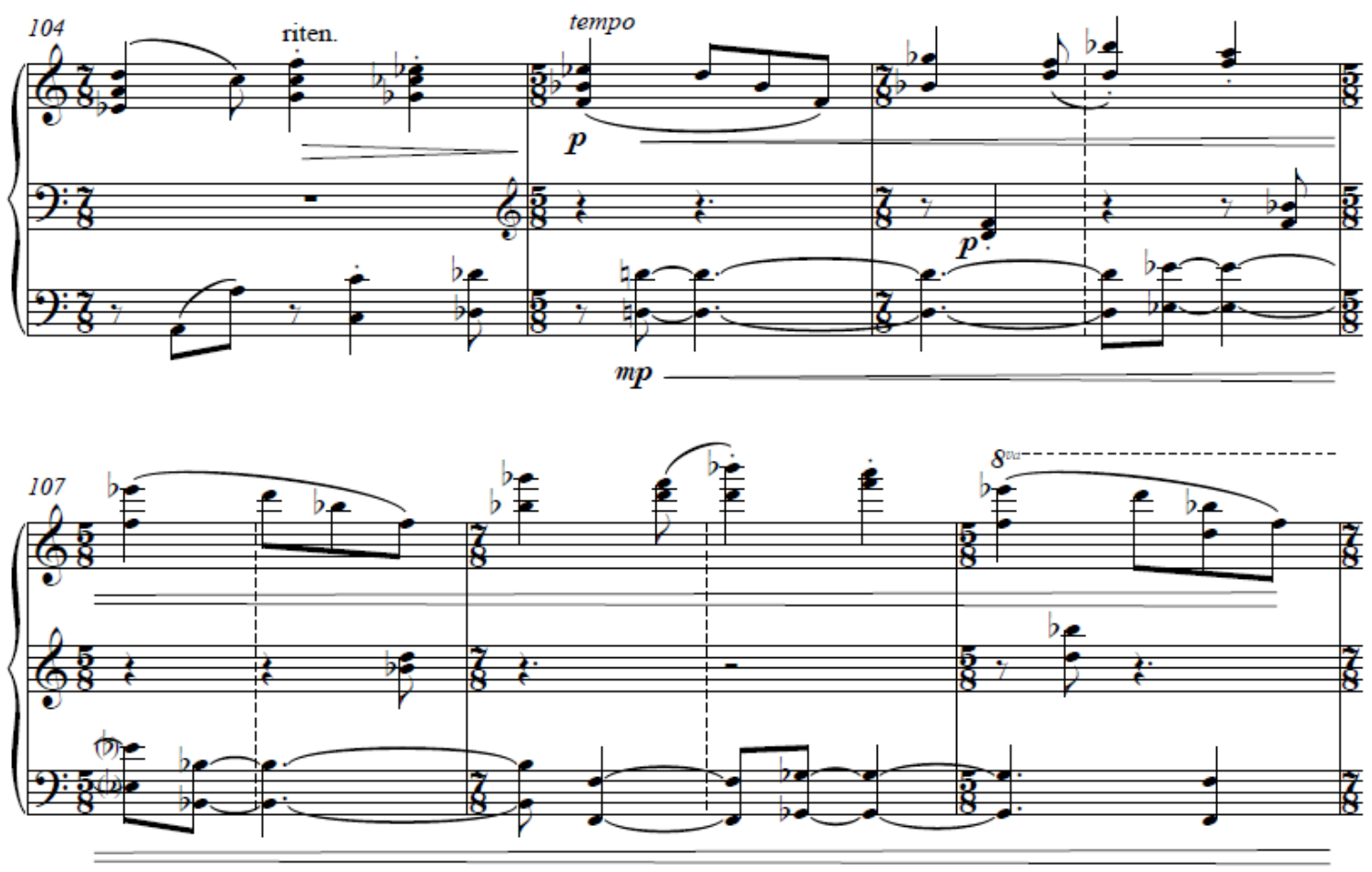

An important element of the composer's style is the use of phasing, making the two hands sound slightly out of synchrony by adding occasional extra notes in two similar patterns. Arnold Whittall defines phasing as: 
A term denoting the effect achieved when two instrumentalists or singers perform the same musical pattern at different (slightly increasing or decreasing) intervals of time, moving in or out of phase. ${ }^{41}$

This effect is characteristic of minimalistic music and it can be very difficult to achieve (see Example 5.7).

Example 5.7. Mauricio Arias, A la memoria de 21 Ángeles, mm. 110-114.

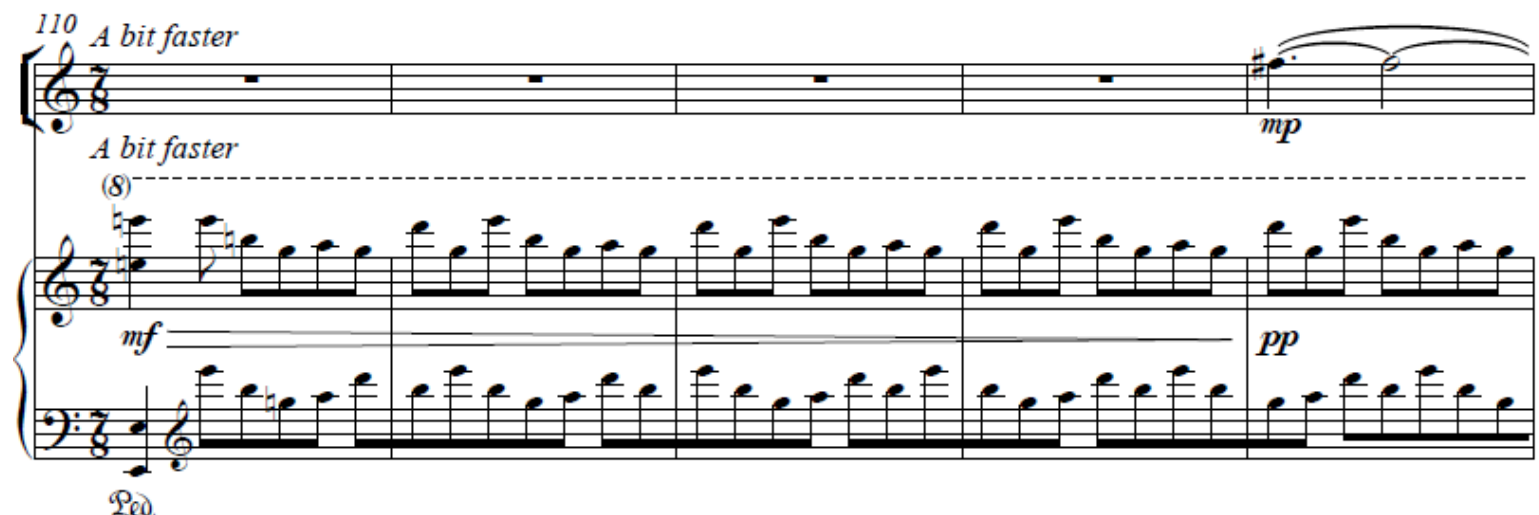

Also characteristic is the presentation of irregular melodies or countermelodies in the thumb of the left hand within a passage of rapid figurations (mm. 153-155, 172-176). (see Example 5.8)

Example 5.8. Mauricio Arias, A la memoria de 21 Ángeles, mm. 152-155.

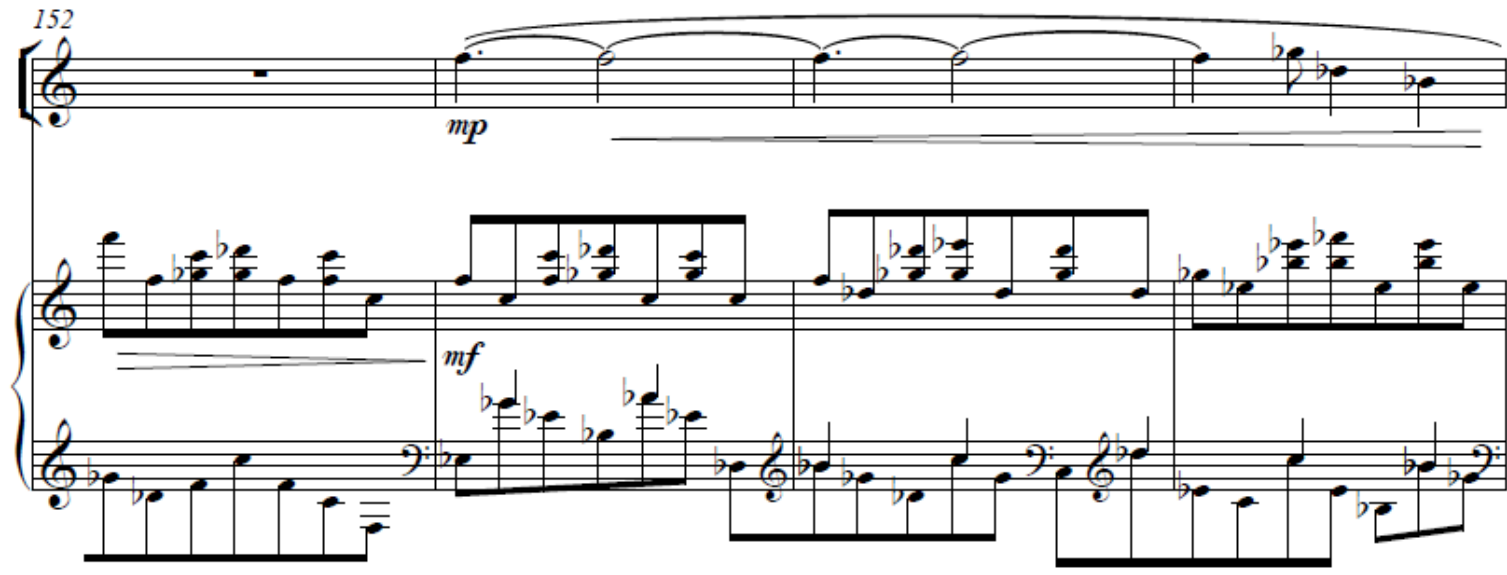

${ }^{41}$ Arnold Whittald. "phasing." The Oxford Companion to Music. Oxford Music Online. Oxford University Press, accessed April 2, 2017, http://www.oxfordmusiconline.com/subscriber/article/opr/t114/e5139. 
Piano interludes are extremely important in this piece. There are four of them in total (mm. 177-181, 198-208, 221-232, and 242-252). The treatment of the piano in the interludes is highly virtuosic. It emphasizes syncopations and metric irregularities. In these sections the piano displays thick textures, sophisticated passages of big chords and fast octaves, and melodic writing in both hands. (see Example 5.9)

Example 5.9. Mauricio Arias, A la memoria de 21 Ángeles, mm. 242-251.
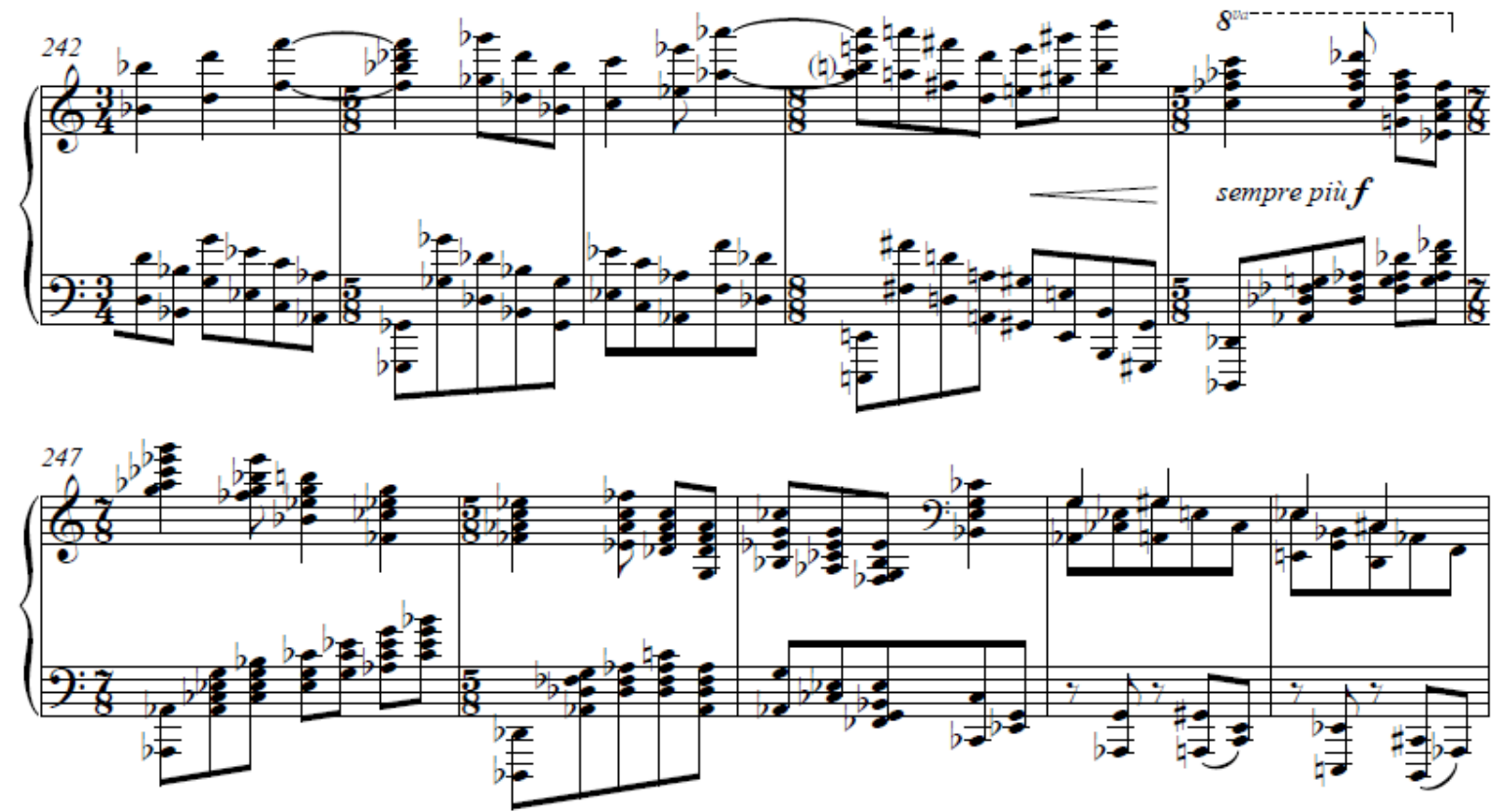

Obviously, the pianist needs to have a deep knowledge of the trumpet part. In fact, the piano often reinforces the melodic line by doubling it at different intervals, or in different registers (see Example. 5.10). 
Example 5.10. Mauricio Arias, A la memoria de 21 Ángeles, mm. 236-241.

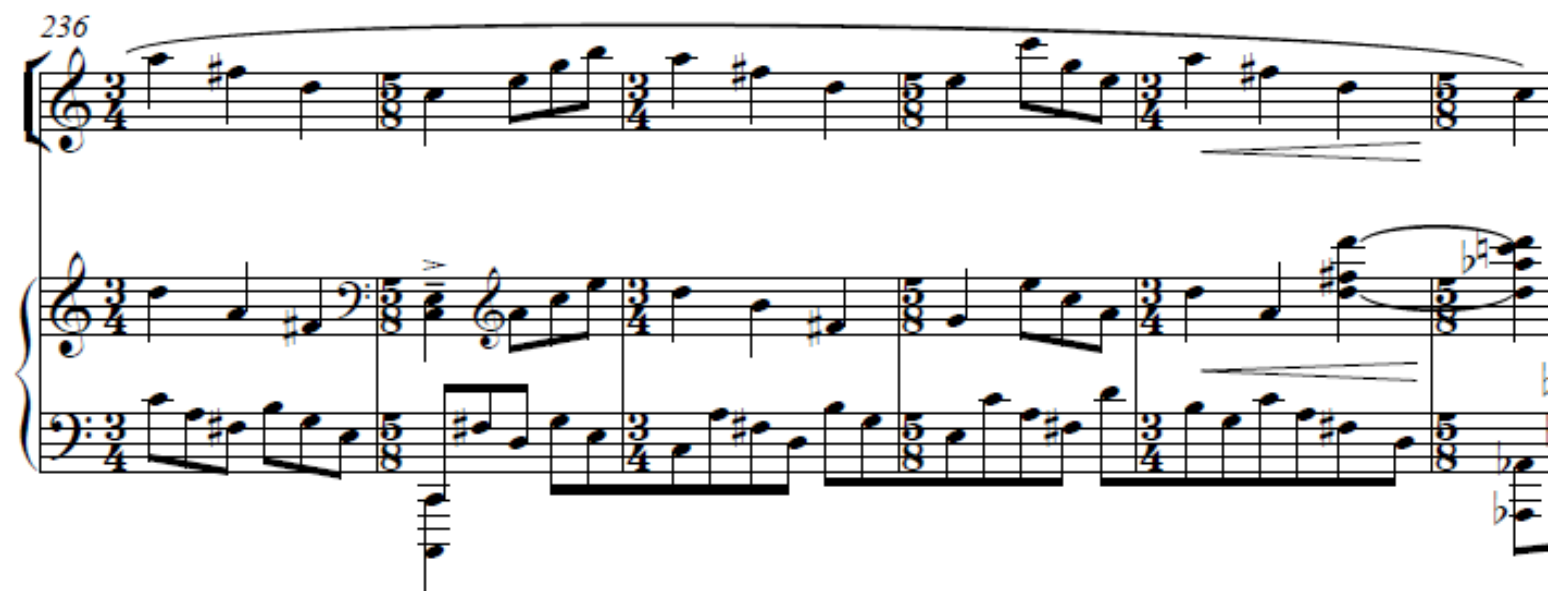

Finally, Arias asks for an interesting acoustic effect by silently pressing the keys, holding the damper pedal to create harmonics and plucking some of the strings inside the instrument. At the end of the cadenza, after a huge crescendo in the trumpet he also indicates a percussive slam of the keyboard lid marked fff and accompanied by a vocal cry: $A h$ ! which depicts the horrific moment of the accident. This is not only a creative way to use extended techniques but also a very effective one from an expressive point of view. It is important for the pianist to familiarize with producing these types of sounds because they do not appear frequently in the standard chamber music repertoire (see Example 5.11). 
Example 5.11. Mauricio Arias, A la memoria de 21 Ángeles, cadenza.
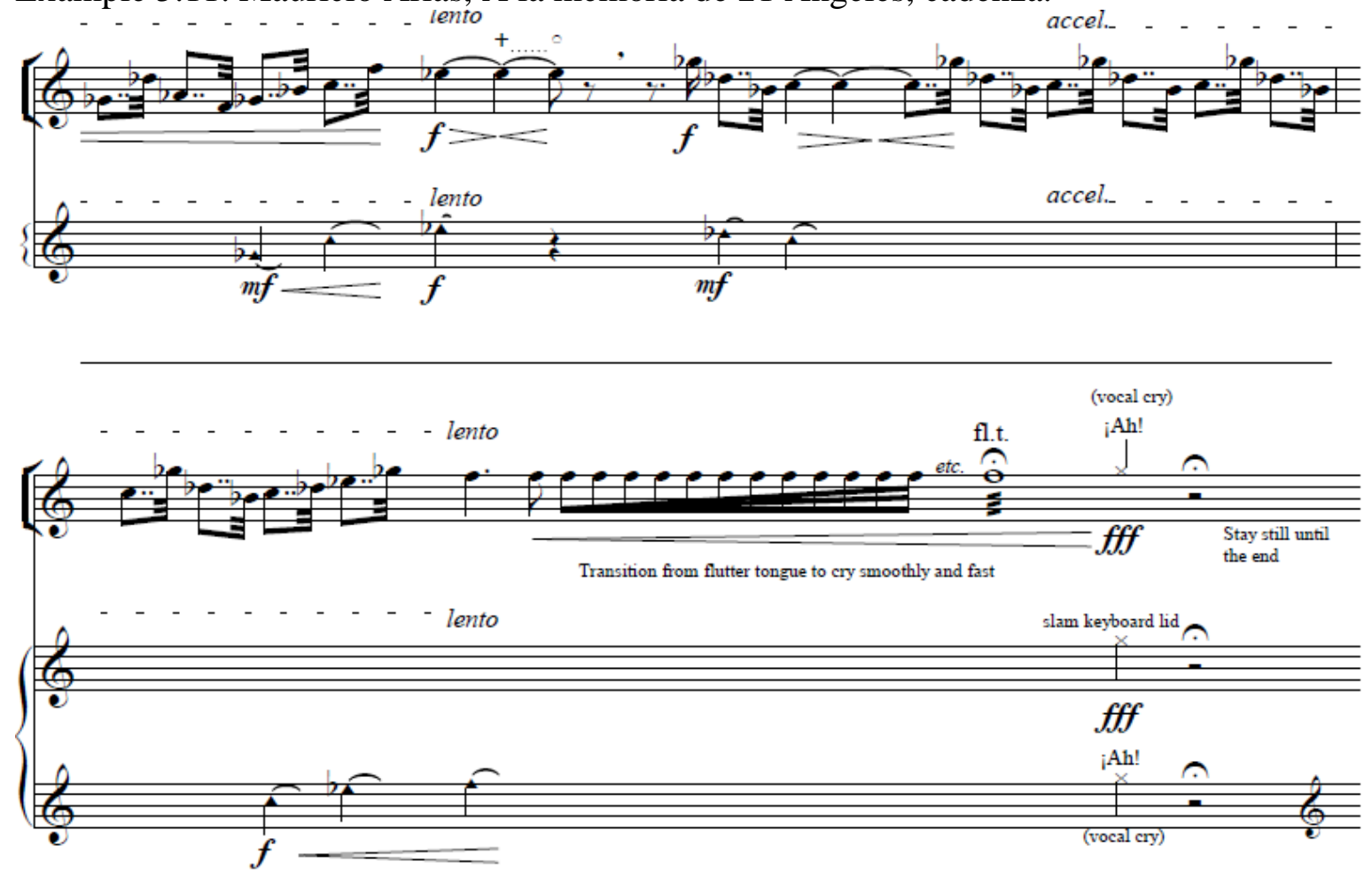

Arias is a pianist with an outstanding technique. In his compositions he often stretches the pianistic possibilities to the limit. The piano part in this formidable chamber music piece, although idiomatic, requires a high command of the instrument, and deep understanding of the composer's musical language. 


\section{Chapter 6}

\section{Jorge Humberto Pinzón}

\section{Life}

Jorge Humberto Pinzón is one of the most recognized Colombian composers in today's musical scene. He has developed an important career as a performer, composer and educator. His music has been heard in Colombia, Perú, Paraguay, México, Cuba, Venezuela, Russia, United States, Spain, Portugal, and Poland.

Pinzón was born in Moniquirá, Boyacá in 1968, into a family of musicians. He started his formal musical training in Tunja, Boyacá, in 1981, at the Escuela Superior de Música de Tunja, one of the most prestigious institutions of music education in Colombia at that time. He studied music theory and piano with Jorge Zorro Sánchez and oboe with Polish teacher Rizshard Jarosik. In 1984 he obtained second prize at the Primer Concurso Nacional de Piano Jóvenes Talentos in Bogotá.

In 1987, he moved to Cali to work as professor of solfège and harmony at the Conservatorio Antonio María Valencia, and as pianist of the classical ballet Incolballet. In 1988 he obtained a scholarship to travel to the Soviet Union to study at the prestigious Tchaikovsky Conservatory in Moscow where he studied oboe, piano and composition. His teachers there included Mamed Orudzhev, Boris Smolyakov and Vladislav Agafonnikov. He graduated with a Master of Fine Arts in 1992.

After he completed his studies in Moscow, Pinzón traveled to Perú, where was appointed principal oboe of the Orquesta Filarmónica de Lima, led by celebrated Peruvian conductor Miguel Harth-Bedoya. One year later, he returned to Colombia and became 
member of the Banda Sinfónica Nacional in Bogotá. After five years there, he resigned this position in 2000 and decided to dedicate all his efforts towards composition and teaching. ${ }^{42}$

In the following years he taught composition, orchestration, music theory, and aural training at Universidad Antonio Nariño, and was appointed chair of the music theory department at Fundación Universitaria Juan N. Corpas in 2003, a position that he still holds. He has also served as faculty member at Universidad Nacional de Colombia, Universidad Tecnológica de Pereira, and Universidad del Cauca.

His extensive catalog includes fifty works composed for a wide variety of ensembles. His music has received numerous national and international awards: Colombian pianist Mauricio Arias ${ }^{43}$ received a special award of best interpreter of music from his native country playing Pinzón's Evocación para Piano at the Concurso Iberoamericano de Piano in Havana, Cuba in 2001. In 2002, Pinzón also obtained first prize at the Tercer Concurso de Compositores Colombianos with his work Reflejo Sinfónico for full orchestra, which was performed by the Orquesta Sinfónica de Colombia. In 2005, Bulgarian trombonist Nestor Slavov premiered his Concierto para Trombón y Orquesta, with the Orquesta Filarmónica de Bogotá. In 2013, his chamber opera Muerte Accidental de un Anarquista was premiered in Bogotá.

Pinzón has established a reputation as one of the best teachers of composition in his country. Many of his students have had successful careers and have received scholarships and awards in Colombia and abroad.

\footnotetext{
${ }^{42}$ Paula Rodríguez-Moreno. "Vida y Obra del Maestro Jorge Humberto Pinzón Malagón” (B.M. monograph, Fundación Universitaria Juan N. Corpas, 2016). 29-42.

${ }^{43}$ One of the composers studied in this research paper.
} 


\section{Compositional Style}

Jorge Humberto Pinzón uses an enormous variety of compositional elements and styles in his works. Although there is a very subtle (almost imperceptible) influence of Colombian music especially in some syncopated rhythms and polyrhythmic motives present in his pieces, he is one of the very few Colombian composers that has preferred to resist the temptation of mixing folk traditions with academic language.

His music is influenced by Stravinsky, Prokofiev, and Shostakovich. Composers like Béla Bartók, Olivier Messiaen and Arvo Pärt could also be cited as influential in the development of his style. However, he has maintained a constant search for a distinctive style; despite his admiration for other composers, his works are characterized by an intriguing originality, a quality difficult to achieve for any composer in the present times. Spontaneity has also played a crucial role in the development of his compositional approach. A skilled improviser, Pinzón has used improvisation several times as the basis for some of his compositions. In an interview with researcher Paula Rodríguez, Pinzón said: "Improvisation has always been a crucial element for the development of my musical style". ${ }^{44}$

The magnificence of the universe as a creator of life and movement and its intimate connection with the musical systems through geographic representations, matter, time and space, have been a recurrent source of inspiration for him. The natural association of music and mathematics has played a significant role in the shaping of structures and forms as well. His music, regardless of its aesthetic principles, is in most cases the result of a convergence of tradition and innovation. Perhaps one of the main characteristics of

\footnotetext{
${ }^{44}$ Paula Rodríguez-Moreno. Vida y Obra del Maestro Jorge Humberto Pinzón Malagón, 43.
} 
Pinzón's music is the melodic treatment. The melody is an essential element of his compositions.

In a long interview with Colombian musicologist Maurico Peña at the Sala de Conciertos Luis Ángel Arango, Pinzón explained his style and his different compositional stages. The composer divides his career into two compositional periods or phases: The first period which includes his Evocaciones (Evocations) and his Constelaciones

(Constellations), is characterized by the confluence of the musical language of European composers at the beginning of the $20^{\text {th }}$ century with elements such as: harmonic-tonal expressive forms, altered harmonies, chromaticism, modalism, polytonalism, pantonalism, atonalism, dodecaphonism, serialism, pointillism, new simplicity ${ }^{45}$ minimalism, tintinnabuli, ${ }^{46}$ and micropolyphony, among others. ${ }^{47}$

The second period, which started around 2014 and is still developing, is more related to the phonetic-vocal qualities of the language and by the use of "controlled intuition.” These elements are carefully surrounded by sonorities (especially from the string instruments) that create an ethereal atmosphere, as if the noise and sound were generated mysteriously from the silence and the darkness. The works Pleyades for choir, string orchestra, and organ (2008) and Scorpius for soprano, violin, and piano (2010) are representative of this style. The most recent element that has been incorporated in his second compositional phase is which he has called "multicellular" music, in which the

\footnotetext{
${ }^{45}$ The intentional absence of inherent musical substance in compositions. In the New Simplicity, the development of ideas in the manner of Western classical music is carefully avoided, the stated goal being the attainment of a simplicity and "purity" of musical material and character. Josiah Fisk. "The New Simplicity: The Music of Górecki, Tavener and Pärt." The Hudson Review 47, no. 3 (1994): 402.

${ }^{46}$ A complex tonal technique created by Estonian composer Arvo Pärt.

47 "Entrevista Abierta a Jorge Pinzón, Compositor Colombiano", YouTube video, 1:34:37, posted by Banrep. November 9, 2016. https://www.youtube.com/watch?v=1KoHfrLIKN0
} 
manipulation of small motives originates larger structures. This new technique has been used in his clarinet quartet Polaris (2016). ${ }^{48}$

The composer believes in the constant evolution of his music. Therefore, he often makes revisions and adaptations of his own compositions. In a certain way, his works are always in progress. This is the main reason that explains why he has preferred not to make complete commercial recordings of his extensive catalogue. Besides sporadic recording projects, Pinzón has focused his efforts towards the development of his own creative processes.

${ }^{48}$ Paula Rodríguez-Moreno. Vida y Obra del Maestro Jorge Humberto Pinzón Malagón, 53-58. 


\section{List of Works}

- Moniquirá (pasillo) for piano (1990)

- Ilusión Fugaz I, II, III for piano (1990)

- $\quad$ Suite for two oboes (1991)

- Invención a dos voces for piano (1992)

- Invención a dos voces for piano (1993)

- Fuga for piano (1992)

- Sonatina for violin and piano (1992)

- Evocación for oboe and piano (1992)

- Fantasía for strings and synthesizer organ (1994)

- Tres miniature for solo clarinet (1996)

- Evocación for flute and piano (1996)

- Evocación for cello and piano (1996)

- Evocación I for marimba (1996)

- Evocación for trumpet and piano (1997)

- Concierto for oboe and strings (1998)

- Evocación for piano (1998)

- Preludio y Fuga for clarinet and piano (1998)

- Evocación II for marimba (1999)

- Fábula de los gnomos for symphonic band (2000)

- Fábula de los gnomos (orchestral version) (2001) 
- Reflejo Sinfónico for full orchestra (2001)

- Microcosmos for clarinet and string quartet (2001)

- Microcosmos for piano (2001)

- Toccata for piano (2002)

- Quintet for marimba, double bass, piano, and double percussion (2003)

- Procesión de Cobres for brass ensemble (2003)

- Orión for string quartet (2004)

- Toccata para la musa for piano (2004)

- Concierto for trombone and orchestra (2005)

- Casiopeia, suite for piano (2006)

- Andrómeda, rhapsody for violin and piano (2007)

- Reflejo Sinfónico (Version for symphonic band) (2008)

- Perseus for cello and piano (2008)

- Pleyades for choir, string orchestra, and organ (2008)

- Taurus for string quartet (2009)

- Taurus, symphony for string orchestra (2009)

- Scorpius, trio for soprano, violin, and piano (2010)

- Capricornius, concerto for violin and orchestra (2011)

- Danzas 1 y 2 for solo violin (2011)

- Mobile for double bass and piano (2012)

- Mobile for clarinet and piano (2012)

- Mobile for saxophone and piano (2012)

- El mensaje del colibrí for harp and strings (2013) 
- Muerte Accidental de un Anarquista, chamber opera (2013)

- Hydrus for cello and piano (2014)

- Sinfonía "La Pachamama” for full orchestra (2015)

- Cygnus for string quartet (2015)

- Evocación for tuba and piano (2016)

- Polaris for clarinet quartet (2016) 


\section{"Andrómeda"}

An Overview of the Work and a Collaborative Pianist's Perspective

The work Andrómeda, subtitled Rapsodia para Violín y Piano (Rhapsody for violin and piano), by Jorge Humberto Pinzón, was composed in 2007. The violin part was revised by renowned Colombian violinist and pedagogue Federico Hoyos. The piece was premiered the same year by violinist Pilar Zorro and pianist Leonardo Cáceres at Sala Otto de Greiff concert hall in Bogotá, and was performed at the Sala de Conciertos Luis Ángel Arango in 2010 by violinist Pablo Hurtado and pianist Karol Bermúdez. This short piece, which lasts about five minutes, has not been commercially recorded or published yet.

Andrómeda, along with other similar works, such as Orión for string quartet (2004), and Casiopeia for solo piano (2006), belongs to the cycle of the Constelaciones. The names of the pieces in this cycle are not related to Greek mythology; on the contrary, they symbolize the grandness of the universe as the creator of life, movement, shapes, colors, and magnificent structures. The immensity of the universe and its enigmatic relationship with the musical systems, geometric shapes, matter, time and space constitute the main source of inspiration for this work. Often associated with the universe, the planets, nature, human emotions, the human body, supernatural forces, arithmetic, logic and rhetoric, music

for Pinzón represents an unrivaled form of expression. ${ }^{49}$

The architecture of the piece is delineated as a three-sectional structure: Scherzoso Nebuloso - Scherzoso with a short enigmatic introduction marked Andante Enigmatico (mm. 1-20). The harmonic and melodic languages of the work are characterized by a Neo-

\footnotetext{
${ }^{49}$ Paula Rodríguez-Moreno. Vida y Obra del Maestro Jorge Humberto Pinzón Malagón, 48.
} 
Classical style. In concordance with the overall character of this work, the composer prefers not to use Colombian rhythms, in his search for a universal "cosmic" sound effect instead of a national one.

The use of the piano in Andrómeda is not ambitious from a technical point of view. However, it represents challenges in terms of balance, voicing, and qualities of the sound. The composer's indications for tempo are very specific, including metronome markings. Pedaling is also indicated in detail.

The first element to notice is the indication Andante Enigmatico (quarter note $=86$ ). This reveals the composer's preference for a flowing tempo. This is crucial because in the third measure, after the opening, the piano part presents a fast figuration of $32^{\text {nd }}$ notes alternating between the hands. Rhythmic accuracy in this opening is extremely important. This figuration will be repeated in measures 9-11 and 15-18. (see Example 6.1) 
Example 6.1. Jorge Humberto Pinzón, Andrómeda, mm. 1-6
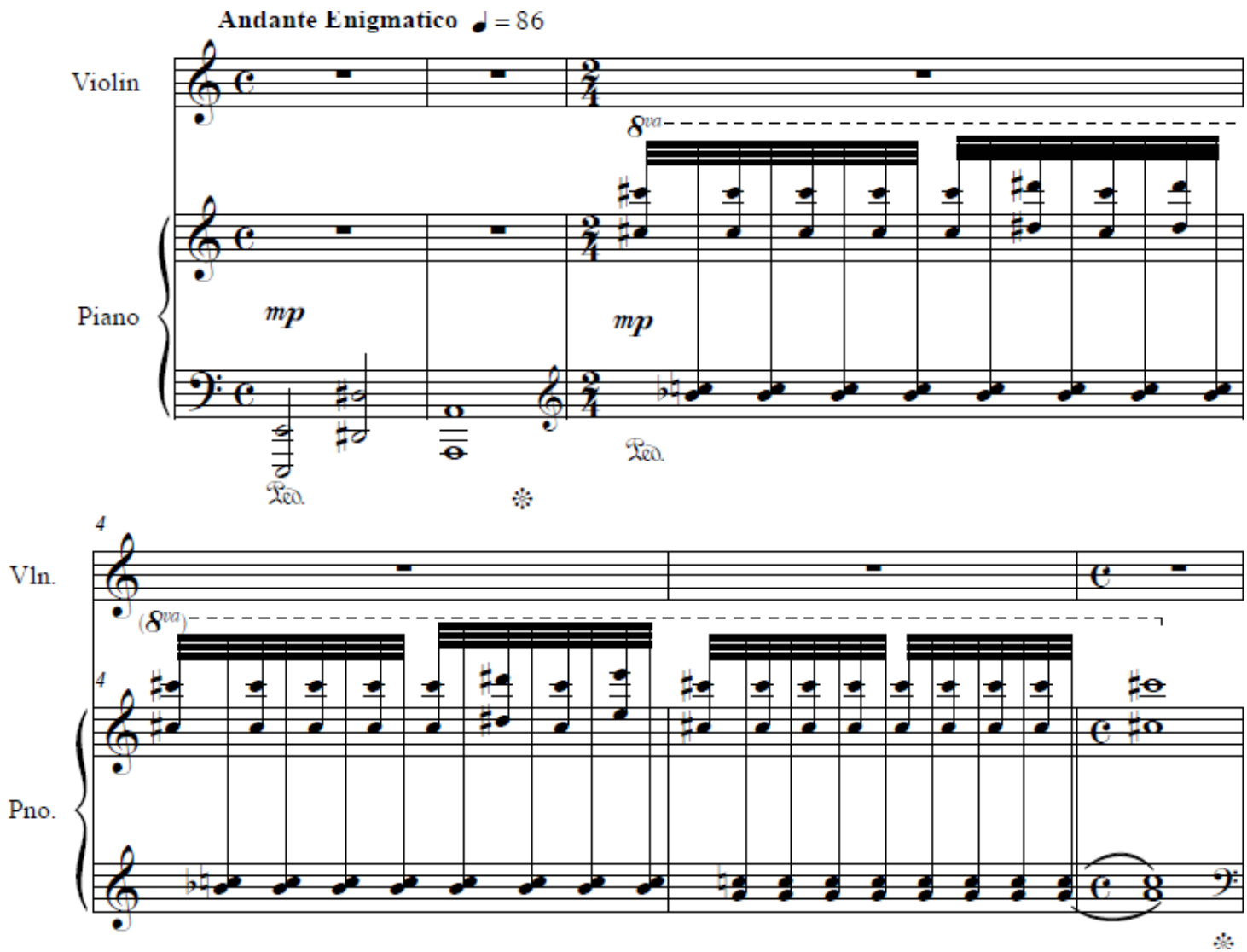

In the scherzoso sections, the piano is the harmonic support. The use of the low register of the piano in these passages of repeated block chords, the sudden dynamic changes, the accents on the second beat, and the register of the violin, require particular attention from the pianist. Good voicing is needed in order not to overpower the violin (see Example 6.2). 
Example 6.2. Jorge Humberto Pinzón, Andrómeda, mm. 21-26.

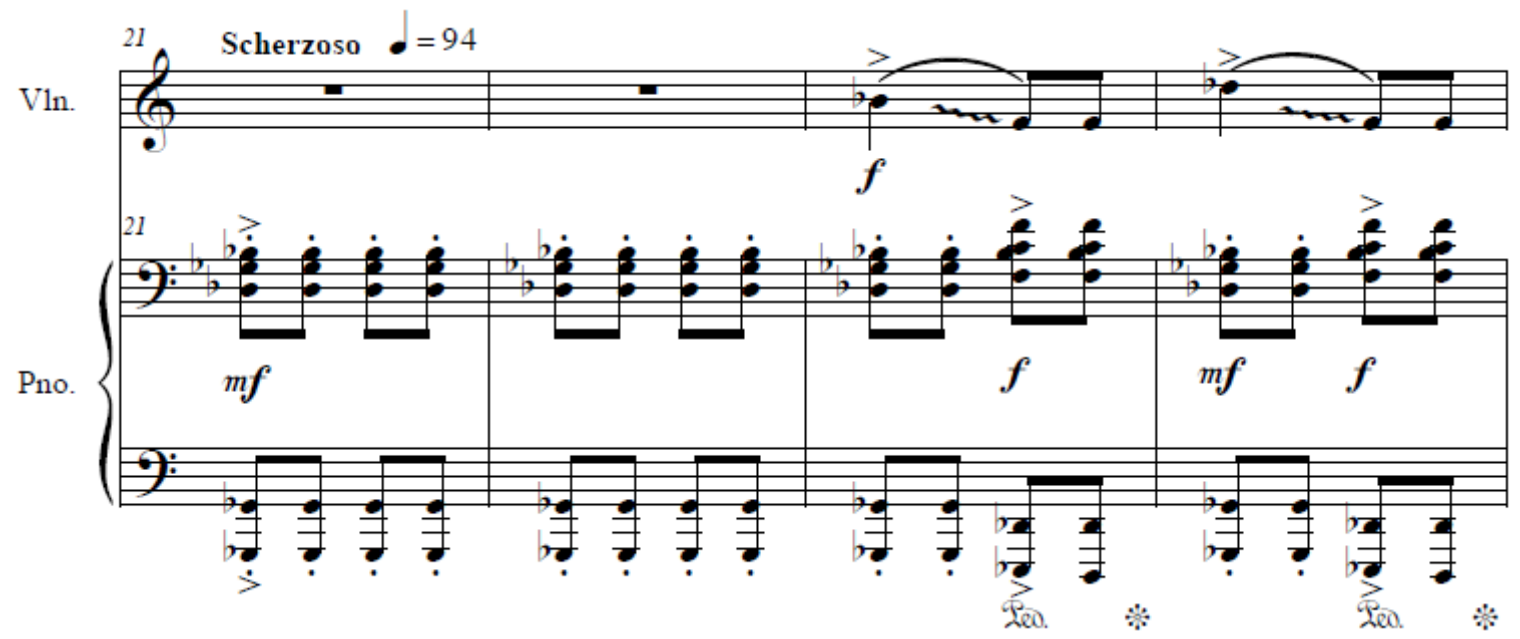

Passages of legato double notes in the right hand (mm. 42-49) are particularly difficult, not only because of the necessity to use the fourth finger, but also because the dynamic marking is $m p$ (see Example 6.3). 
Example 6.3. Jorge Humberto Pinzón, Andrómeda, mm. 44-51.
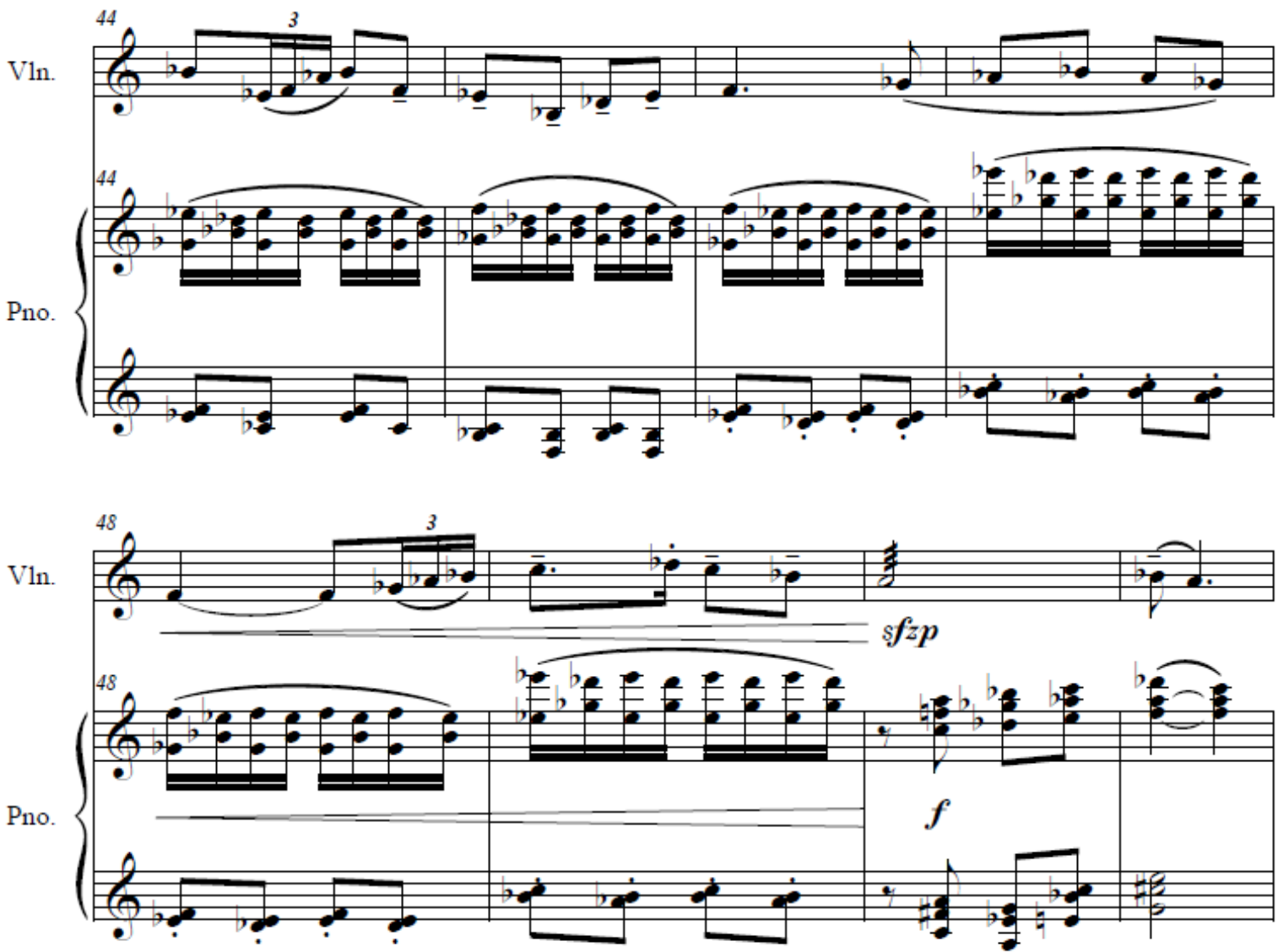

Left-hand arpeggio octaves in the low register and different articulations are also challenging. (see Example 6.4)

Example 6.4. Jorge Humberto Pinzón, Andrómeda, mm. 57-58.

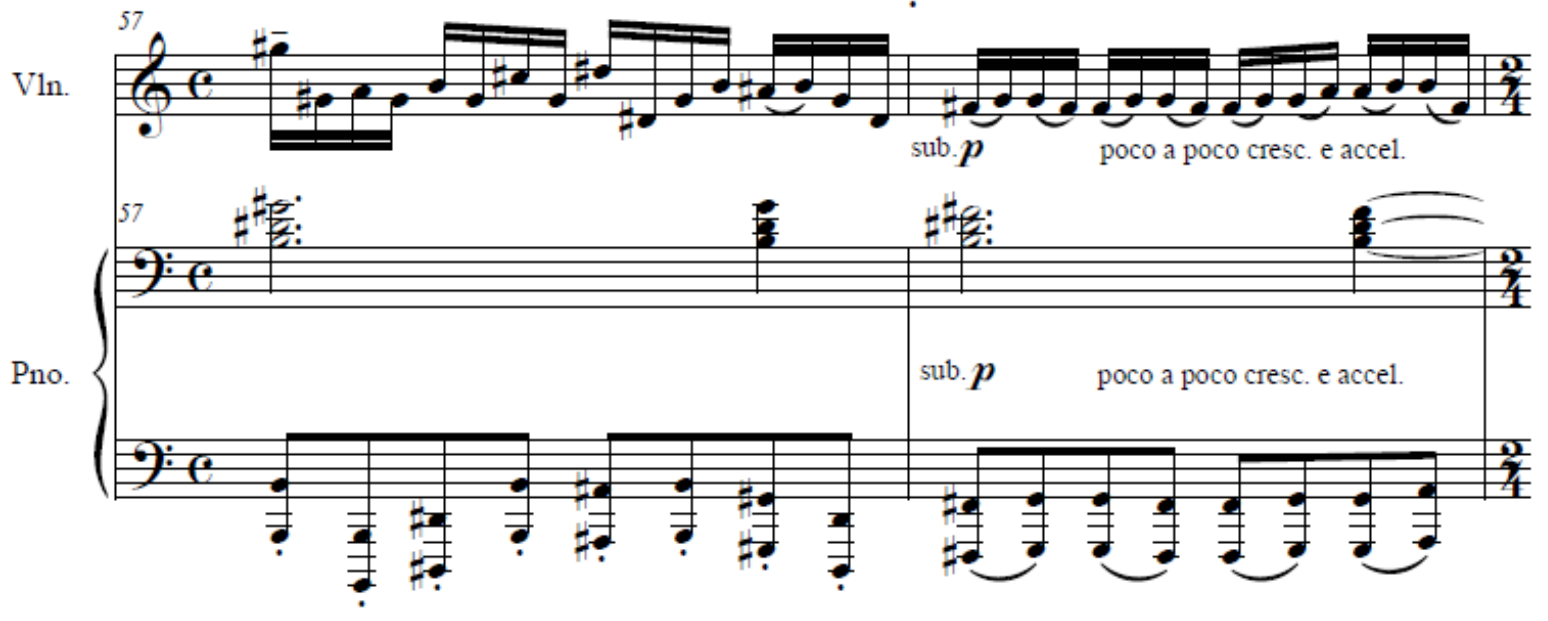


An expressive quality in the voicing of the chords is also necessary in the middle section, where the piano creates a subtle atmosphere over which the violin presents the beautiful melodic material. (Example 6.5)

Example 6.5. Jorge Humberto Pinzón, Andrómeda, mm. 73-83.
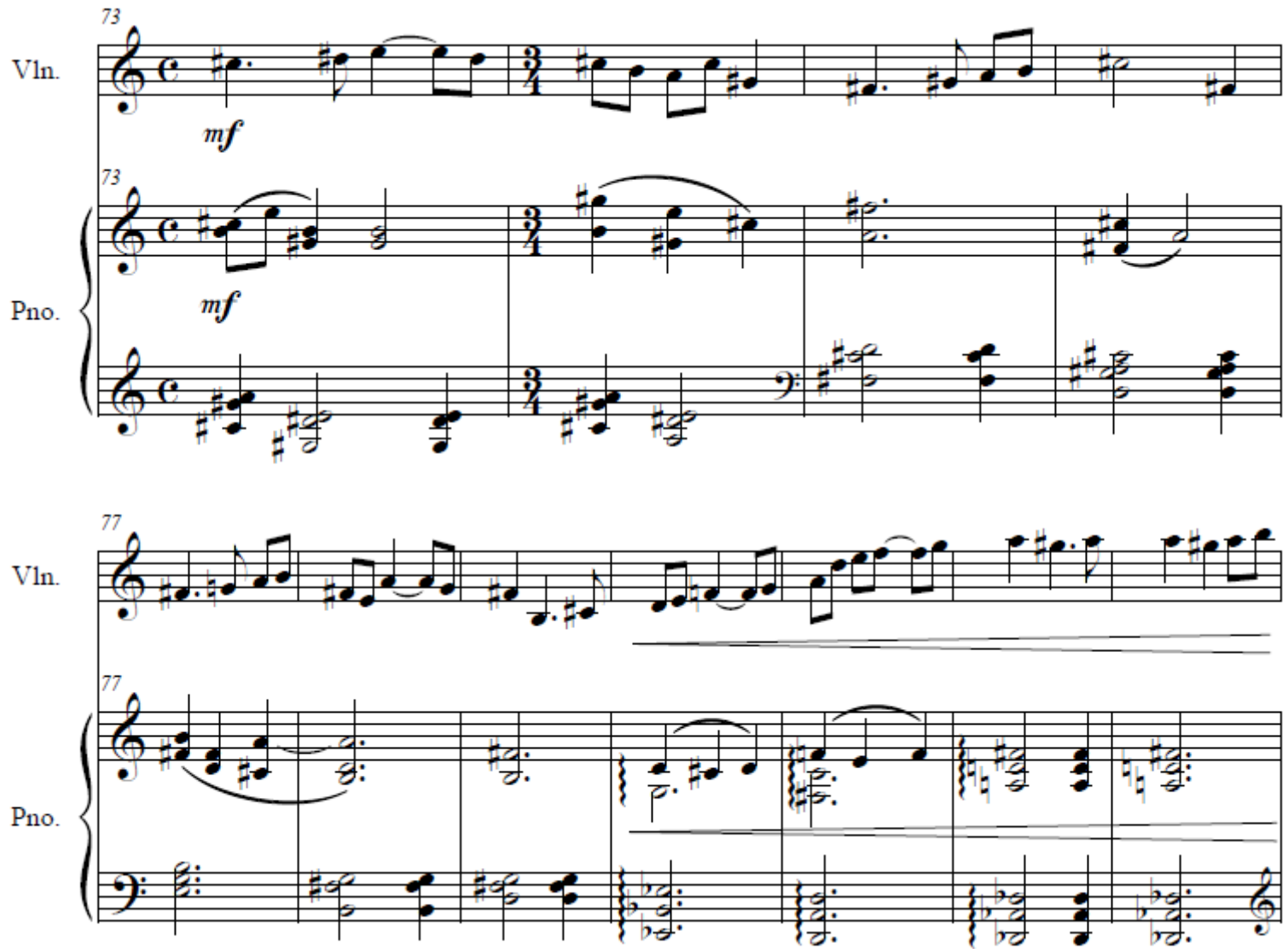

The role of the piano in Andrómeda is of vital importance. In fact, the piano is the instrument that opens all the different sections of the piece (introduction, scherzoso, nebuloso, scherzoso). The pianist, as an equal partner to the violinist, has the responsibility of establishing the correct tempos and the right moods in the piece. 


\section{"Scorpius"}

Overview of the Work and a Collaborative Pianist's Perspective

The trio Scorpius subtitled Presencia de una Voz Ancestral (Presence of an Ancestral Voice) for soprano, violin, and piano, also belongs to Pinzón's cycle of the Constelaciones (Constellations). It was composed in 2010. The work has not been performed in public yet. It has not been commercially published or recorded; however, the existence of a home-made recording, by violinist Federico Hoyos, soprano Catalina Rodríguez, and Pinzón himself at the piano, reveals much of the composer's intentions. ${ }^{50} \mathrm{~A}$ typical performance of the piece lasts approximately nine minutes.

The text is related to an exclusively intuitive perception of the phonetic-vocal possibilities of the human voice. The intriguing phonetic treatment of the text portrays a similarity with an enigmatic imaginary ancient language. The text is not written in a specific existing dialect. In fact, the words are made up: They do not have a real meaning. However, the configuration and the interaction of these words could be associated with unknown archaic languages. This particular approach to the organization of the phonemes is derived from the Gliglico, ${ }^{51}$ a language invented by Argentinian novelist, writer, and essayist Julio Cortázar (1914-1984) and present in chapter 68 of his celebrated work Rayuela (Hopscotch) (1963). ${ }^{52}$

\footnotetext{
50 “Jorge Pinzón - Scorpius, Trio para Soprano, Violín y Piano”, YouTube video, 9:36, posted by Jorge Pinzón. December 30, 2014. https://www.youtube.com/watch?v=hGgnWSAyZlw

${ }^{51}$ Glíglico has the same morphology and syntax of Spanish. It combines both real and invented words like substantives or verbs, and presents correct punctuation of the phrases.

${ }^{52}$ Julio Cortázar. Rayuela. (Madrid: Ediciones Alfaguara, 1984)
} 
The text is also related with resounding sentences that reveal diverse moods, different levels of consciousness and unconsciousness, and audible experiences from the past or the future. "It is the presence of an ancestral voice whispering in our ears" is how the composer summarizes his treatment of the text: ${ }^{53}$

\section{Senibiet, Crixinion, Opraviet Scorpius. \\ Remini Fixiste Loburatem. \\ Predixti Denonsi Faste. \\ Ibi, saneviteri. \\ Nepructus, Nepructus \\ Deni Sadenis. \\ Ibi, saneviteri. \\ Nepructus, Nepructus \\ Deni Sadenis. \\ Univeroni, Univeroni. \\ Senibiet Opraviet Scorpius.}

In Scorpius, an ethereal atmosphere of sonorities surrounds the enigmatic "meaning" of the text. These sounds not only emerge out of silence but also lead back to it. The harmonic material is developed around the musical concept of "New Simplicity." The character of the piece (calm and meditative) is reached through the use of modulations in Aeolian mode.

The treatment of the piano in Scorpius and Andrómeda is quite similar. The piano part is unambitious from a technical point of view. However, it is in charge of setting the character of the piece. Again, the Andante has a metronome marking that reveals the preference of the composer for a moving tempo.

\footnotetext{
${ }^{53}$ Paula Rodríguez-Moreno. Vida y Obra del Maestro Jorge Humberto Pinzón Malagón, 53.
} 
The pianist requires an absolute control over the sound. The color is very important in this piece, but also the legato articulation. A singing legato in octaves could be difficult to achieve (see Example 6.6).

Example 6.6. Jorge Humberto Pinzón. Scorpius, mm. 5-12

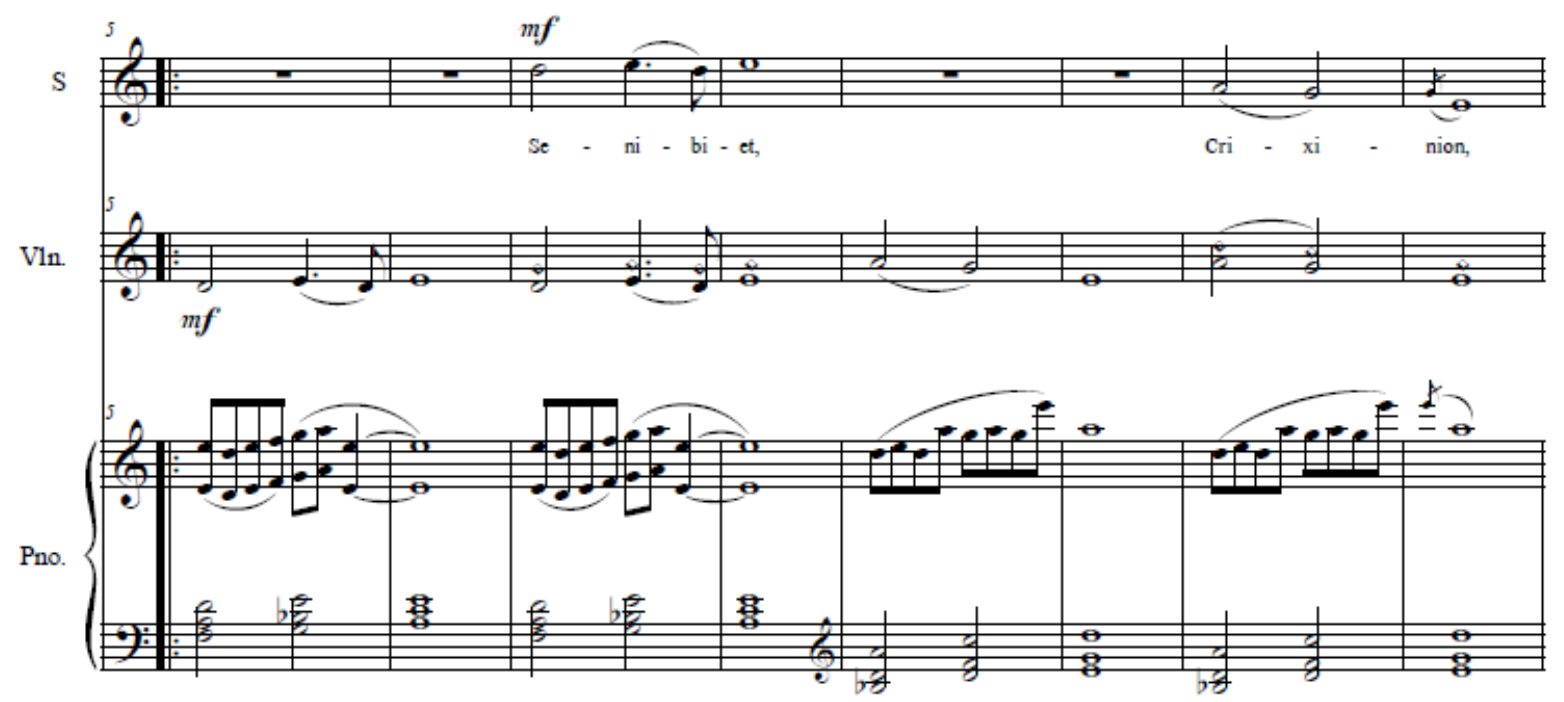

The piano often doubles the violin part in the same register and with exactly the same articulation (mm. 15-22). In fact, the slur of two notes, where the second one should be played with less volume than the preceding one, is one of the characteristic subtleties of this piece (see Example 6.7).

Example 6.7. Jorge Humberto Pinzón. Scorpius, mm. 13-22

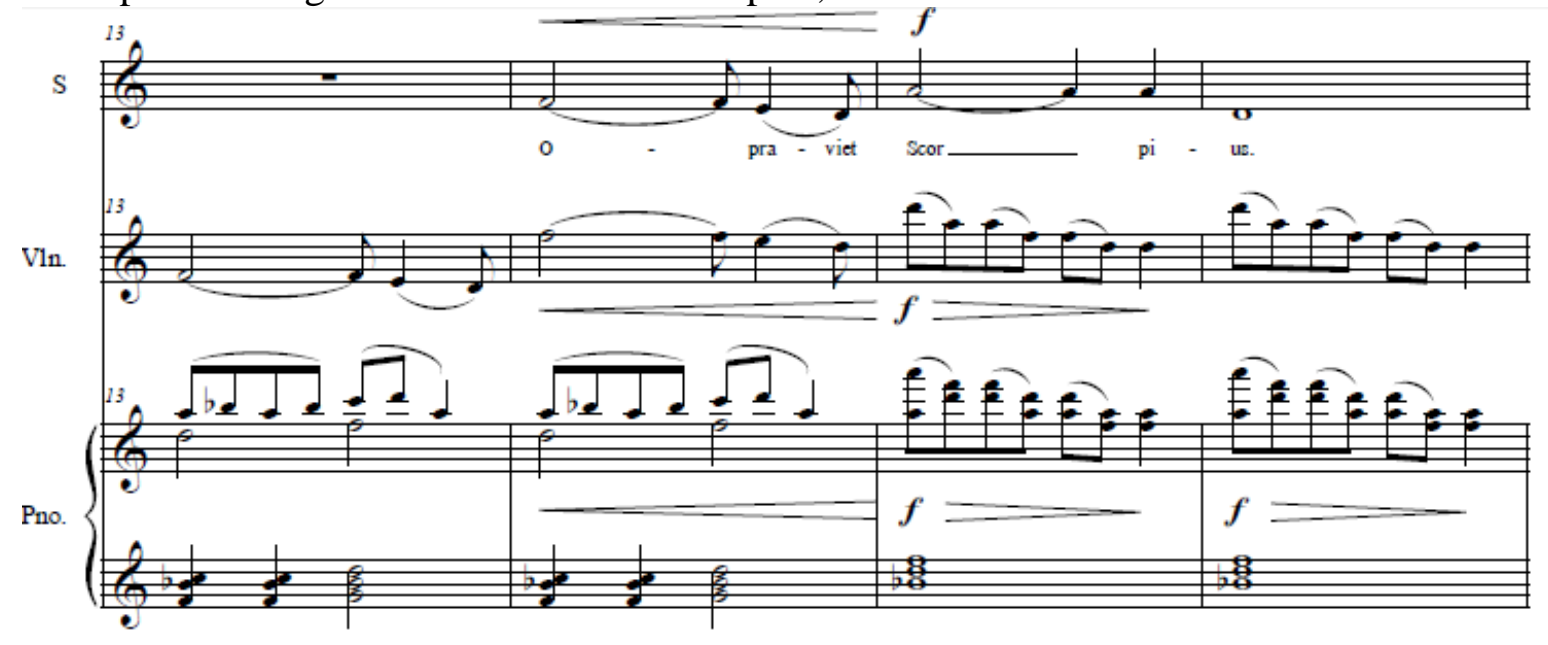




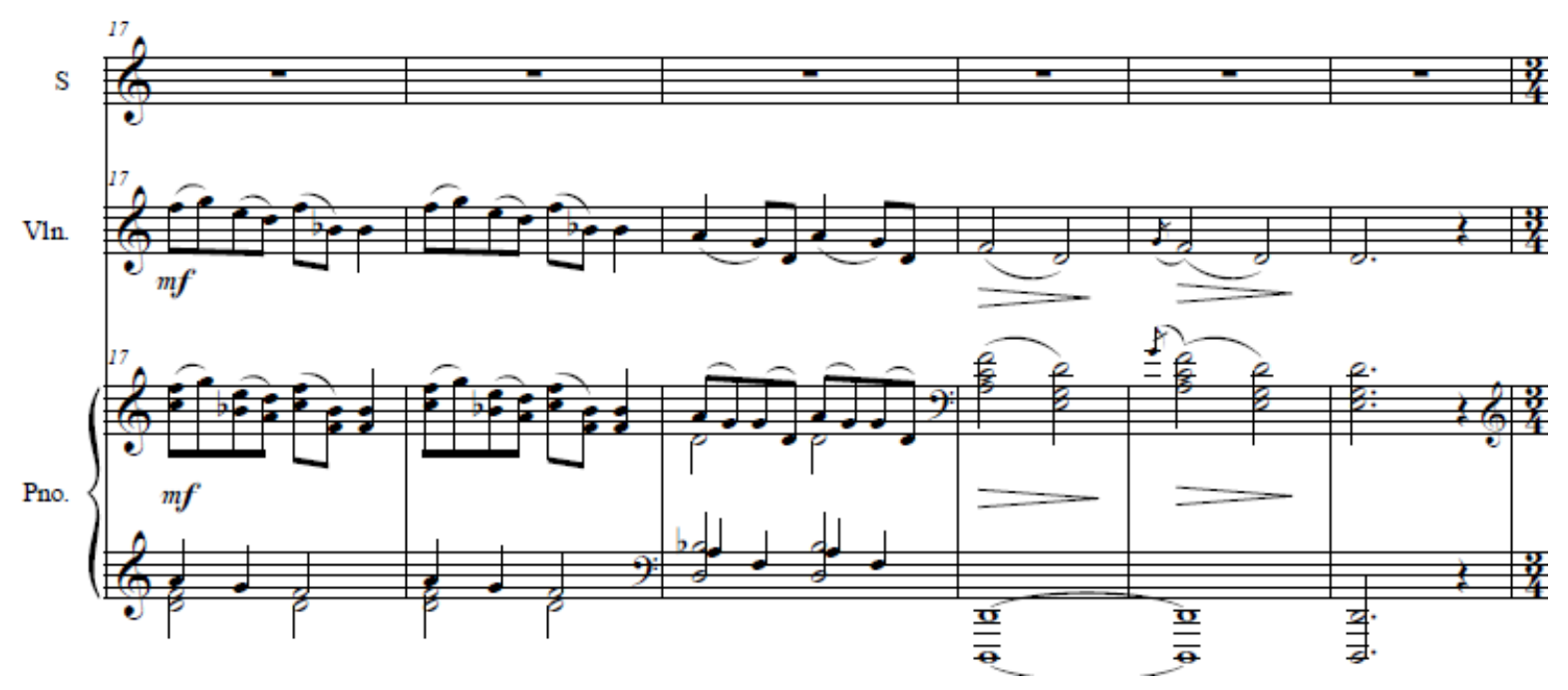

Since the right hand of the piano part is often used to double the soprano line ( $\mathrm{mm}$.

52-60, 65-73), the pianist must be aware of the syllabic stress and inflection of the text. As

Dr. Martin Katz has pointed out:

[...] if the voice part is performed with shape and the accompaniment has the same rhythm, we must replicate the shape exactly or imperfect ensemble will result. With or without linguistic fluency, as collaborators, we must know the inherent shape of a group of words to be able to predict and synchronize what happens at the piano with our inflecting partner. ${ }^{54}$

This is particularly important not only in terms of the search for the appropriate quality of sound and shaping of the phrase, but also in the correct way to highlight the melodic line with an expressive legato playing in the left hand (see Example 6.8).

\footnotetext{
${ }^{54}$ Marin Katz. The Complete Collaborator: The Pianist as Partner. (Oxford University Press, 2009), 23.
} 
Example 6.8. Jorge Humberto Pinzón. Scorpius, mm. 65-69.

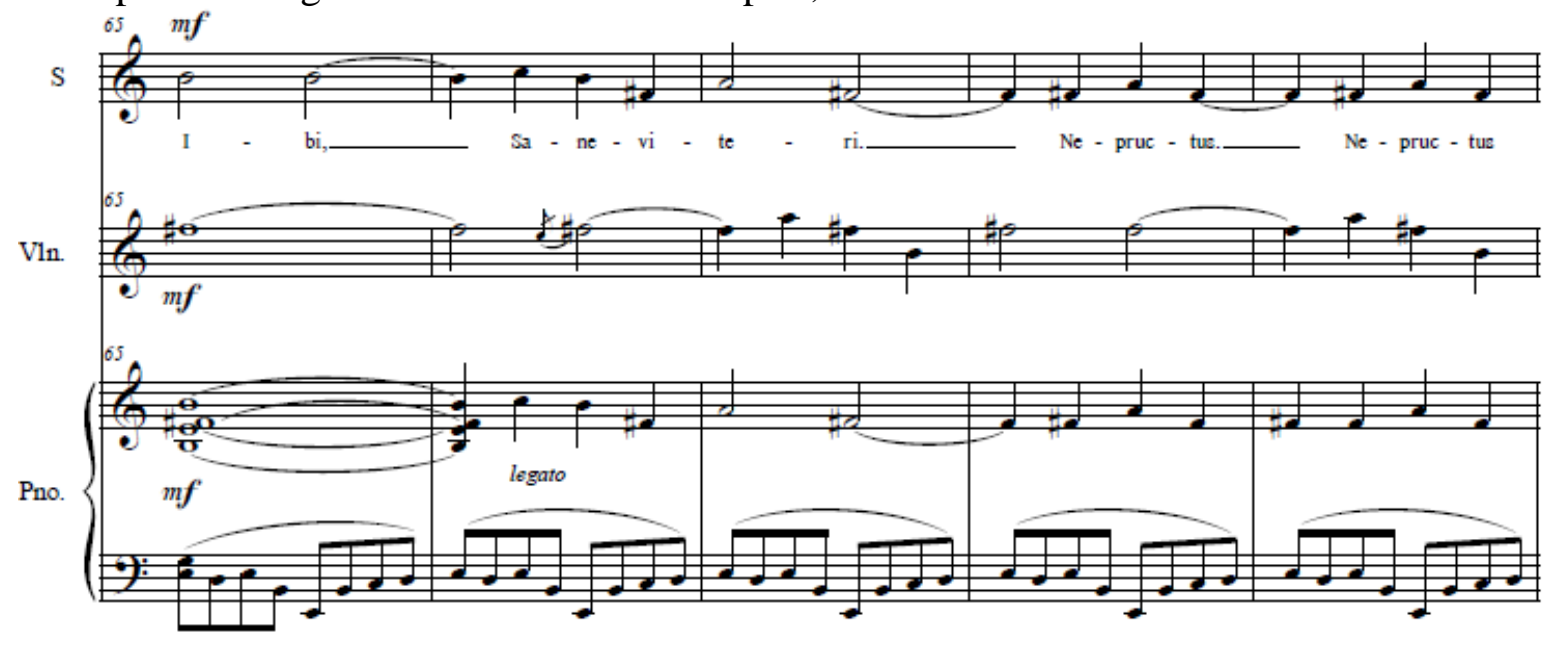

Changes of color in the violin part (muted effects) have to be observed and matched by a sensitive touch in the piano (Example 6.9).

Example 6.9. Jorge Humberto Pinzón. Scorpius, mm. 77-82

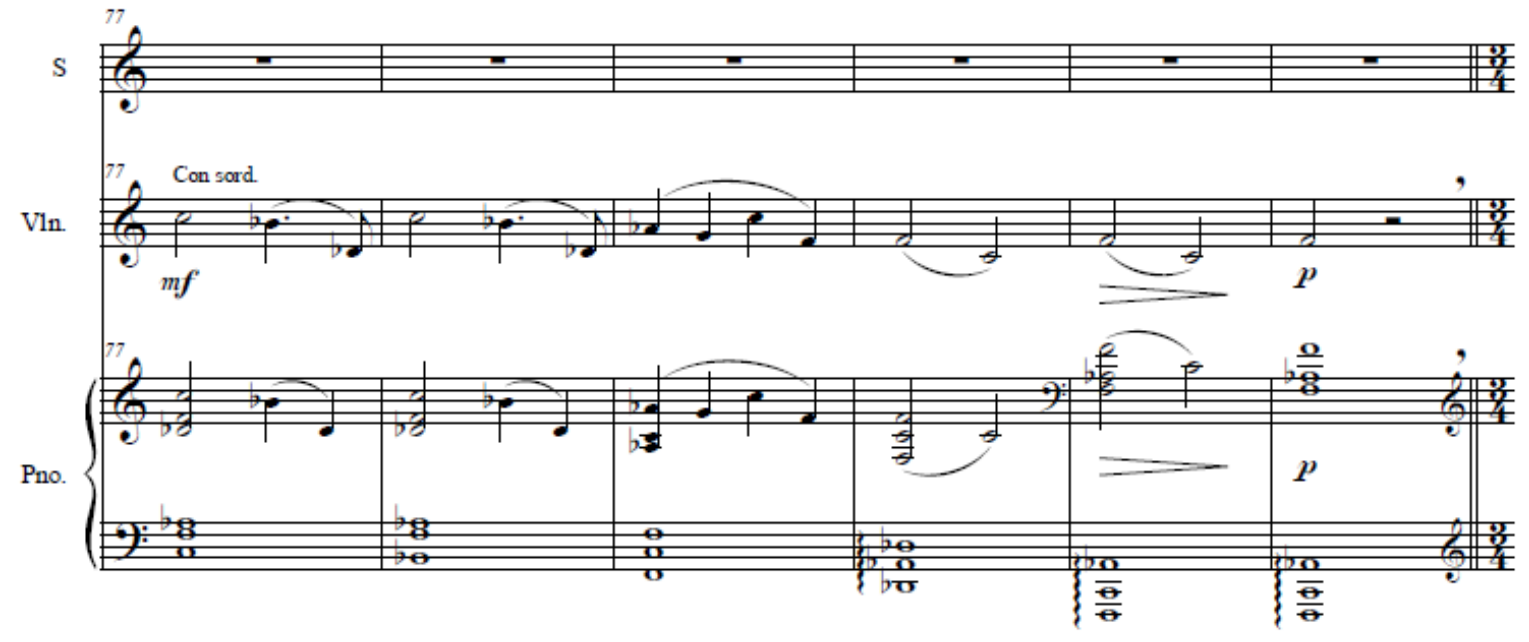

The piano part in this unusual ensemble requires an extreme sensitivity from the performer. The pianist has to be able to learn the text, establish the character, provide color, use a delicate legato articulation, and interact with both the singer and the violinist in order to highlight the expressive qualities of the piece. 


\title{
Chapter 7
}

\section{Paola Márquez}

\author{
Life
}

Mrs. Paola Márquez is a composer, psychologist and social worker. Throughout her interesting career she has been a leader in all three disciplines. Her music has been performed in Colombia and the United States. Both her artistic production and her research have achieved wide recognition in her country and abroad. She has received several commissions from important institutions and festivals. Márquez is perhaps one of the most promising Colombian composers in today's musical scene. Inspired by human psychology, her works combine art, music, and social issues.

Márquez was born in Cali, Valle del Cauca, in 1978. She graduated with a professional degree in psychology from Pontificia Universidad Javeriana in her hometown. In 1996, she published Mar Azul, a book of poems with prologue written by Jairo Aníbal Niño (1941-2010), one of the outstanding figures of Colombian literature.

Later, she moved to Bogotá to study music composition with Jorge Humberto Pinzón at Fundación Universitaria Juan N. Corpas. She obtained her Bachelor of Music degree summa cum laude, as well as a research first prize for her project "An Examination of Juan N. Corpas University Ear Training System as an Integrated Program, from a Learning Science Perspective”, in 2008. The same year she published this work in Saccom Magazine, and presented it at the Society for Music Education Psychology Research in Córdoba, Argentina. 
In 2008, Márquez traveled to the United States to pursue graduate studies. She earned her master of music degree in composition and theory from Syracuse University in 2011, as a student of Dr. Daniel Godfrey. Other studies in composition included lessons with Beatrice Baranzzoni at the Conservatorio di Udine in Italy in the summer of 2009. Later she was awarded the Eleanor Cranefield Scholarship at the University of Michigan at Ann Arbor, where she graduated in 2014 with a master's degree in social work.

Currently, Márquez lives in Michigan. She has worked as adjunct professor at Syracuse University and as music assistant for the Musica Mestiza Project led by composer Gabriela Frank. She has been composer in residence at Pelee Island Music Festival in Canada, Ruth Ellis Foundation, Detroit Children's Choir, Imagine and Syracuse Children's Chorus, and the Society of New Music, among others. Currently she works as an executive Program Coordinator at the Detroit Children's Choir, ${ }^{55}$ and participates in multiple social and musical projects in Michigan.

Márquez has composed for different ensembles. Her catalog includes solo, vocal, orchestral, and chamber music. She has collaborated with celebrated Russian violinist Artur Kaganovskiy (who recorded her piece Voice of Silence for solo violin in 2009), and with French filmmaker Boris Wexler for his movie Our Fathers (2011). She was awarded the Honorable Mention Citation in recognition of performance and achievement in the “International Music Prize for Excellence in Composition” in Greece in 2011.

\footnotetext{
55 “Detroit Children's Choir Paola Marquez Composer Spring Concert 2014”, YouTube video, 1:09, posted by Paolammgmusic, February 23, 2016. https://www.youtube.com/watch?v=gl5ppo7tuac
} 


\section{Compositional Style}

Composer Paola Marquez's style of composition is closely related to her deep understanding of human psychology. Often she explores the instrumental forces to create expressive effects. Although she has a preference for the use of a tonal harmonic language, sharp dissonances constitute a distinctive characteristic of her works.

Márquez has decided to incorporate a wide variety of compositional techniques into her style. Although she has the tendency to prefer a more universal language, veiled references to traditional Latin American music occasionally occur in her compositions. Her music is rhythmically rich, with frequent time signature changes and displacement of accents; however, a Colombian national accent or "flavor" is not overemphasized on her writing. This conscious distance from the tradition is perhaps one of the features that differentiates her from most of the Colombian composers of art music in her generation.

It is not surprising to find frequent associations between the instrumental colors and the states of the mind. Music in this case is not only music, but a conglomeration of experiences, ideas, and artistic creation. The human brain and the human emotions have been endless sources of inspiration for the composer. Silence (or what happens inside the human brain in the middle of a silent environment) is a recurrent subject in her pieces. As a matter of fact, her music has expressive qualities that reflect different states of the mind. ${ }^{56}$

\footnotetext{
56 "Paola M. Marquez", Pmmarquez.snappages.com, accessed April 02, 2017, http://pmmarquez.snappages.com/.
} 
The diversity of the performers and ensembles with which Márquez has collaborated, have been determinant in delineating her style. Her work encompasses a considerable variety of styles, forms, textures, instrumentations, and meanings, and perhaps the word "adaptability" could be used to explain and summarize its most important attributes. 


\section{List of Works}

- Canción de Cuna for mezzo-soprano and piano (2000)

- Pléyades for two sopranos and piano (2001)

- Noches de Luna for tenor and piano (2005)

- Deidades Freiya for string quartet (2006)

- Deidades Kwanyin for string quartet (2006)

- Deidades Oya for string quartet (2006)

- Gestalt for solo piano (2007)

- Hablándole al Silencio for violin and piano (2007)

- Pequeña Suite para un Gatito (2008)

- Gomer for soprano and piano (2009)

- Autumn burns for soprano and piano (2009)

- Silence for solo cello (2009)

- Cygnus 1 for orchestra (2009)

- Cygnus 2 for orchestra (2009)

- Cygnus 3 for orchestra (2009)

- $\quad$ Arise The Dreams of Thee for tenor and piano (2009)

- We Need More Lemon Pledge for jazz ensemble (2009)

- $\quad$ Sick Rose for mezzo-soprano and piano (2009)

- Voice of Silence for solo violin (2009)

- Into the Silence for violin, clarinet, and piano (2010) 
- Our Littles for solo piano (2010)

- Monarch for piano, violin and cello (2011)

- Efrain for baritone (2012)

- Dueling Cellos for two cellos (2012)

- Once Upon a Time for Orff ensemble (2012)

- Vision of Peace for chorus, violin, oboe, cello, and African drums (2012)

- Tree House Suite for soprano, oboe, violin, viola, and cello (2012)

- Tree House Round Trip for soprano, oboe, violin, viola, and cello (2012)

- I am love for children's choir (2013)

- Voices for string quartet (2014)

- Trio for violin, clarinet, and piano (2015)

- Kypros for orchestra (in progress) 


\section{"Into the Silence"}

An Overview of the Work and a Collaborative Pianist's Perspective

The trio Into the Silence for violin, clarinet, and piano was composed by Paola Márquez in 2010-11. The work was premiered by faculty members of Syracuse University at the Setnor Auditorium in Syracuse, New York, on March, 2011. The performers were violinist Edgar Tumajyan, clarinetist Baptiste Arnaud, and pianist Kathleen Hancock. In January 2012, Márquez received an Honorable Mention Citation at the "International Music Prize for Excellence in Composition 2011" by the National Academy of Music in Greece. The score has not been commercially published; however the world premiere of the piece was recorded and the composer has made this recording available on the internet. ${ }^{57}$

This type of chamber ensemble is quite unusual. In fact, the number of pieces composed for this combination of instruments in the twentieth century is fairly limited. Although it is true that composers like Stravinsky, Berg, Khachaturian, Ives, Milhaud, Poulenc, Khachaturian, and Bartók contributed to the literature of pieces for violin, clarinet, and piano, most of the repertoire for this ensemble has been composed recently.

Márquez has enlarged the repertoire for these instruments with two works: Into the Silence (2011), and Trio (composed in 2016 and premiered by the Khemia Ensemble in February, 2017, at the McIntosh Theater of the University of Michigan). Into the Silence is an episodic work in one movement. An average performance of this piece takes approximately seven minutes. The piece is structured as a ternary form, and is inspired in what happens inside the human mind when there is total silence (meditative state). The main motive of a descending whole step followed by an ascending half step (A-flat - G-flat

\footnotetext{
57 "Pmmarquez", SoundCloud, accessed April 02, 2017, https://soundcloud.com/pmmarquez.
} 
- G natural) in mm. 1 and 2 is the basis for the melodic and harmonic construction of the piece. As a matter of fact, this motive permeates the whole piece.

In concordance with the compositional approach of the composer, in this piece the instruments highlight the diversity of colors that represent the different emotional states of the human being and also the way these emotions are connected to the thoughts. The rhythmic treatment depicts the constant chains of thoughts which never stop. This effect of perpetual motion is achieved by the permanent concatenation of motivic ideas between all the instruments.

Although the composer is not a concert pianist herself, her understanding of the possibilities of the piano is astonishing. In fact, she develops an idiomatic writing for the instrument which challenges not only the technical skills of the performer, but also tests his ability to match the colors, articulations, and rhythms of the violin and the clarinet. In other words, one of the difficulties of this piece is the search of a perfect balance between the sonorities of all three instruments. An abundance of unison passages is a clear example of the importance of this critical aspect in the performance.

Unlike her Trio (2015), in which some influences of Latin American rhythms appear, in Into the Silence, typical rhythms or dances are less evident; however, the work is full of rhythmic complexities, especially syncopations and irregular displacement of accents.

The piano is responsible for setting the mood and for presenting the main motivic idea at the beginning. An anxious fast passage, with parallel motion in both hands, opens the piece. The articulation here, non legato, is critical to establishing the character (see Example 7.1). 
Example 7.1. Paola Márquez. Into the Silence, opening.
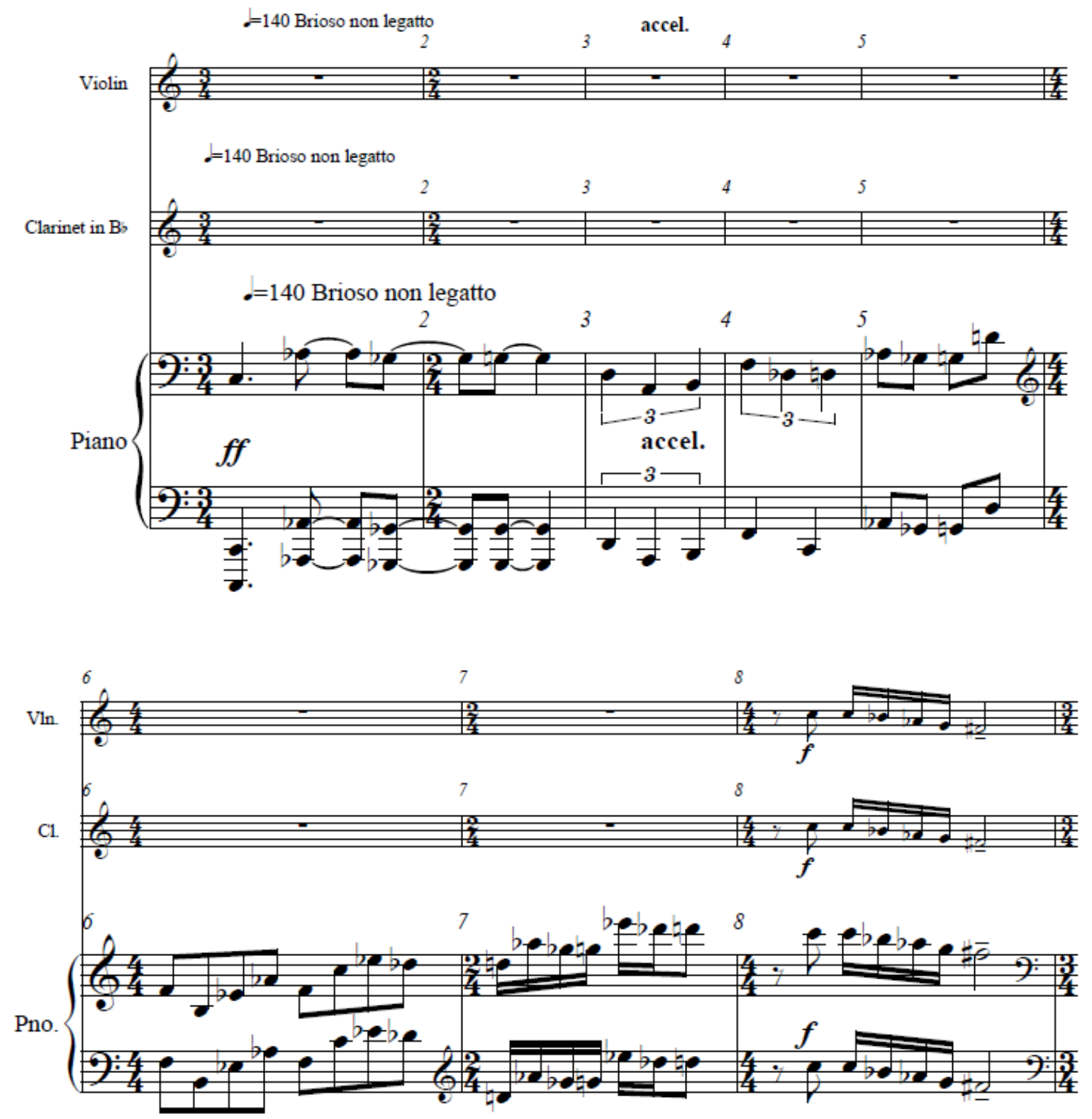

The pianist is required to keep a clear rhythmic beat, while the other two

instruments present their themes in syncopation. An important figure occurs in m. 20,

where the piano combines triplet figures against eight-notes. Clarity is very important here, for the other instruments need to hear the down beats clearly to play their syncopations effectively (Example 7.2). 
Example 7.2. Paola Márquez. Into the Silence, mm. 19-23.

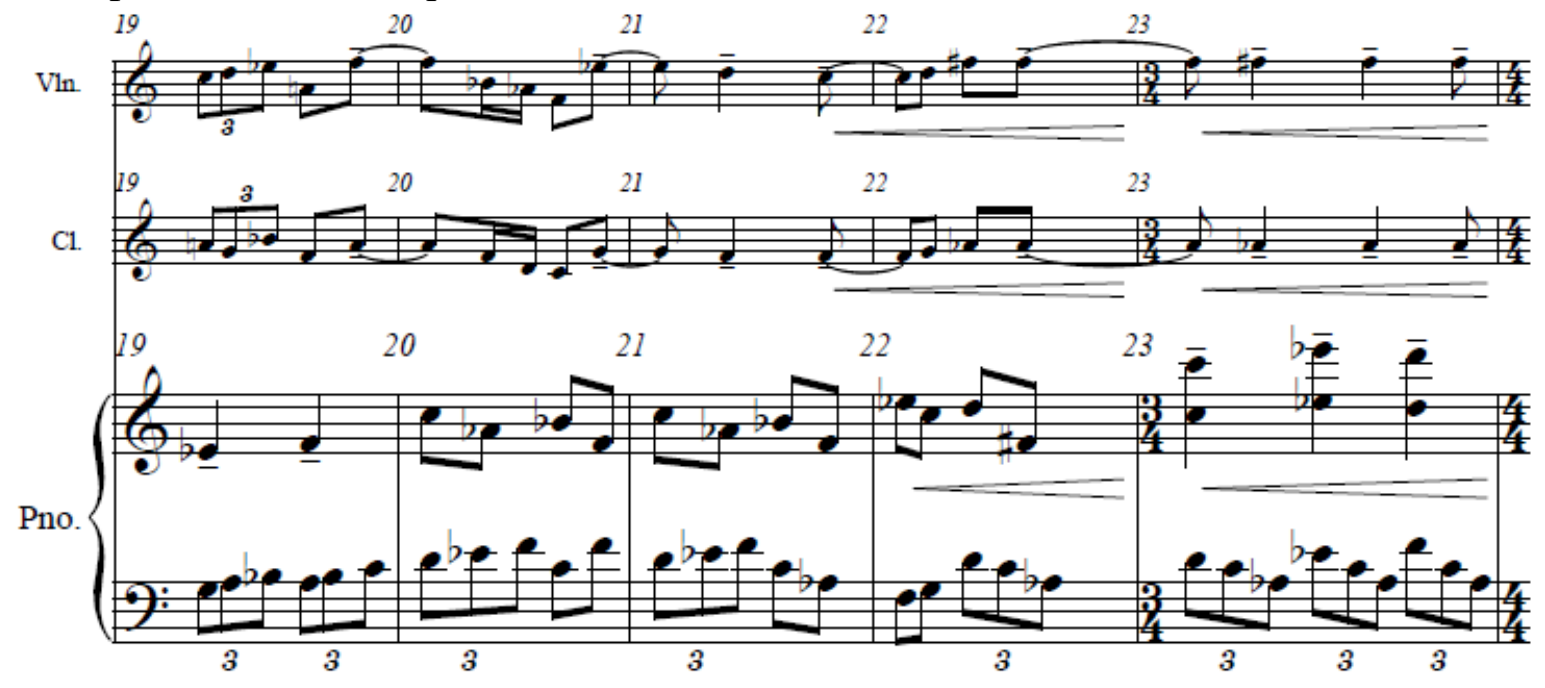

In this piece, the melodic lines pass from one instrument to another and motivic imitation is characteristic. For this reason it is important for the pianist to listen to the motives in the other instruments to make clear the hierarchic organization of all the lines in the texture, especially when the rhythm is displaced and not replicated exactly in the same way (see Example 7.3). 
Example 7.3. Paola Márquez. Into the Silence, mm. 24-31.
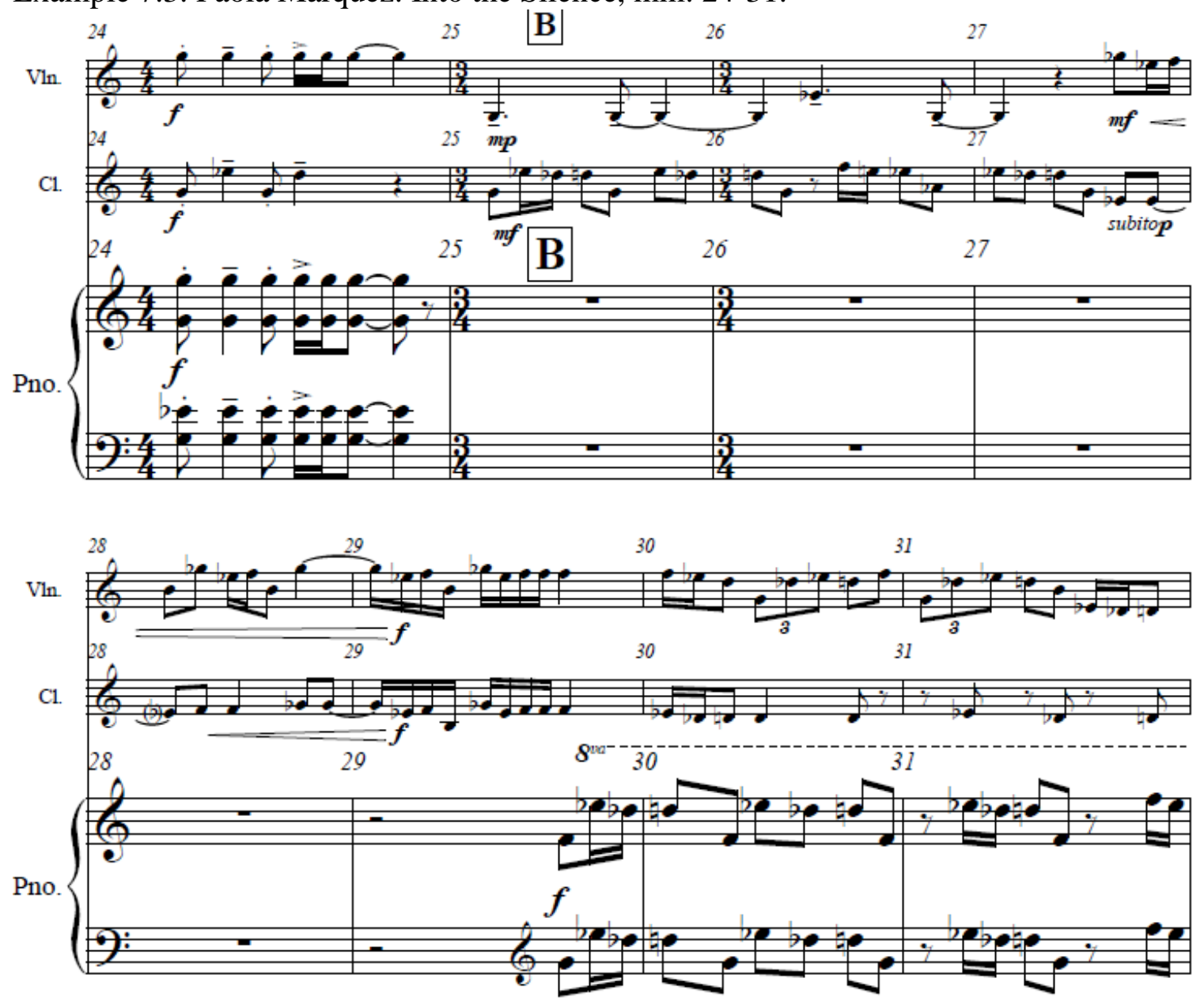

Placement of the accents in unexpected parts of the measure is characteristic. The piano here is treated almost as a percussion instrument, giving variety and supporting the entrances and conversation between the violin and the clarinet. Challenging rhythmic accentuation requires particular attention as well (Example 7.4). 
Example 7.4. Paola Márquez. Into the Silence, mm. 57-62.

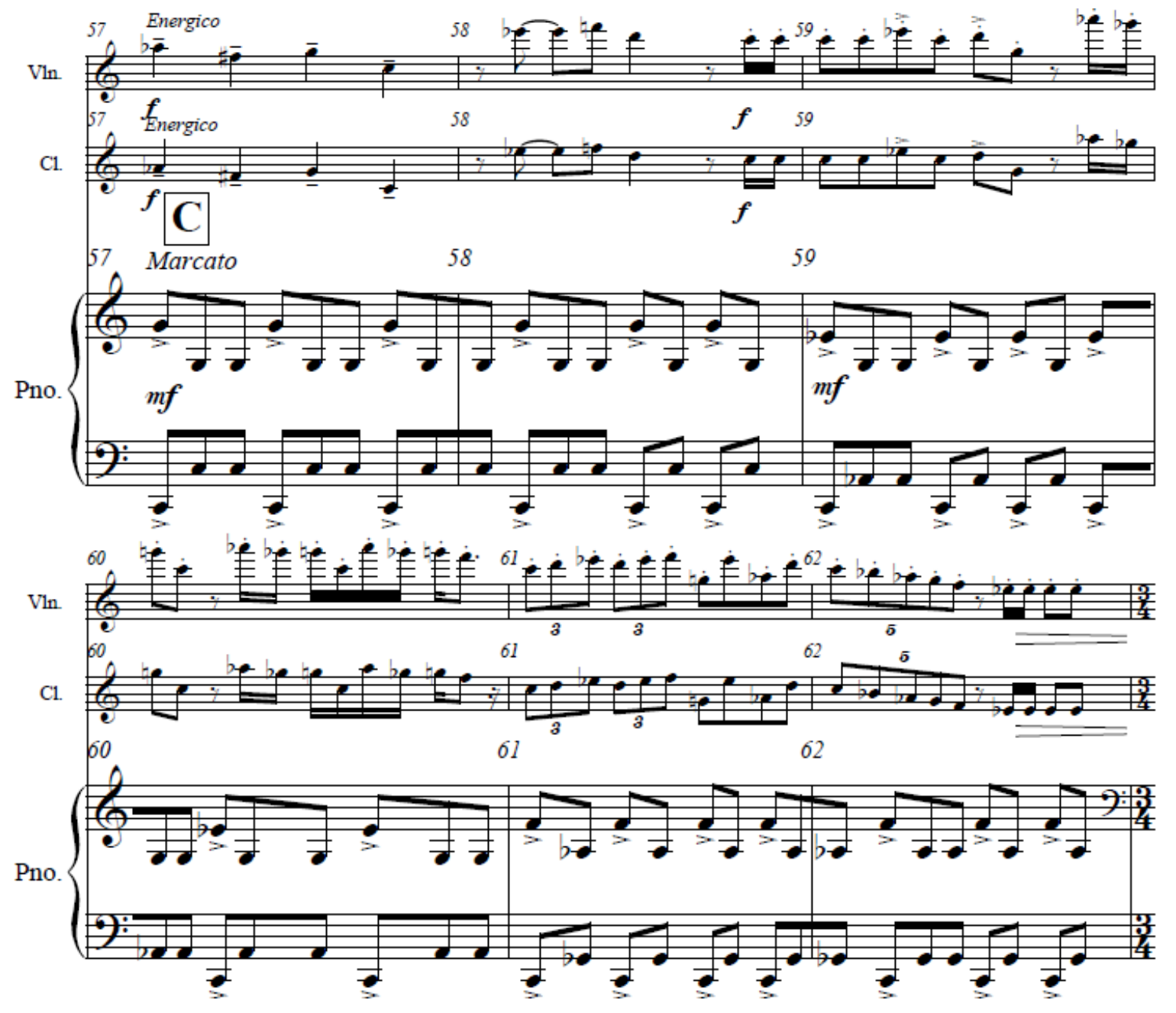

The beautiful piano interlude in the middle section (mm. 85-96) is full of varied colors and dynamic changes. Marked legato espressivo, this contrasting section should be approached with a cantabile sound and a delicate shaping of the phrases, and also with more flexibility in the rhythm (see Example 7.5). This restrained atmosphere should be kept for the entire next section, marked vals espressivo, starting in m. 97. 
Example 7.5. Paola Márquez. Into the Silence, mm. 83-92.
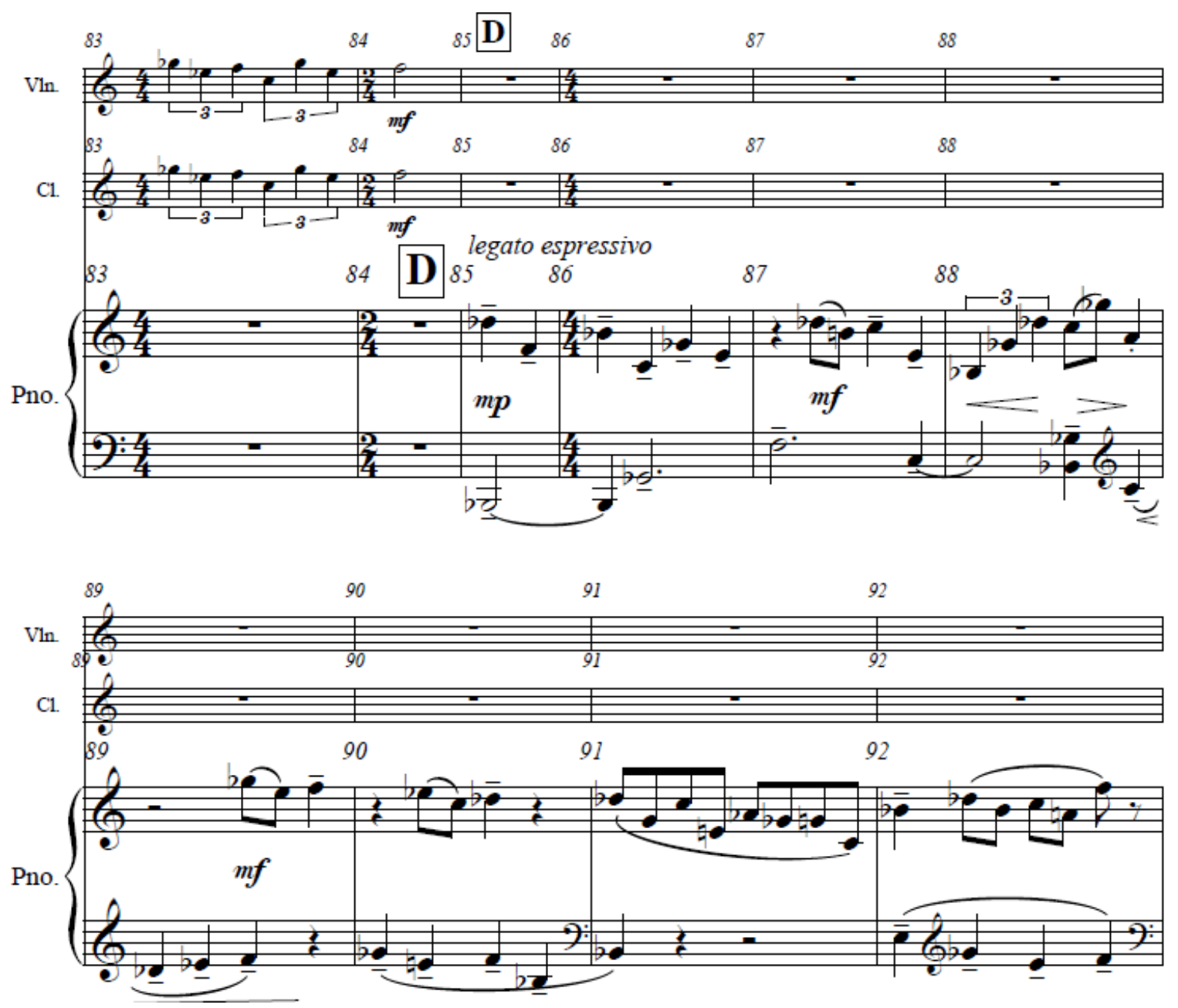

Since the percussive qualities of the piano are explored in this piece, it is important

to use the pedal very carefully. Staccato articulation is characteristic. Long staccato

passages in the high register with repeated notes also need to be heard clearly (mm. 174-

183) (see Example 7.6). 
Example 7.6. Paola Márquez. Into the Silence, mm. 176-183.
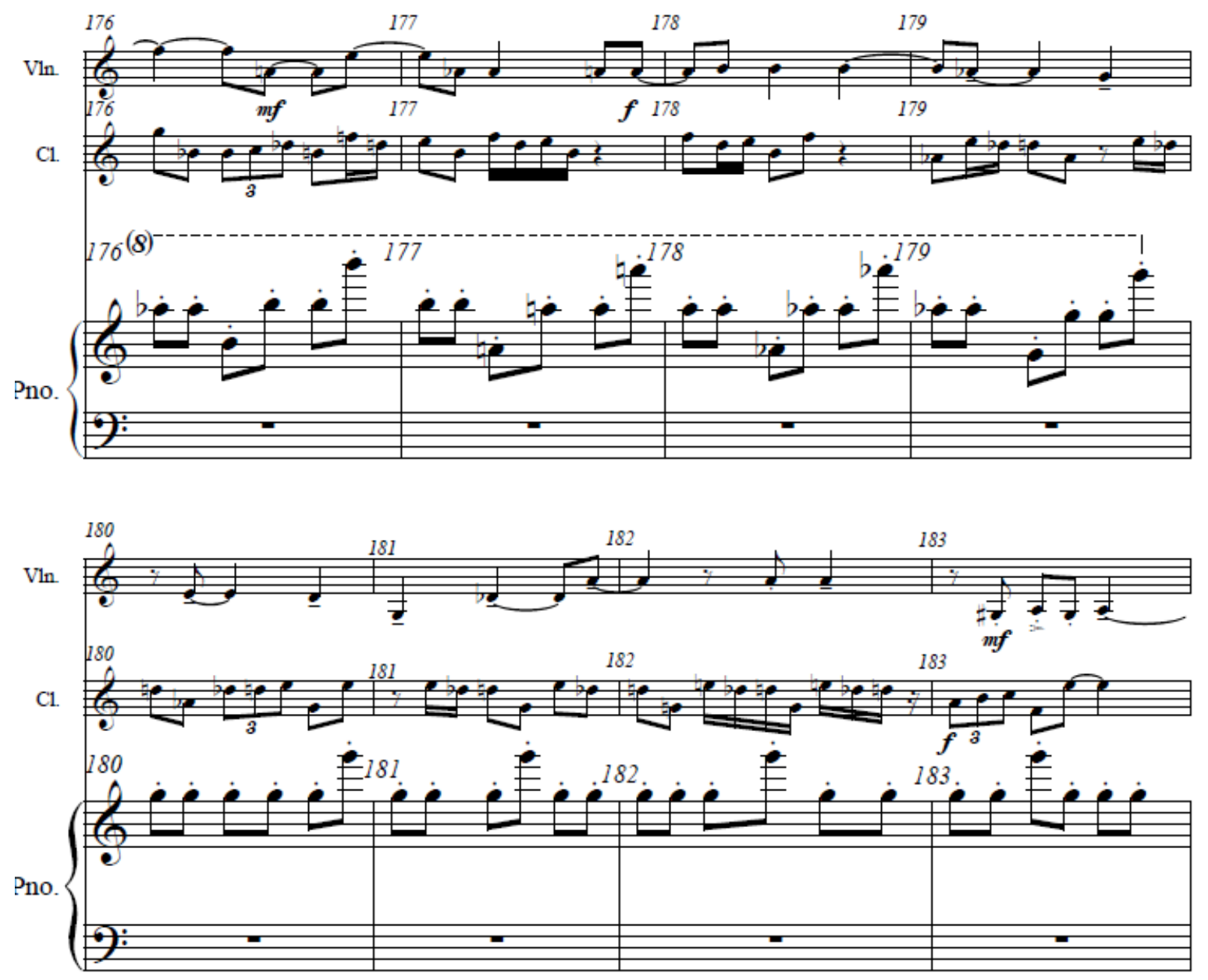

The same applies for measure 218, where, after a sudden dynamic change, the piano presents the main motivic element which will be imitated in the other instruments (Example 7.7). 
Example 7.7. Paola Márquez. Into the Silence, mm. 217-221.
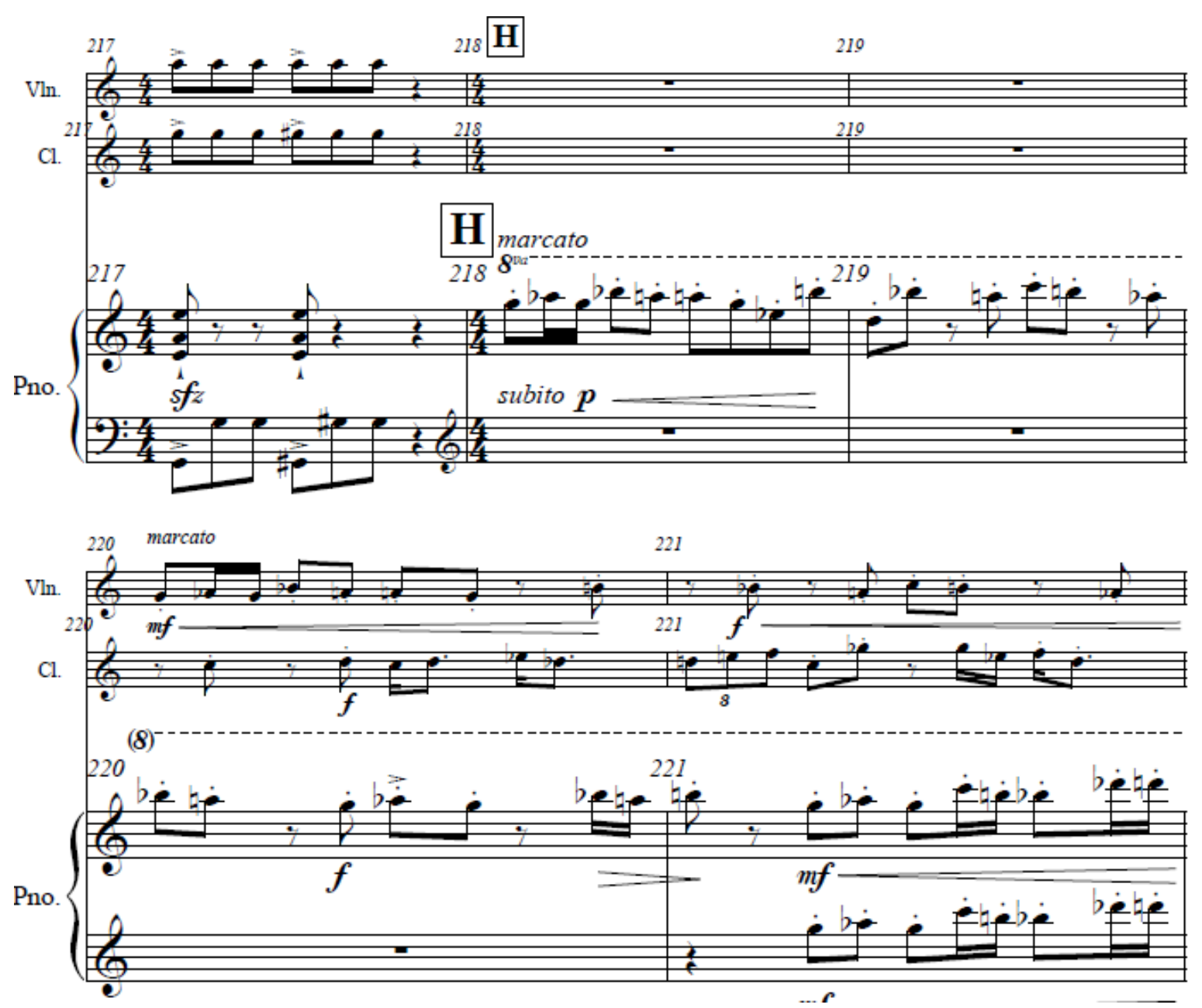

Intricate syncopations and rhythmic irregularities are emphasized at the end of this piece in the drive toward a huge $f f f$ climax. Indications such as marcato, $f f, s f z$, crescendo, and accents have to clearly balanced and controlled to maintain the tightness of the ensemble and achieve a satisfactory ending (see Example 7.8). 
Example 7.8, Paola Márquez. Into the Silence, mm. 224-228
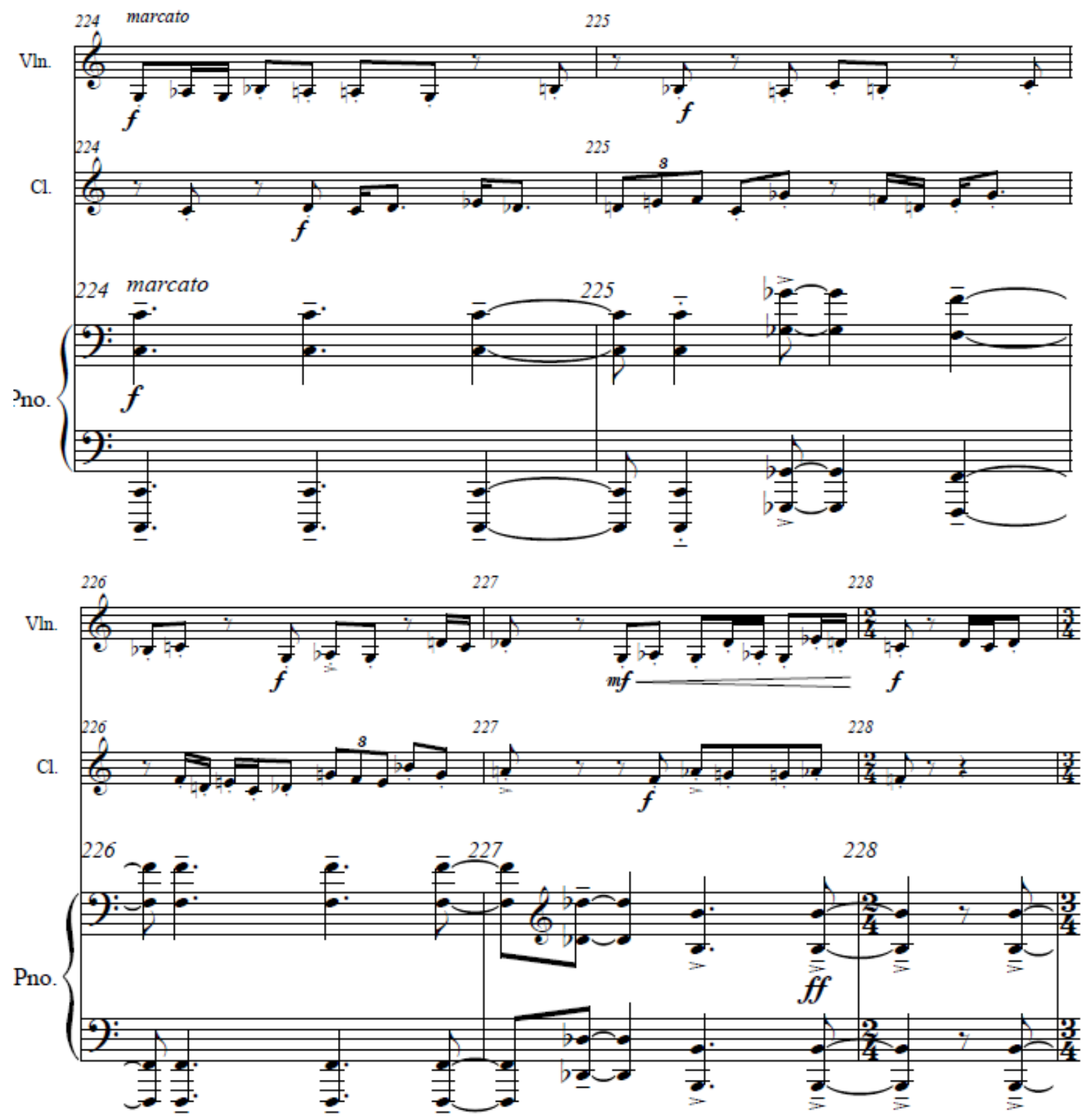

Into the Silence reveals a universe of possibilities for the collaborative pianist. He or she will benefit greatly from studying this piece. Variety in articulation, rhythmic patterns, dynamics, flexibility and stability of tempos, diverse characters, and a deep understanding of the sounds of the clarinet and the violin, are among the interesting elements that could enrich the performer's language. 


\section{Chapter 8}

\section{Germán Darío Pérez}

\section{Life}

Composer and pianist Germán Darío Pérez is a preeminent figure in Colombian music. His works represent the confluence of two languages: typical folk music and academic European traditions. The ability to combine his personal mastery of typical Colombian-Andean rhythms with the sophistication of scholastic writing, allowed him to develop a distinct compositional style. He has manipulated the traditional language of Colombian-Andean folk music, transforming it into a universal form of artistic expression. The originality of his writing explains his phenomenal success as a composer and as a performer.

He was born in Bogotá, in 1969, into a family of musicians. He started to play the piano at the age of four and soon discovered that he had perfect pitch. As a child, he was mostly influenced by traditional Colombian music, especially by the works of composer Oriol Rangel (1916-1977). This interest in folk music was crucial for his understanding of the cultural heritage of his region: structures, forms, and melodic and harmonic elements of this music were rapidly incorporated into his first compositional attempts. He began his formal studies at Academia Francisco Cristancho with Colombian pianist Ruth Marulanda. Between 1982 and 1996, he studied at the Universidad Nacional de Colombia with Mireya Arboleda and Pablo Arévalo.

As a teenager, Pérez started to compose regularly and participated in several Colombian music-composition competitions, obtaining a first prize in 1985 at the Concurso 
Jorge Villamil Cordovez, at the age of 16. At the same time, he started to incorporate a more elaborate musical style of writing (altered harmonies and diversity in the rhythms, for example) into his compositions. His experimentation with the folkloric musical language of his country opened the spectrum of possibilities for new composers of Colombian music who were interested in the search for alternate ways to deviate from the conventions of the tradition. $^{58}$

In 1986 he founded the Trío Nueva Colombia, an ensemble of piano, tiple, ${ }^{59}$ and double bass, with Colombian musicians Ricardo Pedraza, and Mauricio Acosta. This unusual combination of instruments allowed the composer to take his experiments and discoveries one step further. His compositions, his direction, and his adventurous arrangements, combined with the virtuosic and expressive qualities of his colleagues, resulted in a very successful collaboration that continues until today. The trio has been awarded several national and international prizes, and has been recognized as one of the most important ensembles of the so-called "New Andean-Colombian Music.",60

\footnotetext{
58 “Germán Darío Pérez Vida y Obra”, YouTube video, 28:23, posted by Canal de Deberesydelicias, June 18, 2016. https://www.youtube.com/watch?v=b42WdnFUwzM

${ }^{59}$ The Colombian Andean tiple is slightly smaller than the guitar, with twelve strings grouped in four courses of triple metal strings tuned to the same pitches as the four upper strings of the guitar, but with the middle string of the three lowest courses tuned an octave lower. John M. Schechter. "Tiple." Grove Music Online. Oxford Music Online. Oxford University Press, accessed April 3, 2017, http://www.oxfordmusiconline.com/subscriber/article/grove/music/47557.

${ }^{60}$ Eliécer Arenas Monsalve, “Texto Integral Escrito para el Monográfico del Maestro Germán Darío Pérez Organizado por la Biblioteca Luis Ángel Arango" November 22, 2010 (2:33 p.m.), comment on Doris Salcedo "El Oído que Seremos" (blog), http://eloidoqueseremos.blogspot.com/2010/11/texto-para-elmonografico-del-maestro.html
} 
With his trio, Pérez received a huge number of awards and recognitions in the vast majority of competitions and festival of Colombian music. ${ }^{61}$ After more than 20 years of an intense career as composer, arranger, and performer for this group, during which they played hundreds of concerts in more than 15 countries of America and Europe, in 2009, Pérez decided to found a new ensemble, Síncopa-Cinco, with two flutes, cuatro (a small four-string plucked lute descended from the Spanish vihuela), ${ }^{62}$ piano, and electric bass. With this group, he could explore more possibilities of timbre and color, and also expand the textures. Juan Carlos Contreras (cuatro), Ricardo Zapata (electric bass), Sandra Sánchez (flute), and Felipe García (flute) are the members of this group.

Pérez has received 23 first prizes in composition. In 2010 and 2013 the Banco de la República organized monographic concerts in homage to the composer at the prestigious Sala de Conciertos Luis Ángel Arango recital hall, an unprecedented event for a composer of traditional music.

Since 2011, Pérez has participated in several projects of promotion and divulgation of Colombian-Andean music, such as the Festival Internacional Latinoamérica de Concierto, among others. In 2012 he obtained his Bachelor of Music degree from the Universidad Distrital Francisco José de Caldas (Academia Superior de Artes de Bogotá). He has served as faculty member at the Universidad Pedagógica Nacional and at the Universidad Nacional de Colombia.

\footnotetext{
${ }^{61}$ Olga Cecilia Pérez, "Album Mi camino. Trío Nueva Colombia 30 años," Indiegogo, December 11, 2016, accessed April 02, 2017, https://www.indiegogo.com/projects/album-mi-camino-trio-nueva-colombia-30anos\#/.

62 "Cuatro." Grove Music Online. Oxford Music Online. Oxford University Press, accessed April 3 , 2017, http://www.oxfordmusiconline.com/subscriber/article/grove/music/06925.
} 
At the time of completion for this research paper, Pérez is working on the commercialization of a new album, Mi Camino, with his Trio Nueva Colombia, in celebration of his career, which spans 30 years. The album was recorded in the United States in June 2016 under the Hoot/Wisdom Recordings label at Florida Atlantic University in Boca Raton.

Pérez has composed for a wide variety of ensembles and for soloists as well. His works are constantly performed in Colombia and abroad. He has collaborated also with esteemed classical and folk musicians. His music has been heard in important venues such as the Southbank Centre in London and Carnegie Hall in New York, among many others. 


\section{Compositional Style}

Germán Darío Pérez's musical language could be described as the amalgamation of the Andean sounds of Colombia and the academic techniques of European music. As a matter of fact, stylistic boundaries become blurred in his works. This music is the result of a fascinating coexistence of tradition and experimentalism. In fact, from a broad point of view, Mr. Pérez's music clearly demonstrates that new Colombian artistic creations are essentially the product of constant transformations.

The works of Pérez are clearly influenced by Colombian bambuco. He has conceived the impressive rhythmic richness of this particular folk dance not only as an immense universe of possibilities, but also as the point of departure for wide experimentation. His music is not an opposition or reaction to the past, but rather a conscious assimilation and a gradual incorporation of learned techniques into a new individual language.

The most important influences in the formation of his style are: The traditional instrumental bambuco played by tiple (which he heard at home as a child), the transcriptions and adaptations of bambuco by composers Oriol Rangel (particularly those he made for the Nocturnal Colombiano ensemble) and Manuel J. Bernal, the teaching of Colombian pianist Ruth Marulanda, and his admiration for the language of European composers of academic music.

According to professor Manuel Bernal Martínez, who wrote the program notes for the second monographic concert dedicated to de composer at the Sala Luis Ángel Arango in 
2013, although some of the altered harmonies he uses have been frequently associated with jazz, there is not a direct influence of this particular genre in his music. The melody and its different presentations are conceived as a fundamental element of his compositional style. The forms he uses contrast with those of the Colombian-Andean traditional music, which are based on repetition (strophic). Frequently in his compositions, the opening sections reappear at the end of the pieces in a manner of A-B-A structures. A rigorous composer, his careful writing exemplifies why motivic connections are determinant as a method to unify his works and solidify the structure. ${ }^{63}$

\footnotetext{
${ }^{63}$ Manuel Bernal Martínez. "La música de Germán Darío Pérez," Issuu, accessed April 02, 2017, https://issuu.com/banrepcultural/docs/pdf_aprobado_german_dar_o_perez.
} 


\section{List of Works}

- Recuerdos (Bambuco) (1985)

- Locuras (Bambuco) (1987)

- Ancestro (Bambuco) (1988)

- Pa’ Juancho (Bambuco) (1989)

- Pitituya (Bambuco) (1990)

- Garrapatica (Bambuco) (1992)

- Un bambuco muy cortico para mi amiga que toca el clarinete (Bambuco) (1993)

- Insistime (Pasillo) (1994)

- $\quad$ Después de todo (Guabina) (1995)

- $\quad$ Ilusa (Danza) (1995)

- Minimito (Bambuco) (1995)

- Toña la Blanca (Pasillo) (1999)

- Seré papá (Pasillo) (2000)

- Suite Colombia for solo piano (2002)

- Tan Cerca pero tan lejos (Pasillo) (2002)

- Pa' los Palos (Guabina) (2005)

- Guabina y Caña for string quartet and tiple (2006)

- Bambina (Bambuco-Guabina) (2006)

- Celitos (Pasillo) (2008)

- Homenaje for bandola and piano (2009)

- La Gorda Marrana (Pasillo) (2009)

- Dospianazo No.1 for two pianos (2011) 
- El carrerón for bandola and mandolina (2012)

- León Cardona (Bambuco) (2012)

- Mi camino (Danza) for solo piano (2012)

- Don Giovanni...Parra (Bambuco) (2014)

- Artesano de poemas (Pasillo) (2015)

- Chilita (Pasillo) (2015) 


\section{"Dospianazo No.1"}

Overview of the work and a Collaborative Pianist's Perspective

The work Dospianazo No.1, subtitled Fantasía para dos pianos sobre tres motivos andinos colombianos: Bambuco, guabina y pasillo (Fantasy for two pianos on three Colombian-Andean motives: Bambuco, guabina and pasillo) was composed by Germán Darío Pérez in 2011. The piece was written as the composer's final graduation project at the Universidad Distrital Francisco José de Caldas in Bogotá. A typical performance of this piece lasts approximately seven minutes.

The work was included in the second monographic concert dedicated to Pérez at the Sala de Conciertos Luis Ángel Arango in 2013, in a program which included five other chamber pieces by the composer. The concert was part of a larger project which included not only a recording, but also a publication of all six works in the album called Germán Darío Pérez Salazar, Cinco Obras de Cámara with the patronage of the Orquesta Filarmónica de Bogotá for free distribution in Colombian libraries, centers of musical documentation, and universities. ${ }^{64}$ On that occasion the performers were Colombian pianist Mauricio Mayorga (piano II) and the composer himself (piano I). A recent performance of this work took place at the same venue by Colombian piano duo Unuma, formed by the young pianists Cintia Bonilla and Santiago Bertel, in August 2016.

It is not easy to find music for two pianos by Colombian composers in the $21^{\text {st }}$ century. With the exception of Amparo Ángel (b. 1945), who explored this type of ensemble in her work Coloquio entre Dos Pianos (2008), as well as Diego Vega in his

\footnotetext{
${ }^{64}$ Germán Darío Pérez Salazar, Cinco Obras de Cámara, Corporación Musicarte, Bogotá, 2013, CD and Music Score.
} 
Rhapsody (2012), Dospianazo No. 1 by Germán Darío Pérez is one of the few relevant pieces written recently for two pianos in Colombia.

In the $20^{\text {th }}$ century, celebrated Colombian composer Jaime León (1921-2015) had written Remembranzas (1963), a beautiful work that pays homage to popular Colombian pasillos and bambucos such as: Flores Negras, Malvaloca, Lejano Azul, and Brisas del Pamplonita. From a wide perspective, Pérez's work seems to be connected to Remembranzas.

Dospianazo No.1 exemplifies Pérez's more adventurous side. This ambitious work cites in a very particular way the Colombian-Andean dances mentioned in the subtitle. Although allusions to the folk rhythms are present, the composer prefers to use them not in the traditional, but in a manipulated form instead. This procedure of using indirect references to folklore is similar to what Argentinian composer Alberto Ginastera called a "Subjective Nationalism" when he described the works of his middle period:

Classic studies of Ginastera's music divide his creative production into three stylistic periods based on the composer's own criteria [...] In his second creative stage, termed 'subjective nationalism' (1947-57), he continued to employ an Argentine musical language within a tonal or polytonal setting, but alluded to vernacular elements in a sublimated form. ${ }^{65}$

Pérez's manipulations of the motivic elements consist of rhythmic displacements, inversion of the usual roles of bass/chord in the accompaniment, or juxtaposition of elements of different genres. These experimental procedures exemplify a more conceptual

\footnotetext{
${ }^{65}$ Deborah Schwartz-Kates. "Ginastera, Alberto." Grove Music Online. Oxford Music Online. Oxford University Press, accessed April 3,

2017, http://www.oxfordmusiconline.com/subscriber/article/grove/music/11159.
} 
approach by the composer, a procedure that can be found in his Suite Colombia (2002) for solo piano, but that is difficult to find in other pieces of his catalog. ${ }^{66}$

Compositional techniques such as two-bar rhythmic-harmonic modules, dense harmonies full of clashes, priority of the rhythm over the melodic material, long ostinato patterns, and extended transitions between sections, are characteristic of this piece.

The work begins with a bambuco rhythm in Piano II with the main melodic material in Piano I after four measures. After the repetition of the first section, the following part, starting at measure 39 , functions as a slow contrasting segment with prolonged chords, which leads towards a new section that presents a melody derived from the one at the beginning, although this time with a different pattern in the accompaniment: A guabina pattern (m. 65). ${ }^{67}$ In m. 81 , the music transforms suddenly into a pasillo, which ends in a big climax at $\mathrm{m}$. 98. The following section is an interesting "primitive" recapitulation of the main themes and genres with a rhythmic exploration of the lower register of Piano II. A reelaboration of all the themes and moods takes place, reaching a second climax in m. 168 . The bambuco-like theme of the beginning reappears in $\mathrm{m} .169$ and leads to a short coda that closes the piece.

The unusual ensemble, the sharp dissonances, the complexity in the rhythms, and the thick textures, differentiate this piece from other works and represent the academicexperimental side of the composer. The national "Colombian accent" here functions as the

\footnotetext{
${ }^{66}$ Manuel Bernal Martínez "La música de Germán Darío Pérez," Issuu, accessed April 02, 2017, https://issuu.com/banrepcultural/docs/pdf_aprobado_german_dar_o_perez.

${ }^{67}$ A genre typical of the departments of Santander and Tolima, primarily used for singing coplas rather than for dance accompaniment. It is in triple metre and has a medium tempo, with frequent sections of a slower tempo in free rhythm. Gerard Béhague, et al. "Colombia." Grove Music Online. Oxford Music Online. Oxford University Press, accessed April 3,

2017, http://www.oxfordmusiconline.com/subscriber/article/grove/music/06137.
} 
point of departure for an adventurous piece which reveals the possibilities of the piano ensemble, encouraging other Colombian composers to explore the full potential of the two instruments.

In Dospianazo No. 1, both pianos are treated as equal partners in the ensemble. The level of difficulty is essentially the same for the two instruments. There is no predominance of one piano part over the other. In fact, the piece is conceived in a way that the material is all connected, distributing melodies and accompaniments equally. Therefore it is very important that the pianists learn both Piano I and Piano II parts, to acquire a better understanding of the elaboration.

Although the melodic treatment is highly sophisticated, the emphasis will always be on the rhythmic richness of the accompaniments. The bambuco pattern at the beginning, for example, could be studied silently by tapping the rhythm on the lid of the piano as a way to clarify the rhythmic accentuation. In this type of rhythm, it crucial to understand the role of the eighth rest (see Example 8.1).

Example 8.1 Germán Darío Pérez, Dospianazo No. 1, opening.

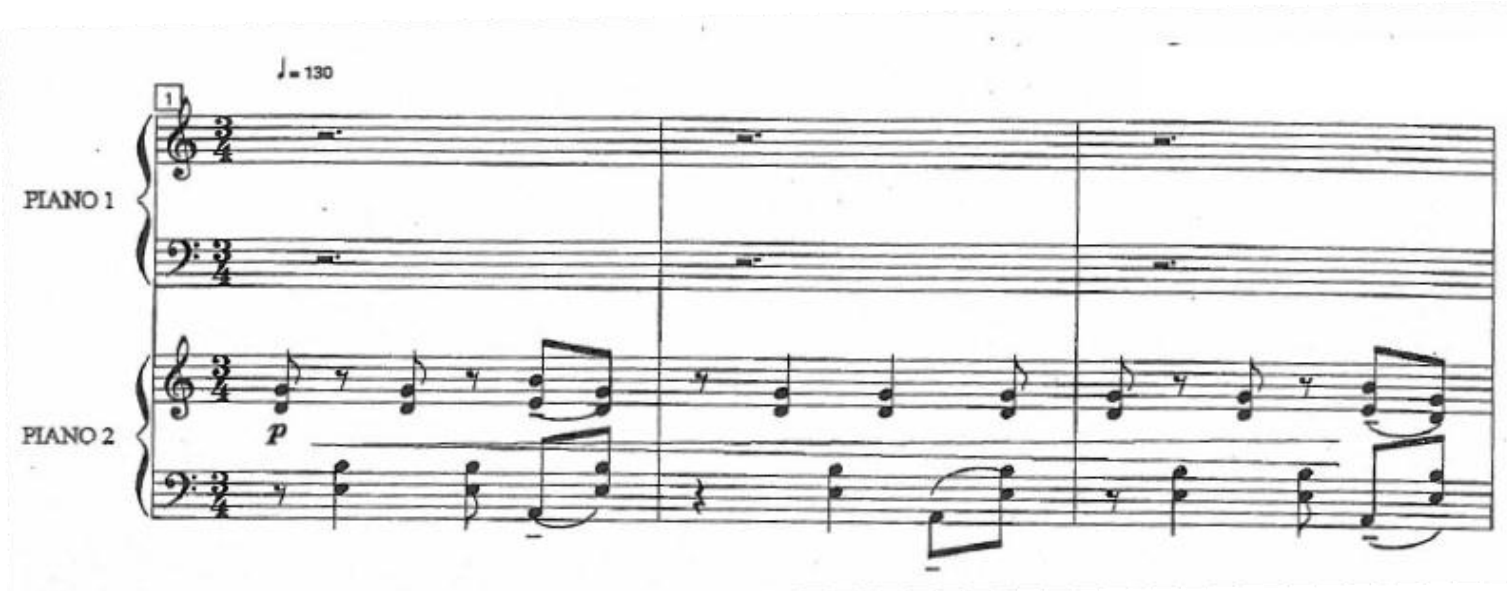


Since the melodic lines are often doubled in octaves in the right hand, a clear voicing that balances the sound towards the top is crucial for a clear projection of the lines, especially with all the rhythmic syncopations and articulations that happen simultaneously (see Example 8.2).

Example 8.2 Germán Darío Pérez, Dospianazo No. 1, mm. 10-12.

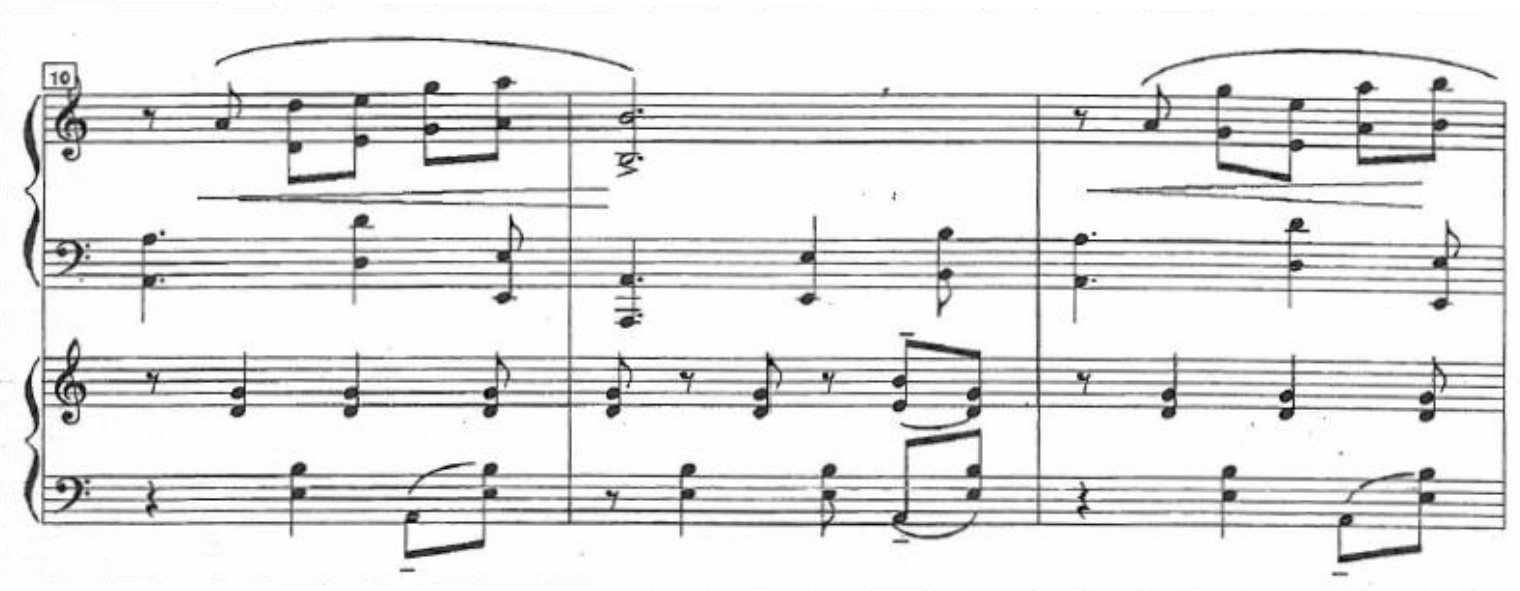

In the opening, the melody is played by Piano I, and the accompaniment by Piano II; however, in measure 23, the roles change. These details are important because they encourage both performers to unify their sounds and to listen closely for balance.

Furthermore, the fact that the composer writes very specific dynamic markings for both instruments throughout makes it challenging for the performers to identify clearly the different layers of the texture.

In the pre-transition section in mm. 35-38, both pianos have the melody in the right hand and the accompaniment in the left hand. A helpful way to practice passages like this would be to isolate the lines and play both right hands together, or both left hands (see Example 8.3). 
Example 8.3 Germán Darío Pérez, Dospianazo No. 1, mm. 33-38.
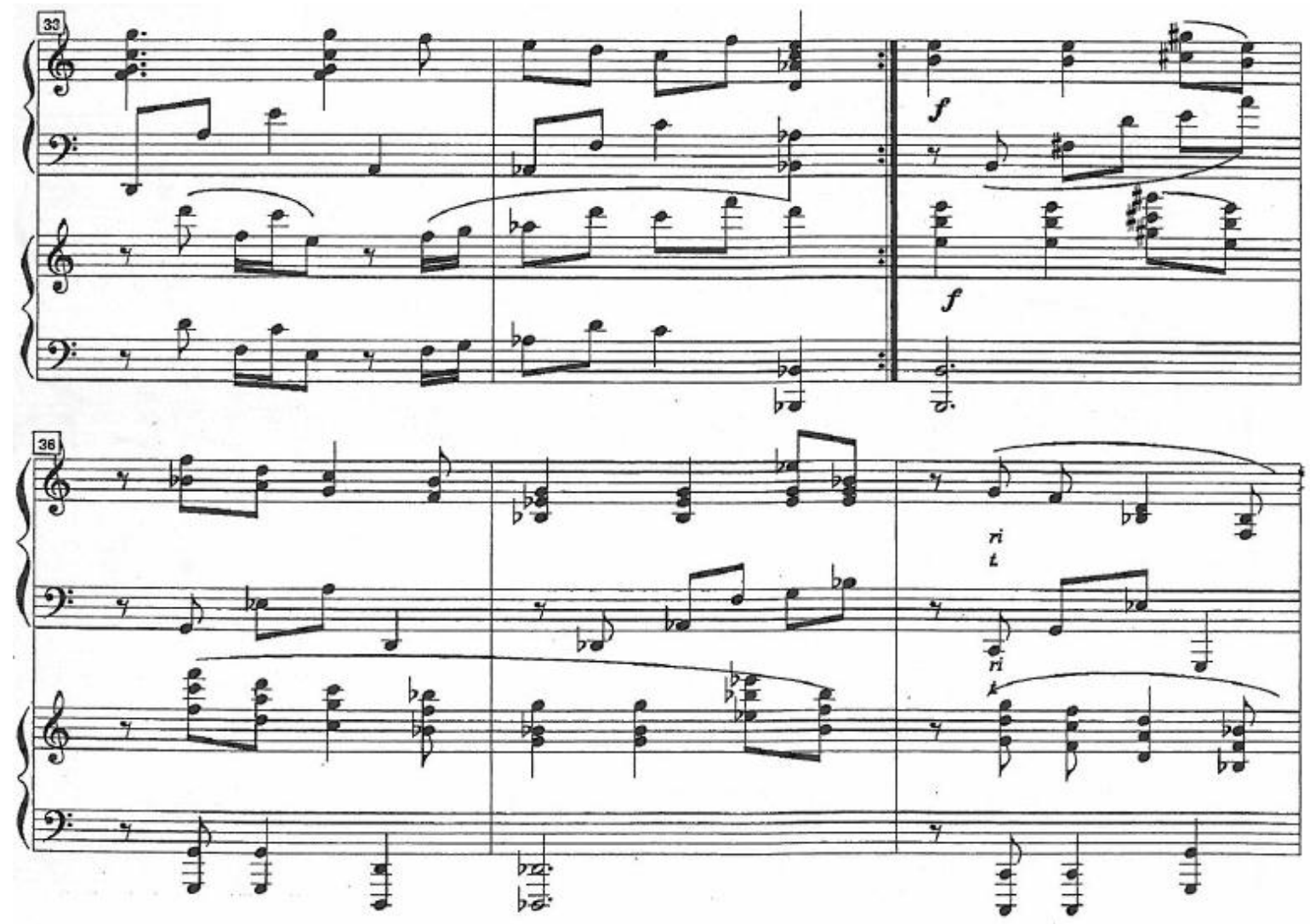

A passage with hand crossings and syncopation in Piano I and clearly articulated rhythmic motives in the right hand of Piano II (mm. 44-46) and its inversion (mm. 47-50), could be studied in a similar way, this time isolating both left hands or both right hands (see Example 8.4). This pattern will repeat until measure 62. 
Example 8.4 Germán Darío Pérez, Dospianazo No. 1, mm. 47-50.

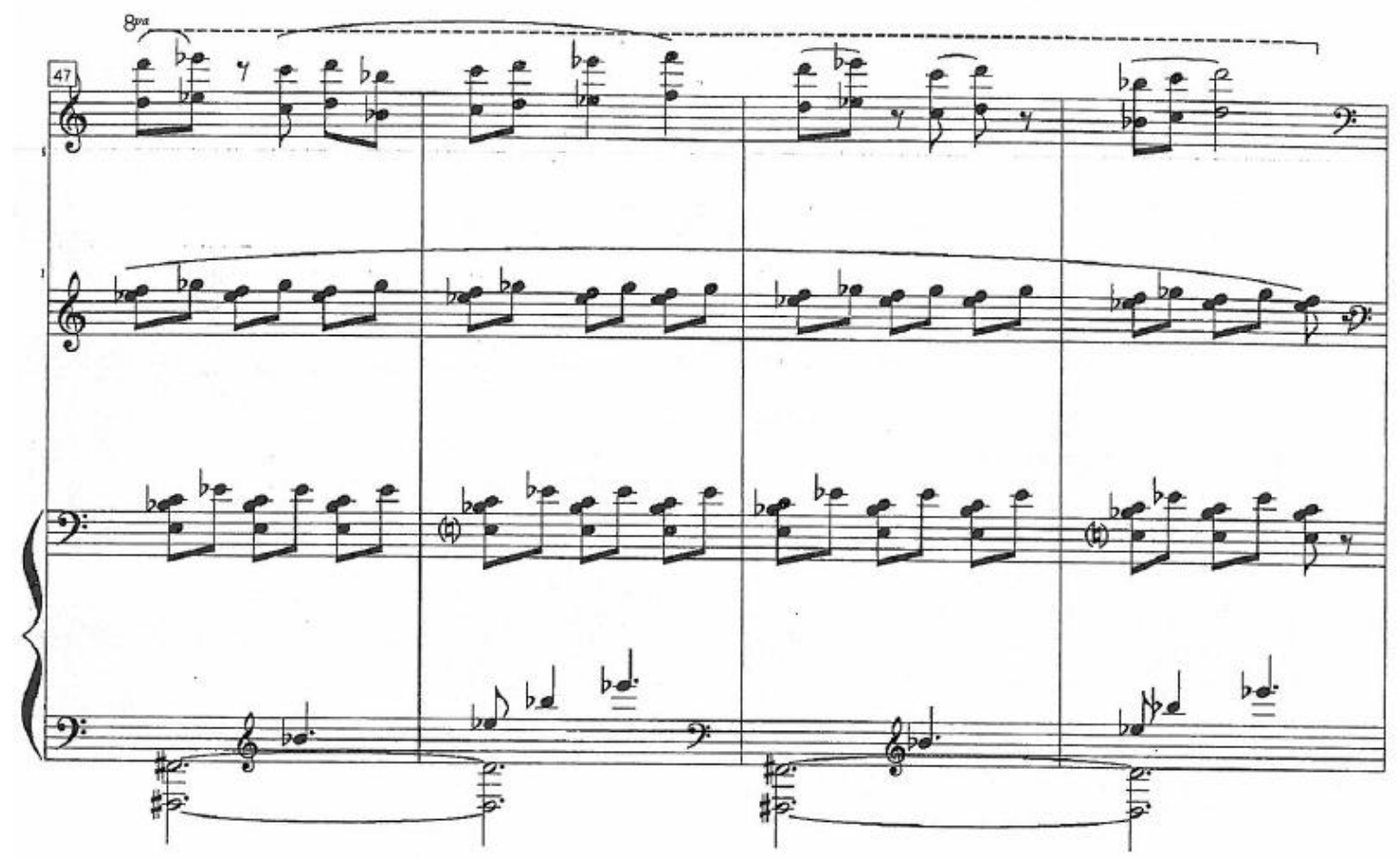

The pianists must be aware of the transition to the guabina rhythm in measure 65 .

Although this is not a complicated rhythm, it needs a particular shaping. As the texture thickens in this section, the balance should be observed even more carefully (see Example $8.5)$. 
Example 8.5 Germán Darío Pérez, Dospianazo No. 1, mm. 63-68.

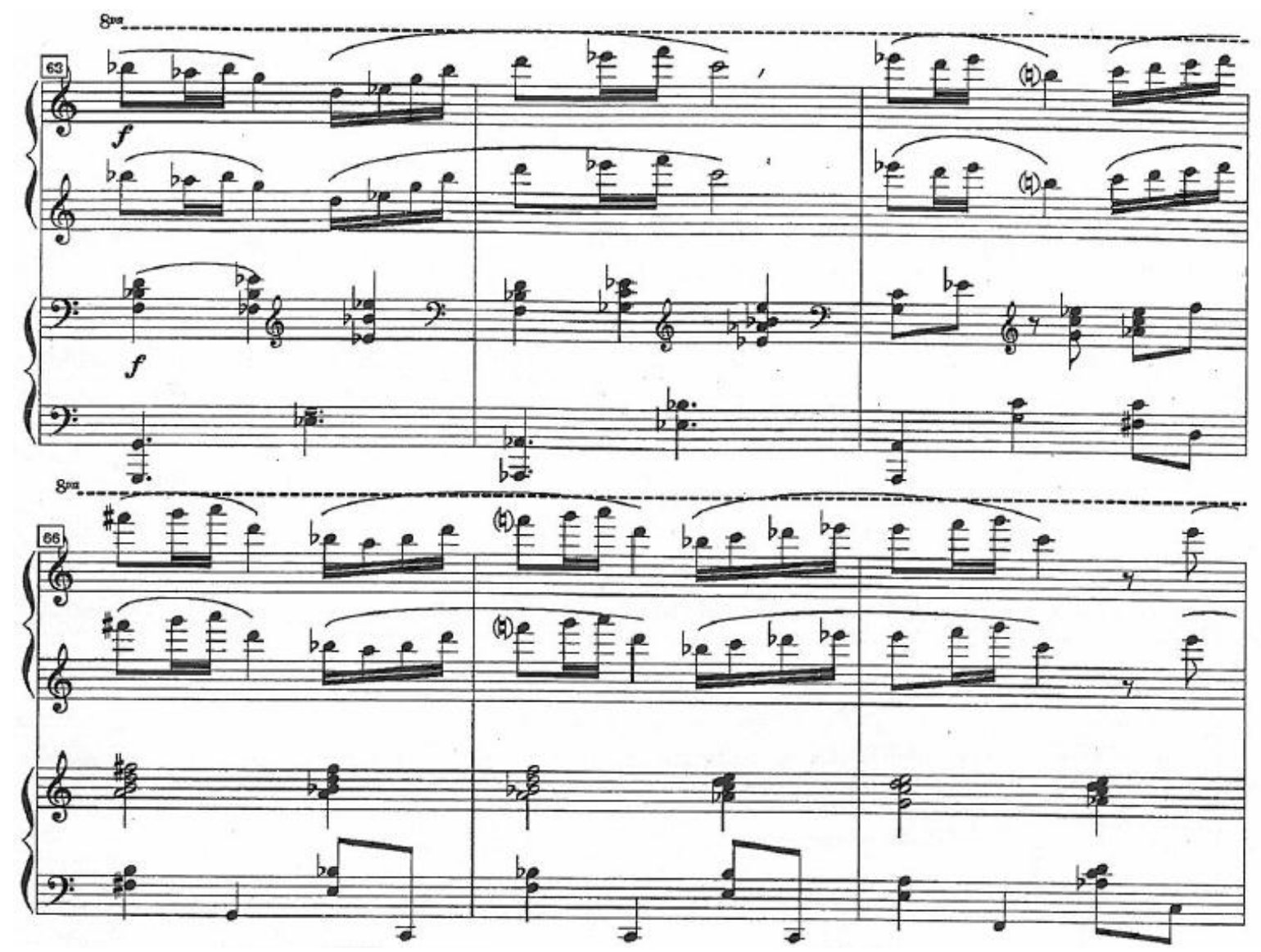

It is very important to establish the dolce espressivo character of this pasillo starting at measure 81 . The melody and the accompaniment marked dolce in the piano II, are beautifully ornamented by a sixteenth-note passage, marked delicatissimo, in the high register in the right hand of Piano I. The atmosphere here should be contrasting and gentle. The roles are inverted in measure 86 (see Example 8.6). 
Example 8.6 Germán Darío Pérez. Dospianazo No. 1, mm. 81-86.

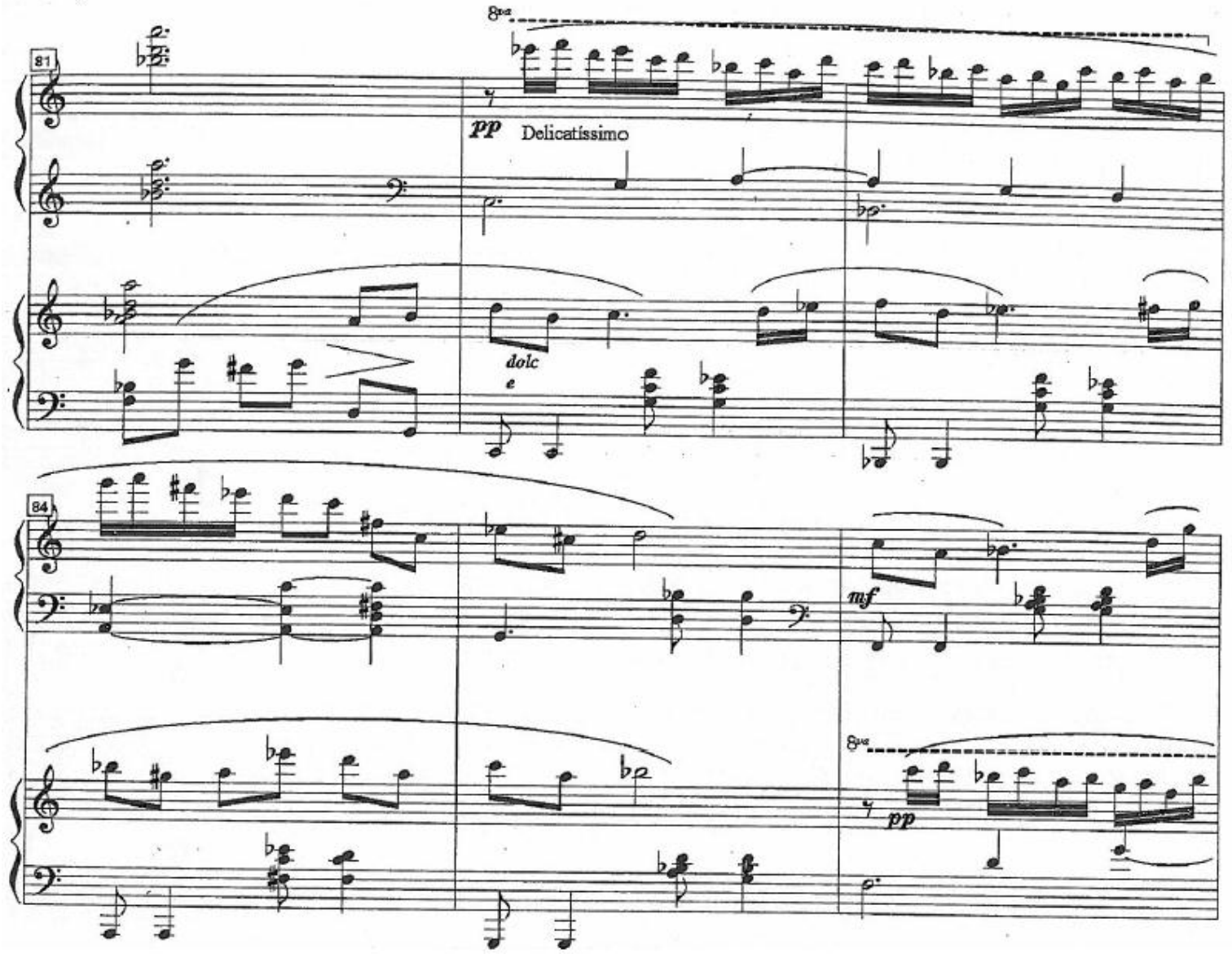

Rhythmic precision and careful use of the pedal are required starting at m. 99, the reason being that in this section both instruments are playing in the low register (Example 8.7). 
Example 8.7 Germán Darío Pérez, Dospianazo No. 1, mm. 99-102.

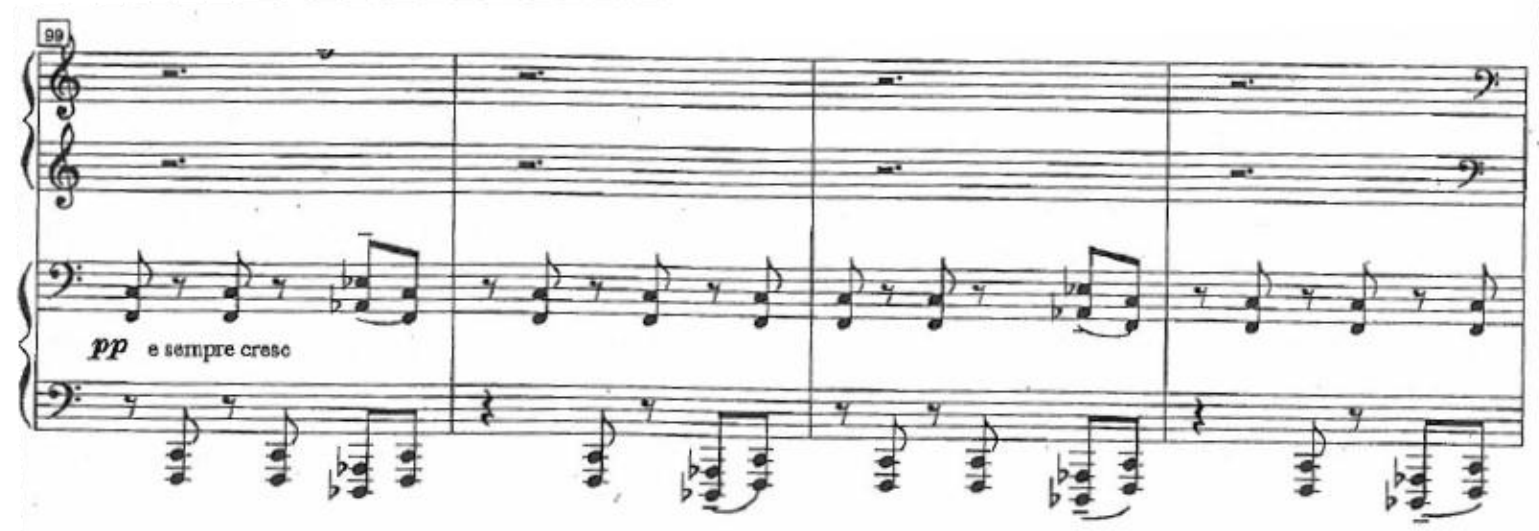

Big climaxes in this piece $(\mathrm{mm} .96-98,166-168)$ are achieved by the use of an interesting orchestral tremolo effect with a crescendo towards ff dynamic in both piano parts, using the extreme registers of the instruments (see Example 8.8).

Example 8.8 Germán Darío Pérez, Dospianazo No. 1, mm. 166-168.

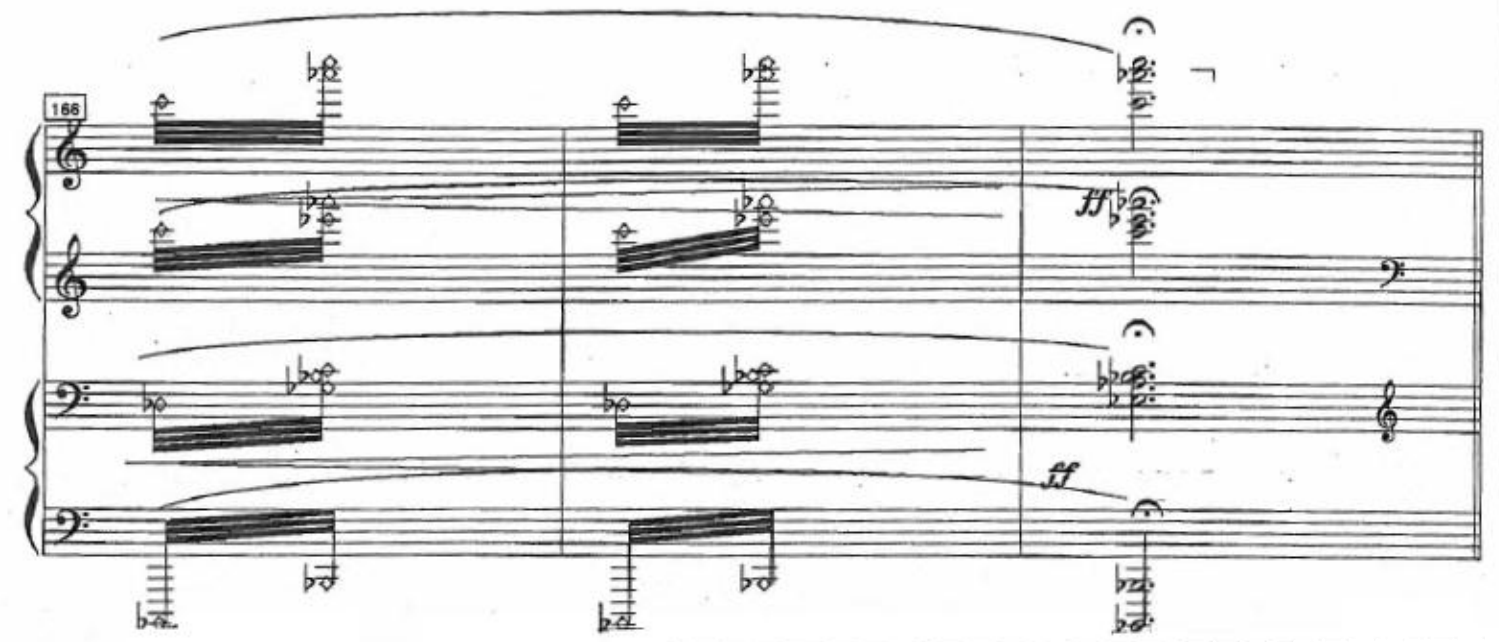


One of the most challenging elements for the ensemble occurs when the two pianos have fast figurations of sixteenth notes in measures 148-150. Practicing in rhythms with the metronome could help the pianists match their sounds with more precision. ${ }^{68}$

Example 8.9 Germán Darío Pérez, Dospianazo No. 1, mm. 148-150.

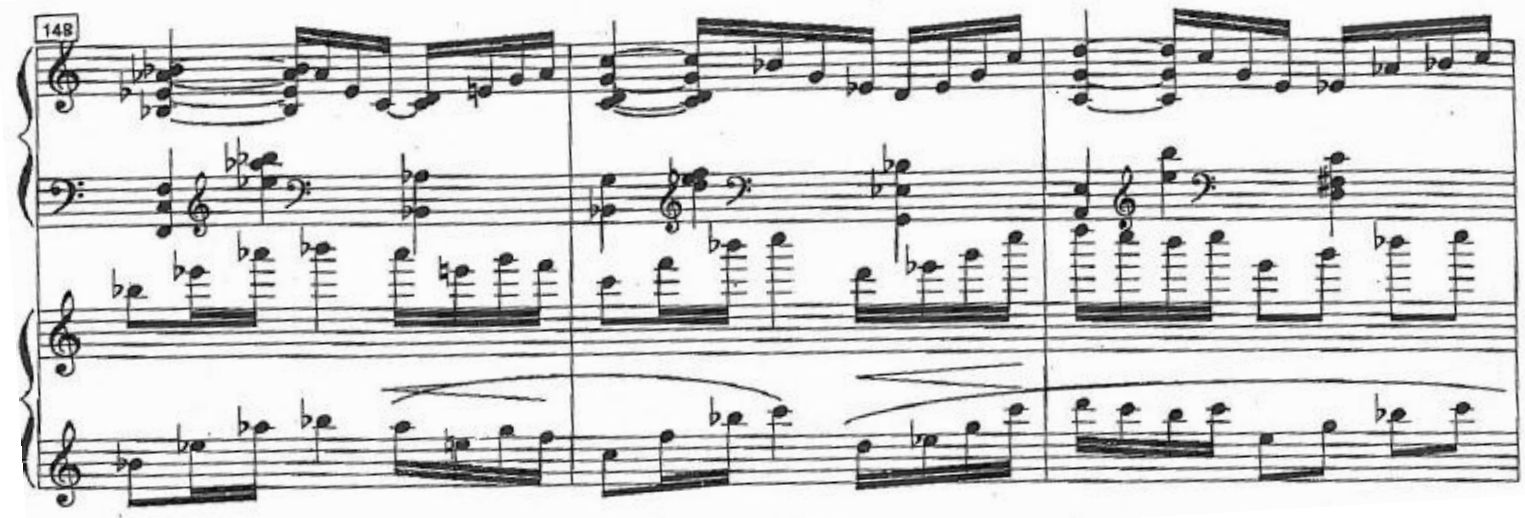

Dospianazo No. 1 exemplifies an interesting incorporation of the ColombianAndean styles with a fluid writing for both instruments. The rhythmic variety of the piece, the complex harmonic language, the contrasting sections, the different moods, the allusions to folkloric styles, and the diversity of the pianistic elements used, constitute a vast source of learning for the collaborative pianist and also encourages further exploration of Latin American pieces for this type of ensemble.

\footnotetext{
${ }^{68}$ Taking the passage of equal note values and playing it in groups of two, three, or four notes with one long note value and the remainder in short values first. Then, shifting the placement of the long value to create a variety of patterns.
} 


\section{Chapter 9}

\section{Conclusions}

The study of contemporary chamber music works with piano by Colombian composers constitutes a useful endeavor for collaborative pianists and other performers, and for educators, musicologists, and other music scholars. Although the pieces examined in this project represent only a small portion of a larger body of worthwhile works, they provide an interesting overview of the immense variety of rhythms, moods, styles, textures, harmonies, and colors present in contemporary Colombian music. The beauty and the complexity of the piano writing in these selected pieces contribute to considering the instrument an equal partner in chamber music.

The pianist will greatly benefit from studying these pieces. Pianistic elements such as: virtuosic writing, percussive qualities, expressive sonorities, driving rhythms, exotic syncopations, varied articulations, flexible tempos, breathing, diction, pedaling, balance, color, and diversity in character constitute the fundamental aspects explored in this repertoire.

Colombia possesses a unique landscape and a vast cultural heritage. It is true that these characteristics have significantly influenced the musical production of Colombian composers, regardless of their age, gender, musical background, and stylistic approach. However, contemporary Colombian composers have not limited their language to folkmusic influences, but have expanded and enriched their palettes with an immense variety of compositional styles. 
This research paper advocates the importance of introducing new multi-cultural works in recital and concert programs around the world. In these difficult times, in which the future of art music is full of uncertainties, it is crucial for musicians to bridge cultures by enriching the musical language with the sounds of different regions. The six pieces studied in this project serve that purpose admirably.

This document also highlights the benefits of studying, performing, and teaching new Colombian chamber-music works. Music educators in the fields of chamber music, clarinet, trumpet, violin, voice, music composition, and piano will have the opportunity to integrate new styles and new repertoire into their classrooms.

Austrian pianist, poet, and author Alfred Brendel has stated that:

A spell of composing experience, even if transitory, will leave its mark on the player's future judgement of works. The question 'How is this piece composed?' will be of benefit in dealing with the other, more customary one: 'How should this work be played?' 69

In this regard, this research project reveals the convenience of establishing strong musical relationships between performers and living composers. It is true that music creation in the $21^{\text {st }}$ century in Colombia is full of fascinating paradoxes and incredible contradictions. Both the composition and the reception of new musical works are culturally conditioned. Since the original meaning and content of pieces change and evolve as time goes on, depending on different circumstances, the success of new works depends not only on their intrinsic qualities, but also on the context in which they are performed, published or recorded. Thus, working with living composers constitutes a great advantage for performers in the present day.

${ }^{69}$ Alfred Brendel, A pianist's A-Z: A Piano Lover's Reader (UK: Faber and Faber Ltd., 2013). 
Although the future of Colombian art music is unknown, the beginning of the $21^{\text {st }}$ century has brought with it an exponential growth in the field of chamber works with piano. There are several contemporary Colombian composers whose pieces in this format were not included in this research paper, but deserve to be studied in detail: The Variaciones for violin, cello and piano (2014) by Juan Antonio Cuéllar (b. 1966), the Divertimento for clarinet, violin, cello, and piano (2008), and the Piano Quartet for violin, viola, cello, and piano (2011) by Diego Vega (b. 1968) are just a few examples. For works like these, this research paper encourages future performances, recordings, and research, which will provide a great service to the world community of musicians. 


\section{Bibliography}

Alvarez, Elissa. "Pride, Place, and Identity: Jaime León's Transcontinental Exploration of Identity through Art Song." Order No. 3575279, Boston University, 2013. https://search.proquest.com/docview/1460489870?accountid=2837

Arango, Diego. "Colombian Piano Music for Four Hands: A Historical Context and Performance Catalog." Order No. 3595076, The University of Iowa, 2013. https://search.proquest.com/docview/1443847325? accountid=2837.

Arias-Esguerra, Mauricio. "Rapsodia Camaleónica: A Concerto for Piano, Trumpet and Chamber Orchestra." Order No. 3505532, Arizona State University, 2012. https://search.proquest.com/docview/1013825416?accountid=2837.

Avendaño, Juan, Sichkov, Sergei, and Arias Mauricio. "Juan Fernando Avendaño.” (CD). Bogotá: 2015.

Baker, Dian. "A Resource Manual for the Collaborative Pianist: Twenty Class Syllabi for Teaching Collaborative Piano Skills and an Annotated Bibliography." Order No. 3241248, Arizona State University, 2006. https://search.proquest.com/docview/305350903 accountid=2837.

Béhague, Gerard, List, George, and Waxer, Lise. "Colombia." In Grove Music Online. Oxford Music Online. Oxford University Press, accessed April 3, 2017, http://www.oxfordmusiconline.com/subscriber/article/grove/music/06137.

Bethel, Leslie. A Cultural History of Latin America: Literature, Music, and the Visual Arts in the 19th and 20th Centuries. Cambridge; New York: Cambridge University Press. 1998.

Botero, Victoria Sofia. "The Art Songs of Jaime León: A Textual and Musical Analysis." Order No. 1498460, University of Missouri - Kansas City, 2011. https://search.proquest.com/docview/893657025 accountid=2837.

Brendel, Alfred. A pianist's A-Z: A Piano Lover's Reader. UK: Faber and Faber Ltd. 2013.

Castro Turriago, Jesus. "Exploring Three Colombian-Andean Folk Style (Danza, Pasillo, and Bambuco): An Analysis and Arrangement of Three Colombian Pieces for Flute and Piano." Order No. 10124211, The University of Southern Mississippi, 2016. https://search.proquest.com/docview/1807430429? accountid=2837. 
Chen, Hsin-Yi. "Infusion of Exotic Influences in Selected Collaborative Piano Repertoire." Order No. 3627552, University of Maryland, College Park, 2014. https://search.proquest.com/docview/1558876373? accountid=2837.

Chester, Pamela Bowen. "A Study of the Life and Wind Music of Blas Emilio Atehortua, Including a Critical Edition and Stylistic Analysis of "Cinco Piezas a Bela Bartok"." Order No. 9827960, University of Northern Colorado, 1997. https://search.proquest.com/docview/304371808? accountid=2837.

Cortázar, Julio. Rayuela. Madrid: Ediciones Alfaguara. 1984.

"Cuatro." In Grove Music Online. Oxford Music Online. Oxford University Press, accessed April 3, 2017, http://www.oxfordmusiconline.com/subscriber/article/grove/music/06925.

Dúo Debussy. “Contrastes.” (CD). Tunja: 2006.

Fisk, Josiah. "The New Simplicity: The Music of Górecki, Tavener and Pärt." The Hudson Review 47, no. 3 (1994): 394-412. doi:10.2307/3851788.

Gomez-Giraldo, Julian. "Analytical and Performance Approach of "Danzas En El Sentimiento Andino" by Luis Antonio Escobar." Order No. 3613630, University of Northern Colorado, 2013. https://search.proquest.com/docview/1508835883? accountid=2837.

Katz, Martin. The Complete Collaborator: The Pianist as Partner. Oxford: Oxford University Press. 2009.

Koorn, Dirk. "Folk Music of the Colombian Andes." Order No. 7800939, University of Washington, 1977. https://search.proquest.com/docview/302868804?accountid=2837.

Lee, Pei-Shan. "The Collaborative Pianist: Balancing Roles in Partnership." Order No. 3415684, New England Conservatory of Music, 2009. https://search.proquest.com/docview/637439700? accountid=2837.

Ligeti, György. Études pour piano, deuxième livre. Mainz; New York: Schott. 1998.

Orduz, Ana Maria. "Integrating Contemporary World Music into our Teaching: Discussion on the Pedagogical Value and Performance Practice of Seven Commissioned Pieces by Four Colombian Composers." Order No. 3461406, The University of Iowa, 2010. https://search.proquest.com/docview/880294134?accountid=2837.

Pérez Salazar, Germán. “Cinco Obras de Cámara.” (CD and Music Score). Bogotá: 2013. 
Posada, Andrés. "La Proyección de la Nueva Música en América Latina: Globalización y Periferia." trans. Javier Camacho. Artes la revista. 5, no. 9. Medellín. Universidad de Antioquia Facultad de Artes. 2005.

Pow, Lauralie Bell. "More than the Mere Notes": Incorporating Analytical Skills into the Collaborative Pianist's Process in Learning, Rehearsing, and Performing Repertoire." Order No. 10154841, University of Miami. 2016. https://search.proquest.com/docview/1836766254? accountid=2837.

Rodríguez-Moreno, Paula. "Vida y Obra del Maestro Jorge Humberto Pinzón Malagón”. Fundación Universitaria Juan N. Corpas. 2016.

Santamaría Delgado, Carolina. "El Bambuco, Los Saberes Mestizos Y La Academia: Un Análisis Histórico De La Persistencia De La Colonialidad En Los Estudios Musicales Latinoamericanos." Latin American Music Review / Revista De Música Latinoamericana 28, no. 1 (2007): 1-23. http://www.jstor.org/stable/4499322.

Schechter, John. "Tiple." In Grove Music Online. Oxford Music Online. Oxford University Press, accessed April 3,

2017. http://www.oxfordmusiconline.com/subscriber/article/grove/music/47557.

Schwartz-Kates, Deborah. "Ginastera, Alberto." In Grove Music Online. Oxford Music Online. Oxford University Press, accessed April 3, 2017, http://www.oxfordmusiconline.com/subscriber/article/grove/music/11159.

Southern, Lia. "A Portrayal of Art Music in Colombia through Four Works for Bassoon." Order No. 3594978, University of Kansas, 2013. https://search.proquest.com/docview/1443788140? accountid=2837.

Sundstrom, Katherine. "Donald Nold and His Contribution to the Emergence of Collaborative Piano." Order No. 10126648, The William Paterson University of New Jersey, 2016. https://search.proquest.com/docview/1808906181?accountid=2837.

Tobo, Mónica. "Una Aproximación a la Obra de Piano de Mario Gómez Vignes.” Universidad Pedagógica y Tecnológica de Colombia, 2008.

Trujillo, Ana Maria. "Colombian Nationalism: Four Musical Perspectives for Violin and Piano." Order No. 3497889, The University of Memphis, 2011. https://search.proquest.com/docview/923630560? accountid=2837.

Varney, John. "An Introduction to the Colombian "Bambuco"" Latin American Music Review / Revista De Música Latinoamericana 22, no. 2 (2001): 123-56. http://www.jstor.org/stable/780461. 
Waxer, Lise. "Salsa." In Grove Music Online. Oxford Music Online. Oxford University Press, accessed March 31,

2017, http://www.oxfordmusiconline.com/subscriber/article/grove/music/24410.

Whittall, Arnold. "phasing." In The Oxford Companion to Music. Oxford Music Online. Oxford University Press, accessed April 2, 2017, http://www.oxfordmusiconline.com/subscriber/article/opr/t114/e5139. 